The

University

of Chicago

Law Review

VOLUME 50 NUMBER 4 FALL 1983

- 1984 by The University of Chicago

\title{
The Emergence of Modern First Amendment Doctrine
}

David M. Rabban†

TABLE OF CONTENTS

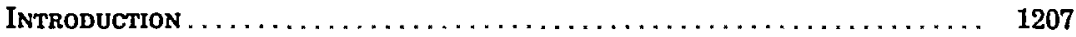

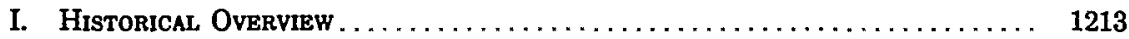

II. The Legislative History of the Espionage Act $\ldots \ldots \ldots \ldots \ldots \ldots \ldots \ldots, 1217$

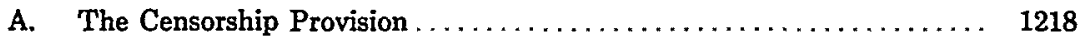

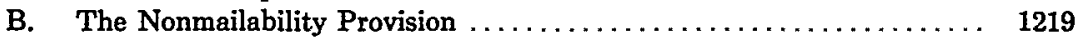

C. The Contrasting Votes on the Censorship and Nonmailability Provisions 1221

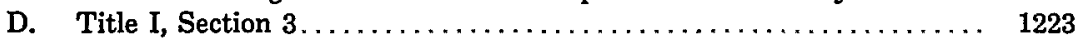

III. Espionage Act Litigation in the Lower Federal Courts . . . . . . . . . . . . . . 1227

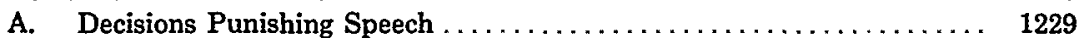

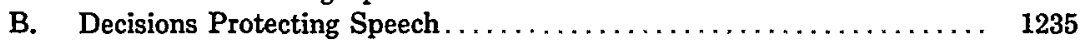

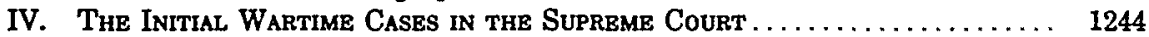

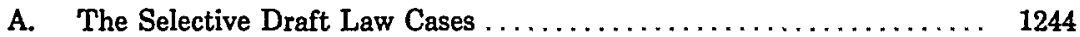

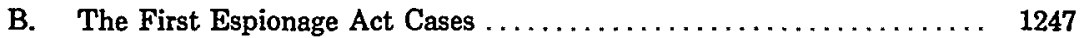

1. The Defendant's Briefs ............................. 1248

2. The Government's Response ...................... 1252

3. The Supreme Court's Decisions ..................... 1257

V. The Doctrinal Origins of "Clear and Present Danger" ............ 1265

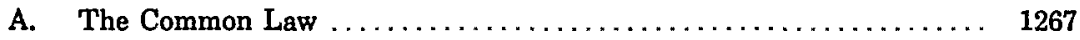

1. Fundamental Themes .......................... 1267

- 1983 by David M. Rabban.

$\dagger$ Assistant Professor of Law, The University of Texas at Austin. For thoroughly reading and thoughtfully commenting on this article, I am grateful to Kent Greenawalt, Jamie Kalven, Stanley Katz, Carol Lee, Norman Levine, Andrew Lipps, Staughton Lynd, and Scot Powe. I also thank the American Bar Foundation for the Fellowship in Legal History that supported my research. 
2. The Relationship Between Community Will and Objective Standards ...................................... 1269

B. The Application of Fundamental Themes to Substantive Law . . . . . 1271

1. Criminal Attempts .............................. 1271

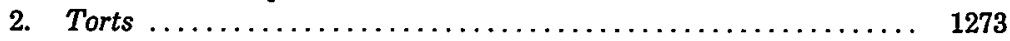

C. Prewar Decisions by Holmes in Attempt Cases................ 1274

D. The Continuity of Holmes's First Espionage Act Decisions ......... 1275

E. The Confirming Evidence of Holmes's Correspondence.............. 1278

VI. Zechariah Chafee, Jr.: The Scholar as Advocate ................. 1283

A. Chafee's Interpretation of the First Amendment ............... 1285

B. Chafee's Rejection of the "Bad Tendency" Test................ 1287

C. Chafee's Misinterpretation of Legal History .................. 1289

D. The Meaning of the Common Law.................... 1290

E. Chafee and the Creation of the Libertarian Myth About "Clear and

Present Danger" ...................................... 1294

F. Chafee as Advocate ............................. 1296

VII. Justice Holmes and the Early Development of the Modern First AmendMENT Tradirion. . . . . . . . . . . 1303

A. The Majority Decisions from Abrams through Whitney......... 1303

B. Holmes's Dissent in Abrams: The Constitutional Divide .......... 1305

C. Explanations for Holmes's Transformation in Abrams ........... 1311

D. Holmes After Abrams ............................. 1317

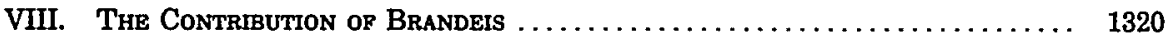

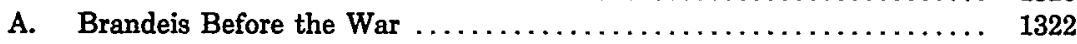

B. Brandeis and Freedom of Expression: 1918-1920 .............. 1326

C. Brandeis and the Unanimous Supreme Court Decisions in the Initial

Wartime Cases ................................ 1329

D. Brandeis and the Elaboration of Libertarian Doctrine ............ 1332

1. Factual and Statutory Analysis .................... 1333

2. Extending the "Clear and Present Danger" Standard ......... 1336

3. Combining "Clear and Present Danger" with Incitement ....... 1337

4. Theoretical Foundations ........................... 1338

5. Identifying Threats to Free Speech.................. 1340

6. Expanding Federal Jurisdiction Over Speech............ 1342

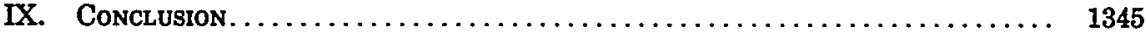

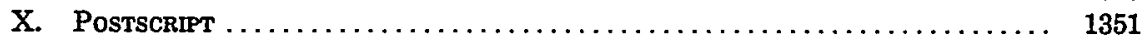




\section{The Emergence of Modern First Amendment Doctrine}

\section{INTRODUCTION}

The emergence of modern first amendment doctrine in the years immediately following World War I is one of the most familiar developments in American constitutional history. Several postwar first amendment decisions by the United States Supreme Court are among the best known of all American cases. ${ }^{1}$ Indeed, the opinions by Justices Holmes and Brandeis in these cases contributed heavily to their reputations as giants of their profession. The articles and book on free speech written between 1918 and 1920 by Zechariah Chafee, Jr., are similarly regarded as classics in the history of American legal scholarship. ${ }^{2}$ The focus on these landmark decisions and scholarly classics, however, has diverted attention from other significant information which requires a reevaluation of the crucial period from the American entry into World War I through the Supreme Court's decision in Whitney $v$. California. ${ }^{3}$

My suspicion that important gaps remained in understanding the development of postwar first amendment doctrine arose as an unexpected by-product of research into judicial and scholarly interpretations of the first amendment in the generation before World War I, a subject previously neglected by most scholars." This research revealed that prewar decisions, including several by Justice Holmes, generally rejected free speech claims, often by refusing even to recognize or address them, and occasionally by relying on the possible "bad tendency" of the speech involved. The

1 See, e.g., Schenck v. United States, 249 U.S. 47 (1919); Abrams v. United States, 250 U.S. 616 (1919); Schaefer v. United States, 251 U.S. 466 (1920); Gitlow v. New York, 268 U.S. 652 (1925); Whitney v. California, 274 U.S. 357 (1927).

Z Z. Chapee, Frebdom op Spezch (1920); Chafee, A Contemporary State Trial-The United States Versus Jacob Abrams et al., 33 HARv. L. Rev. 747 (1920) [hereinafter cited as Chafee, Contemporary State Trial]; Chafee, Freedom of Speech in War Time, 32 Harv. L. Rzv. 932 (1919) [hereinafter cited as Chafee, Harvard]; Chafee, Freedom of Speech, $17 \mathrm{Nzw}$ REpubuic 66 (1918) [hereinafter cited as Chafee, New Republic].

274 U.S. 357 (1927).

- Rabban, The First Amendment in Its Forgotten Years, 90 YaLe L.J. 514 (1981), reports the results of this research. The concluding section describes "the role of the prewar tradition in the early development of modern first amendment doctrine," id. at 579-94, and anticipates some of the conclusions of this article, which is the "separate article" promised then, id. at $581 \mathrm{n} .366$. Because this article is essentially a sequel, I hope the reader will excuse the repeated references to my earlier work. 
postwar opinions by Holmes in Schenck $v$. United States, ${ }^{5}$ Frohwerk v. United States, ${ }^{8}$ and Debs $v$. United States, ${ }^{7}$ and by a majority of the Supreme Court from Abrams $v$. United States ${ }^{8}$ through Whitney $v$. California, ${ }^{9}$ extended this pervasive tradition of judicial hostility to free speech. On the other hand, prewar scholarly writing was remarkably protective and foreshadowed the views of well-known postwar civil libertarians. ${ }^{10}$

This forgotten and complex prewar history makes clear that modern first amendment doctrine, contrary to prevailing assumptions, ${ }^{11}$ did not begin abruptly after Congress passed the Espionage Act $^{12}$ in 1917. Developments during the immediate postwar years, rather than spontaneously creating first amendment doctrine, rapidly transformed it. Significant new perspectives on this transformation emerge from an examination of materials that have been largely overlooked, including the early writings of Holmes, the legislative history of the Espionage Act, the construction of this statute in the lower federal courts, Supreme Court briefs and undeservedly obscure opinions, and a variety of documents and correspondence, much of which remains unpublished.

Chafee's writings, reinforced by the decisions of Holmes and Brandeis and generally accepted for decades, maintain that Holmes established a libertarian standard of first amendment adjudication when he used the phrase "clear and present danger" in Schenck. According to this view, the Supreme Court majority in Abrams replaced Holmes's libertarian approach with the restrictive "bad tendency" theory, thereby provoking Holmes and Brandeis to dissent in order to defend the "clear and present danger" test against this majoritarian heresy. ${ }^{13}$

Recent scholarship has produced a revisionist interpretation of this crucial period of first amendment history. Most strikingly, the revisionists have demonstrated that Justice Holmes moved from a

5249 U.S. 47 (1919).

- 249 U.S. 204 (1919).

7249 U.S. 211 (1919).

250 U.S. 616 (1919).

- 274 U.S. 357 (1927).

so See Rabban, supra note 4, at 559-79.

1I Id. at 516-24.

12 Espionage Act, ch. 30, tit. I, 40 Stat. 217 (1917) (current version at 18 U.S.C. § 2388 (1976)).

13 Z. ChafEe, supra note 2, at 154-55, gives the classic statement of this position. $C$. id. at 94-106. Throughout this article, I use the word "libertarian" to describe expansive or protective interpretations of the free speech clause of the first amendment. This usage should not be confused with the popular ideological meaning of the word. 
restrictive construction of the first amendment in his opinions for a unanimous Court in Schenck, Frohwerk, and Debs, decided in March 1919, to a libertarian position in his dissent in Abrams the following November. While successfully attacking the mythology created by Chafee, Holmes, and Brandeis, the revisionists uncovered some of the doctrinal roots of the "clear and present danger" test. They have also brought needed attention to the relatively libertarian construction of the first amendment during and after World War I by Chafee, Ernst Freund, and Learned Hand, and have speculated about the probable influence of these men on Holmes's changing views between Schenck and Abrams. ${ }^{14}$

" Ragan, Justice Oliver Wendell Holmes, Jr., Zechariah Chafee, Jr., and the Clear and Present Danger Test for Free Speech: The First Year, 1919, 58 J. AM. Hist. 24 (1971), is a recent and comprehensive presentation of the revisionist interpretation. Ragan concentrates on Holmes's transition from a restrictive to a libertarian construction of the "clear and present danger" test between Schenck and Abrams. He traces the origins of "clear and present danger" in Holmes's earlier approach to criminal attempts, analyzes Schenck, Frohwerk, and Debs, describes Chafee's more libertarian interpretation of the first amendment and of "clear and present danger," examines the criticisms of Holmes by Hand and Freund, and concludes with a review of the majority and dissenting opinions in Abrams.

Although Ragan's article is a convincing account of the transformation of "clear and present danger," and focused attention on this crucial topic, earlier scholars had anticipated many of his conclusions. See, e.g., S. Konersky, The Legacy of Holmes and Brandeis 181234 (1956) (observing restrictive original meaning of "clear and present danger," libertarian innovations of the Abrams dissent, and further advances by Brandeis); A. MaikLejoHN, Free Speech and Its Relation to Selp-Government 50-89 (1948) (contrasting Holmes's restrictive approach to free speech, including "clear and present danger," with later sensitivity by Brandeis to first amendment values); Corwin, Bowing Out "Clear and Present Danger," 27 Notre Dame LAw. 325 (1952) (pointing out continuity between Holmes's restrictive prewar decisions and Schenck, Frohwerk, and Debs; "clear and present danger," originally a casual dictum in Schenck, became a constitutional standard only in later dissents by Holmes and Brandeis); Wechsler, Symposium on Civil Liberties, 9 AM. L. ScH. Rev. 881, 882-84 (1941), reprinted in SelECTED Essays on Constitutional LAw, 1938-1962, at 628-29 (Barrett, E., ed. 1963) (asserting that "clear and present danger," a formula with "little positive content," was "seized upon" after Schenck by postwar civil libertarians to attack limitations on freedom of speech).

Three important articles written shortly after Ragan, supra, discuss the development of first amendment theory following World War I. In 1973, The University of Chicago Law Review published a symposium entitled Ernst Freund and the First Amendment Tradition, 40 U. CHI. L. Rev. 235 (1973). In addition to reprinting Freund's critique of Debs from a 1919 issue of The New Republic, Freund, The Debs Case and Freedom of Speech, 19 New RePublic 13 (1919), reprinted in 40 U. ChI. L. REv. 239 (1973), the symposium contains two articles: Kalven, Professor Ernst Freund and Debs v. United States, 40 U. CHI. L. Rev. 235 (1973); Ginsburg, Afterword, 40 U. CHI. L. Rev. 243 (1973). Kalven, stressing the restrictiveness of the "rarely cited" and "shocking" Debs decision, observes that this decision "raises serious question as to what the first amendment, and more especially, what the clear and present danger formula can possibly have meant at the time." Kalven, supra, at 235, 236, 237. Kalven contrasts Debs with Freund's libertarian criticisms and with Hand's "sensitivity to accommodating a tradition of political dissent" in Masses Publishing Co. v. Patten, 244 F. 535 (S.D.N.Y.), rev'd, 246 F. 24 (2d Cir. 1917). Kalven, supra, at 238. Kalven questions 
Yet the revisionists' insights, because they overlook the prewar tradition and subsequent developments, leave much unexplained. Neglected sources allow a comprehensive reinterpretation of the emergence of modern first amendment doctrine. They also provide a broader perspective on more recent developments and on con- . temporary analysis of this fundamental constitutional guarantee. The legislative history of the Espionage Act, contrary to the assertions of the postwar civil libertarians, supported the restrictive decisions of the lower federal courts. ${ }^{15}$ The decisions by Justice Holmes in Schenck, Frohwerk, and Debs derived from his most fundamental philosophical and legal views, expressed earliest and most thoroughly in his seminal book, The Common $\mathrm{Law}_{1}{ }^{16}$ and reflect Holmes's antilibertarian Social Darwinism, which he often translated into external tests of legal liability such as "clear and present danger." Holmes's first Espionage Act opinions were more restrictive than many of the lower court decisions brought to his attention by the defendants' briefs. His correspondence about

Chafee's account of the development of "clear and present danger," but agrees that Holmes, dissenting in Abrams, "was moved to a burst of eloquence about free speech that was to enrich and permanently to alter the constitutional tradition of the first amendment." Id. Ginsburg briefly reviews the correspondence between Hand and Holmes as well as Holmes's reaction to Freund's article. "It is both plausible and intriguing," Ginsburg concludes,

to think that the criticism of Debs in the Freund article and in Hand's correspondence with Justice Holmes throughout the period between Debs and Abrams compelled Holmes to recognize the dangers of Debs's casual approach and influenced his thinking about the value of political speech, even in time of war.

Ginsburg, supra, at 247.

Gunther, Learned Hand and the Origins of Modern First Amendment Doctrine: Some Fragments of History, 27 STAN. L. REv. 719 (1975), establishes and examines in great detail the differences between Hand's objective incitement test for free speech, which focused on the content of the speaker's language, and Holmes's more restrictive approach, which determined the legality of speech by its probable effects or "bad tendency." By analyzing judicial decisions and private correspondence, Gunther makes clear that this doctrinal dispute between Hand and Holmes persisted beyond Holmes's dissent in Abrams, which itself represented a significant libertarian advance over Schenck. Gunther also points out that Chafee, who so effectively promoted the "clear and present danger" test, had a "secret preference" for Hand's analysis in Masses. Id. at 746. In an epilogue, Gunther traces "the belated vindication of Hand's Masses approach," particularly in Brandenburg v. Ohio, 395 U.S. 444 (1969). Gunther, supra, at 750-55.

Bogen, The Free Speech Metamorphosis of Mr. Justice Holmes, 11 HofsTra L. REv. 97 (1982), disagrees with all of these scholars. While conceding that there is "some truth" to their "speculations about Holmes' development of free speech theory over the summer of 1919," he argues "that the different tone of the Abrams dissent is not evidence of a marked change in Holmes' view of free speech, but is rather the product of Holmes' frustration at what he considered the misreading by critics and the public of his position in Schenck." Id. at 99; cf. id. at 163, 173-74. I do not find Bogen's article persuasive.

${ }^{15}$ See infra section III.

16 O.W. Holmes, The Common Law (1938 ed.). 
these opinions confirms the continuing vitality of his early positions. ${ }^{17}$

Chafee was the key figure in the heroic but often disingenuous effort by a few brilliant men to create a libertarian tradition out of this restrictive past. He misrepresented hostile judicial precedents, including the Espionage Act decisions written by Holmes and Brandeis. Chafee also derived an unfounded libertarian meaning from the phrase "clear and present danger."18 Although Holmes had referred to the tendency of speech in affirming convictions in Schenck, Frohwerk, and Debs, and had used the phrase "clear and present danger" only in Schenck, Chafee maintained that Holmes intended these words to make "the punishment of words for their bad tendency impossible."10 Through his misconstruction of "clear and present danger," Chafee was able to reach the entirely erroneous conclusion that Justice Holmes in Schenck agreed with Chafee's own libertarian views.

A variety of historical, intellectual, and personal factors soon led Holmes and Brandeis to join in Chafee's fictions. Holmes's expression of libertarian values in Abrams reveals the extent to which he had become more sensitive to first amendment concerns in the eight months following his opinions for a unanimous Court in Schenck, Frohwerk, and Debs. In writing this dissent, Holmes faced a major problem. Shackled by the heavy weight of restrictive precedents, including his own opinions in the first Espionage Act cases, Holmes had to find legal doctrines to support the values he expressed in Abrams for the first time.

Chafee's Freedom of Speech in War Time, ${ }^{20}$ published between the decisions in Schenck and Abrams, provided a brilliant and convenient solution. The myth Chafee created about the original appearance of "clear and present danger" in Schenck allowed Holmes in Abrams to reject the "bad tendency" theory without repudiating his own prior decisions that had relied so heavily on it. "Clear and present danger," a concept that Holmes developed from a theory of judicial deference to majority will, became, through Chafee's mediation, a libertarian standard of constitutional adjudication in Abrams.

27 See infra section V.E.

1s See infra section VI.E.

19 Chafee, Harvard, supra note 2, at 967.

20 Chafee, Harvard, supra note 2. This issue of the Harvard Law Review arrived at the Library of Congress on August 19, 1919. 
Holmes never became entirely converted to libertarian views. ${ }^{21}$ It was Brandeis who made the major doctrinal advances in the 1920's. Despite having joined in the unanimous decisions in the first wartime cases, including several neglected decisions involving the selective draft law, ${ }^{22}$ and despite having written the opinion in Sugarman v. United States, ${ }^{23}$ the companion case to Schenck, Brandeis later transformed the progressive ideology he had developed before the war into postwar justifications for free speech. ${ }^{24}$

It is a major irony of the first amendment tradition that both Chafee, the most effective advocate of the "clear and present danger" test, and Brandeis, the Justice who did most to add substance to this phrase, seem to have recognized its deficiencies. Instead of a test dependent upon predicting the potential consequences of speech, both seem to have preferred an approach analyzing the meaning of the offending words themselves, the method suggested by some of the prewar commentary on the first amendment and employed by Learned Hand in Masses Publishing Co. v. Patten. ${ }^{25}$ Yet Brandeis, Chafee, and other civil libertarians were not willing to abandon what looked, especially after Abrams, like one of the few hints of tolerance in the history of Supreme Court adjudication of first amendment issues. They tried to make the most of a bleak situation, in part by ignoring prior hostile decisions and in part by "read[ing] . . . the dissenting Abrams eloquence ... . back into Schenck as though it had been there all the time."26

The context in which the words "clear and present danger" first appeared proved to be a continuing constraint on emerging first amendment theory. Only in the late 1950's did the Supreme Court begin to propose alternative approaches to evaluating freedom of expression, and not until its 1969 decision in Brandenburg v. Ohio ${ }^{27}$ had the law "worked itself pure." ${ }^{\text {"28 }}$ Perhaps civil libertarians after World War I made an understandable strategic error in promoting "clear and present danger" as the verbal device with which to incorporate their recently discovered libertarian values into the Constitution. It might have been wiser for them to have

21 See infra section VII.D.

${ }^{22}$ Ruthenberg v. United States, 245 U.S. 480 (1918); Kramer v. United States, 245 U.S. 478 (1918); Goldman v. United States, 245 U.S. 474 (1918).

${ }^{23} 249$ U.S. 182 (1919).

24 See infra section VIII.

2s 244 F. 535 (S.D.N.Y.), rev'd, 246 F. 24 (2d Cir. 1917); see supra note 14.

${ }^{28}$ Kalven, supra note 14, at 238.

27395 U.S. 444 (1969).

${ }^{28}$ Kalven, supra note 14, at 236 n.6. 
followed their best instincts and, like Learned Hand, to have attempted a clean break with a hostile judicial tradition, even if that risked challenging the country's leading jurist and entailed passing up an opportunity to reform the existing tradition from within.

\section{Historical Overview}

The modern civil liberties movement emerged between the congressional debates on the Espionage bill in early 1917 and the Abrams decision in November 1919. Some activity, however, predates this period. In particular, the Free Speech League, a small and informal organization based in New York City, made significant contributions between its founding in 1902 and the beginning of World War I to supporting and publicizing free-speech litigation and values. Members of the League were virtually alone in identifying and defending the principle of freedom of expression in a wide variety of settings-from censorship of information about sex to the "free speech fights" of the Industrial Workers of the World (I.W.W.). Its efforts, which foreshadowed in many respects the later and more effective work of the American Civil Liberties Union (ACLU), have never been adequately understood or appreciated. ${ }^{28}$

In the years before World War I, the people later associated with the origins of the modern first amendment tradition were essentially oblivious, and occasionally even hostile, to free speech activities and values. Roger Baldwin and other founders of the ACLU, Learned Hand, Zechariah Chafee, Jr., Oliver Wendell Holmes, Jr., and Louis D. Brandeis, all lived in a world far removed from the concerns and interests of the iconoclasts in the Free Speech League, and even more distant from the workers and radicals who most often suffered repression. ${ }^{30}$ These postwar civil libertarians, most of whom enjoyed positions of privilege and power, generally had little personal sympathy for, or professional interest in, the radical activity that provoked so many of the free speech cases before the war. Most were in the mainstream of the progressive movement, whose vision of a harmonious society based on scientific principles left little room for dissent. Freedom of expression, to the extent that it was an issue for the progressives at all, was a peripheral one. They saw social problems as symptoms of

${ }^{20}$ See Rabban, supra note 4, at 520-21 n.19. The article on the Free Speech League promised in that footnote is still "forthcoming."

so See D. Johnson, The Challenge to American Freedoms 194-98 (1963). 
a sick society and believed that their scientific program of reform would eliminate the underlying causes. And even within the range of problems they recognized, abuses of economic power loomed much larger to most of them than threats to civil liberties. The progressives concentrated on eradicating the barriers to the utopia they confidently sought. They felt no reason to anticipate dissent in paradise. In an efficient society, as in an efficient machine, friction would no longer be a difficulty. ${ }^{31}$

World War I and its aftermath shattered the illusions of the progressives and millions of other Americans. Many progressives became "tired radicals," 32 but some responded by devoting increased attention to the defense of civil liberties. The transformation of consciousness that created the postwar civil liberties movement did not occur at the same time or in the same manner for all its future leaders. Some of them opposed the war, and threats to the free speech of pacifists and conscientious objectors alerted them to first amendment problems relatively early. Significantly, the ACLU developed from a Civil Liberties Bureau within the

31 R. WIEBE, The SEARch FOR ORDER: 1877-1920, at 154-56, 161, 170 (1967), contains a particularly good discussion of the progressives' analogy between a harmonious society and an efficient machine. Thomas, Nationalizing the Republic, 1890-1920, in B. BALYN, D. DAvis, D. Donald, J. Thomas, R. Wiebe \& G. Wood, The Great Republic 898-99 (1977), effectively reiterates this theme.

P. Murphy, The Meaning of Freedom of Speech 18 (1972), points out that for most progressives "freedom of expression did not rank high in the hierarchy of values." According to Murphy, their own free speech was not threatened. Moreover, they believed that individual freedom would be insured by remedying "serious defects in society" through their program of "social control." Id. D. KENNEDY, OVER HERE 47 (1980), stressing the progressives' concern "for commonality of mind as the indispensable prerequisite for a stable community," identifies their "hopeful premise that men and women in the mass were rational beings, uniformly responsive to reasoned argument and incapable of serious disagreement in the face of scientifically demonstrated facts." Id.

Wiebe and Thomas convincingly maintain that the repression of civil liberties during and after World War I was a natural outgrowth of the progressive movement. Wiebe considers the "fevers of war" part of the more general effort "to discipline American society," $R$. WIEBE, supra, at 287 , and create "a tight national cohesion," id. at 288 . Thomas is more explicit: "The war hysteria fed a progressive appetite for national unity that had gone unchecked by a tradition of civil liberties. The absence of a libertarian concern with protecting basic freedoms, the central weakness in the progressive program, made a domestic war on liberalism all but inevitable." Thomas, supra, at 1024.

32 W. Weyl, Tired Radicals and OTHER PAPERS (1921), captured the reaction of a generation of progressives to the war. The title as well as the concluding pages of an excellent cultural history of the years from 1912 to 1917 underscore the emotional impact of World War I. H. May, The End of American Innocence 393-98 (1964 ed.). See generally C. Forcey, The Crossroads of Liberalism 291-99 (1961); D. Kennedid, supra note 31, at 8992; W. Leuchtendurg, The Perils of Prosperity, 1914-32, at 120-57 (1958); Mowry, The First World War and American Democracy, in War as a Social Instrtution 170, 172-73 (J. Clarkson \& T. Cochran eds. 1941). 
American Union Against Militarism, an organization founded in 1916 by prominent social workers to campaign against President Wilson's drive for military preparedness and to advocate a mediated settlement of the war. Most of the founders of the ACLU, including Roger Baldwin, were pacifists and conscientious objectors before they became civil libertarians. ${ }^{33}$

During the war, the public tended to vilify indiscriminately all dissenters, from socialists and members of the I.W.W. to Christian pacifists. ${ }^{34}$ As a result, these previously separate groups, as well as supporters of the war who became shocked at the extent of private and official oppression, began to recognize their common interest in civil liberties. ${ }^{35}$ The repression during this period was probably no worse in degree than that suffered by many radicals before the war-for example, by the I.W.W. during the 1912 San Diego Free Speech Fight ${ }^{\text {s6 }}$-but it was more widespread. Instead of a temporary and localized outbreak against supposedly dangerous radicals, there was sustained, nationwide repression of even the mildest and most respectable dissenters. The repression became harder for many to ignore, particularly because it struck closer to home. Roger Baldwin, a wealthy Harvard graduate and an eminent reformer who in 1915 had been designated one of the ten most influential citizens of St. Louis, was jailed as a conscientious objector in 1918. His conviction disturbed many influential people in a way the prior imprisonments of anarchists and workers had not..7

For the most part, however, the modern civil liberties movement emerged after the war. Except for people like Chafee, whose teaching responsibilities prompted him to think about free speech issues, and Hand, who had to decide the Masses case the month after Congress passed the Espionage Act, most supporters of the war who became civil libertarians did not do so until after the Ar-

ss See, e.g., D. JoHnson, supra note 30, at 1-25, 197; D. KRNNEDY supra note 31, at 3336; C. Marchand, The Ambrican Peace Movement and Soctal Reform, 1898-1918, at 24061 (1972); Baldwin, Recollections of a Life in Civil Liberties-I, 2 Crv. LrB. RBv., Spring 1975, at 39, 51-55 (autobiographical account). See generally P. MURPHY, WorLd WAR I AND the Origin of Civil Liberties in the United States 153-73 (1979).

st See, e.g., H. MAY, supra note 32, at 387; P. MURPHy, supra note 31, at 22; R. MuRRAY, RED SCARE 166-67 (1964 ed.); Thomas, supra note 31, at 1027. See generally D. KENNEDY, supra note 31 , at $66-83$; R. WEBE, supra note 31 , at 287-90.

35 See D. Johnson, supra note 30, at 196-97; P. MURPHY, supra note 33, at 36 .

s6 See, e.g., M. Dubofsky, We Shall Be All 189-96 (1969); 4 P. Foner, History of the Labor Movement in the United States 194-205 (1965).

${ }^{37}$ See P. MuRPHY, supra note 33 , at 161 . Baldwin, supra note 33 , at $62-65$, relates this incident. The entire article provides a vivid description of Baldwin's background and his early years as a civil libertarian. 
mistice. They were often too involved in the war effort to focus on the domestic abuse of power. The failure of the Versailles Peace Conference "to make the world safe for democracy," along with the extensive violations of the right to free speech and other civil liberties during the "Red Scare" of 1919 , led many to reevaluate the views they had held during the war. A large number discovered that they now shared positions for which opponents of the war had been persecuted and prosecuted. ${ }^{38}$

Others, who did not change their opinions about the war itself, were nevertheless outraged by the repression that followed. For some, the defense of free speech became an active, and often a primary, concern. Several worked hard to protect the rights of the same radicals whose suppression before the war they had largely ignored. ${ }^{39}$ In January 1920 , Roger Baldwin was finally able to overcome the taint of the pacifist origins of the Civil Liberties Bureau and convince a significant number of previously reluctant prowar liberals to join him in establishing the ACLU. ${ }^{40}$ The emergence of modern first amendment doctrine reflected these historical developments in the language of the law.

ss The circle of people associated with The New Republic, which included many of the intellectual leaders of the progressive movement, dramatically illustrates this transformation. See C. Forcey, supra note 32, at 221-315; C. Lasch, The New Radicalism in America 181-224 (1965); Noble, The New Republic and the Idea of Progress, 38 Miss. Valley Hist. REv. 387 (1951).

The shift in John Dewey's views is typical. In opposing "the conscription of thought" in September 1917, Dewey focused on its inefficiency in promoting "social solidarity." He was "not . . . specially concerned" that "liberty of thought and speech" would "seriously suffer ... in any lasting way." Dewey, Conscription of Thought, 12 New REPuBlic 129 (Sept. 1, 1917), reprinted in $2 \mathrm{~J}$. Dewey, Characters and Events 566-70 (1929). Dewey seemed more concerned with the social cost of the victims' resentment than with their rights. Just two months later, however, Dewey recanted. Observing the increase in "bigotry" during the war, Dewey admitted that his earlier article now seemed "strangely remote and pallid." Dewey, In Explanation of Our Lapse, 13 NEw Republic 17 (Nov. 3, 1917), reprinted in 2 J. DEWEY, supra, at 571. Dewey's articles in The New Republic are discussed in C. LASch, supra, at 204-05 and in M. White, Social Thought in America 167-68 (1976 ed.).

39 Several autobiographies by and biographies about postwar civil libertarians indicate the impact of the war on the development of their libertarian views. See, e.g., W. NeLLES, A Liberal in Wartime: The Education of Albert DeSilver 14, 19, 36, 60, 93,96 (1940); 0. Villard, Fighting Years 461 (1939); M. Wreszin, Oswald Garrison Villard 75 (1965); Baldwin, supra note 33, at 40,42-43, 52-53, 59, 67; Chafee, Thirty-Five Years with Freedom of Speech, 1 U. KAN. L. REv. 1, 1-3 (1952); Lash, A Brahmin of the Law: A Biographical Essay, in From the Diaries of Felix Frankfurter 3, 15, 31 (J. Lash ed. 1975); see also C. Forcey, supra note 32 , at $125,178,183,210,314$; C. Marchand, supra note 33, at 385; L. Whipple, The Story of Civil Liberty in the United States v (1927).

to See D. Johnson, supra note 30, at 147. 


\section{The Legislative History of the Espionage Act}

As the likelihood of American participation in World War I increased, lawyers in the Department of Justice became concerned that existing federal laws would be insufficient "to regulate the conduct of the individual during war time."41 These lawyers wanted to repress "political agitation ... of a character directly affecting the safety of the state," particularly "disloyal propaganda" threatening the formation and maintenance of the armed forces. ${ }^{42}$ They assumed that the provisions of the existing Federal Penal Code would be of only limited use. ${ }^{43}$ The eminent legal scholar Charles Warren, who was an assistant attorney general during this period, maintained that speech "[a]dvising, inciting and persuading others to give aid and comfort to the enemy" might itself constitute treason.4 Yet the Department concluded that the strict constitutional provision defining treason and its proof, as well as the absence of any convictions under a federal treason statute over one hundred years old, made the law of treason a fragile instrument "for suppressing or punishing disloyal and

${ }^{4}$ O'Brian, Civil Liberty in War Time, 42 Rep. N.Y. ST. BAR Ass'N 275, 299 (1919); see also id. at 277; Gregory, Suggestions of Attorney-General Gregory to Executive Committee in Relation to the Department of Justice, 4 A.B.A. J. 305, 305-06 (1918); O'Brian, supra, at 277.

42 O'Brian, supra note 41 , at 277,300 .

43 1918 ATr'y GEN. ANN. REP. 16-17, 45 (citing \$\$ 6, 37, and 332); letter from Charles Warren to F.A. O'Connor (May 15, 1916) (National Archives File RG 60, 9-4-25) (citing $\S \S$ 4,6 , and 211). Section 4 prohibited inciting rebellion or insurrection against the United States or its laws. Section 6 prohibited "seditious conspiracy." Section 37 prohibited conspiracies "to commit any offense against the United States." Section 211 declared "obscene" and other "indecent" material "nonmailable," and was amended in 1911 to state that "indecent" material included "matter of a character tending to incite arson, murder, or assassination." Section 332 defined a principal as anyone who counsels or induces the violation of federal law. Act of March 4, 1909, ch. 321, 35 Stat. 1088, 1089, 1096, 1129, 1152 (current version at 18 U.S.C. $\$ \S 2383,2384,371,1461,2$ (a) (1976)) (codifying, revising, and amending the penal laws of the United States); Act of March 4, 1911, ch. 241, § 2, 36 Stat. 1327, 1339 (current version at 18 U.S.C. $\S 1461$ (1976)) (amending $\S 211$ of Act of March 4, 1909, ch. 321).

"Warren, What Is Giving Aid and Comfort to the Enemy?, 27 YALE L.J. 331, 340-43 (1918); memorandum for the Attorney General by Mr. Warren (Jan. 16, 1918) (National Archives File RG 60, 9-12-86) (calling attention to newspaper report of judicial decision sustaining Warren's view "that printed publications, under certain conditions, might constitute treason"). Unfortunately, I have not been able to locate Warren's original memorandum. I assume its reasoning is reflected in his subsequent article.

While Congress was considering the Espionage bill, Warren wrote a congressman that no current statute "provides penalties for treasonable utterances or writings," but that the proposed legislation would cover them. Letter from Charles Warren to Hon. Harold Knutson (April 25, 1917) (National Archives File RG 60, 9-4-110). Warren probably did not want his speculative theory of treason to jeopardize the Espionage bill, which promised firmer grounds for punishing speech. 
hostile acts and utterances."45 Convinced that new federal legislation was needed, the Department drafted the Espionage bill and submitted it to Congress. ${ }^{46}$ Charles Warren was its chief author. ${ }^{47}$

Congress debated the Espionage bill at length during April and May of 1917; hundreds of pages of the Congressional Record are devoted to its consideration. Much of the debate focused on the history and meaning of the first amendment. ${ }^{48}$ Ironically, the section of the bill that ultimately provided the basis for most of the prosecutions hardly received any attention. ${ }^{49}$ Discussion of other proposed provisions, however, gives some indication of congressional views on free speech issues that would soon reach the courts. These debates reveal, contrary to the confident but uninformed assertions of Learned Hand in Masses Publishing Co. $v$. Patten, ${ }^{50}$ and Zechariah Chafee, Jr., in Freedom of Speech in War Time, ${ }^{51}$ that Congress intended the Espionage Act to encourage the restrictive decisions that resulted.

\section{A. The Censorship Provision}

A provision of the bill that would have allowed the President to censor the press $^{\mathrm{s2}}$ dominated congressional discussion and was eventually eliminated by the conference committee. ${ }^{53}$ Several congressmen protested that the first amendment precludes prior restraints, ${ }^{54}$ and objected to delegating vast and unconfined "legislative" power over publications to the President and his

151918 AtT'y Gen. ANn. Rep. 41.

48 Id.

47 The Chairman of the House Committee on the Judiciary stated that Warren "drew practically all" the statutes that became the Espionage Act. 2 Hearings on H.R. 291 Before the House Comm. on the Judiciary, 65th Cong., 1st Sess. 55 (1917) (statement of Rep. Webb) [hereinafter cited as Hearings on H.R. 291]. Attorney General Gregory also referred to Warren's "active part in the framing of the Espionage Act." Letter from T.W.G. to Mr. Warren (Dec. 12, 1917) (National Archives File RG 60, 189676).

${ }^{6}$ See infra notes 54, 77-79 and accompanying text.

49 See infra notes 89-92 and accompanying text.

so 244 F. 535 (S.D.N.Y.), rev'd, 246 F. 24 (2d Cir. 1917); see infra text accompanying notes $164-71$.

s1 Chafee, Harvard, supra note 2; see infra text accompanying notes 507-17.

${ }^{32}$ H.R. 291, 65th Cong., 1st Sess. § 2(c) (1917). A similar provision was included in S. 2, 65th Cong., 1st Sess. § 4 (1917).

ss For discussions of the legislative history of this provision, see Carroll, Freedom of Speech and of the Press in War Time: The Espionage Act, 17 MrcH. L. REv. 621, 622-29, 636 (1919); Edgar \& Schmidt, The Espionage Statutes and Publication of Defense Information, 73 Colum. L. REv. 929, 946-66 (1973). Both articles focus on the defeated "censorship" provision.

s4 See, e.g., 55 Cong. Rec. 779, 2118-19 (1917) (statements of Sen. Borah), 2004-05 (statement of Sen. Ashurst). 
subordinates. ${ }^{55}$ More particularly, they pointed out that the government officials most likely to enforce this provision would naturally be inclined to censor legitimate public criticism as unfair, seditious, and of benefit to an enemy. ${ }^{56}$ Several congressmen also suggested that the existing law of treason would be sufficient to punish newspapers which published information aiding an enemy, the danger that the "censorship" provision was designed to prevent. ${ }^{57} \mathrm{~A}$ proviso precluding restrictions on "any discussion, comment, or criticism of the acts or policies of the Government and its representatives, or the publication of the same"ss did not allay concern about the potential abuse of official discretion. ${ }^{58}$ Nor did an early conference report, which modified the original language of the bill by specifically defining the categories of nonpublishable information and by allowing the President to permit publication of otherwise illegal material deemed "not useful to the enemy." House instructed the conferees to strike the entire censorship provision, ${ }^{61}$ and Congress passed the Espionage Act without it.

\section{B. The Nonmailability Provision}

Congressmen raised similar concerns while debating a provision that proposed to expand the authority of postmasters to declare objectionable publications "nonmailable." A law already on the books, popularly known as the Comstock Act, allowed postmasters to exclude "obscene" and "indecent" publications; ${ }^{62}$ the initial version of the Espionage bill proposed to add to the nonmailable list publications of "treasonable or anarchistic character"6s or in violation of the bill's other provisions. ${ }^{64}$ Congressmen

ss See, e.g., id. at 1751 (statement of Rep. Chandler); see also id. at 784 (statement of Sen. Brandegee), 1712 (statement of Rep. Dillon).

so See, e.g., id. at 2119 (statement of Sen. Borah), 781-82 (statement of Sen. Lodge).

${ }^{87}$ See id. at 1766 (statement of Rep. Thomas); see also id. at 781 (statement of Sen. Lodge), 2008 (statement of Sen. Walsh).

so Both the Senate and House bills contained this proviso. Id. at 2109 (Senate bill), 1813 (House bill). The House Committee on the Judiciary acknowledged the "broad powers" given to the President, but stressed its confidence that he "will not abuse this authority." The Committee added that the proviso, although "hardly necessary," was included to calm "the public and the newspaper fraternity." H.R. REP. No. 30, 65th Cong., 1st Sess. 10 (1917).

See, e.g., 55 Cong. Rec. 1813 (1917) (statement of Rep. Chandler).

0 H.R. REP. No. 65, 65th Cong., 1st Sess. 3 (1917) [hereinafter cited as RePoRT No. 65]; see id. at 19 ("statement of the managers" on modification of $\S 4$ ).

61 H.R. ReP. No. 69, 65th Cong., 1st Sess. 19 (1917).

${ }^{62}$ Act of March 3, 1873, ch. 258, § 2, 17 Stat. 598, 599 (current version at 18 U.S.C. $\S$ 1461 (1976)).

${ }^{63}$ H.R. REP. No. 30, 65th Cong., 1st Sess. 9 (1917). 
protested that these provisions would confer unprecedented and unreviewable "autocratic power" upon the Postmaster General ${ }^{65}$ and could be used to ban "perfectly inoffensive and harmless" publications $\mathrm{s}^{68}$ on virtually any subject of "political, social, and industrial life." archistic" publications, which was inserted after the Post Office Department sent the members of the House Committee on the Judiciary some "horrible" samples, ${ }^{68}$ would be especially subject to administrative abuse because it could be interpreted so broadly. ${ }^{69}$ But the term "treasonable" also caused concern. "A whole lot of people here and elsewhere," warned one representative, "seem to think that if a man does not agree with you he is a traitor and is guilty of treasonable utterances."

Remarkably, even vociferous opponents of the nonmailability provision conceded throughout the lengthy congressional debates that a variety of publications should not be circulated. They agreed, for example, that it would be desirable to exclude from the mails socialist publications advocating opposition to the war and mass resistance to the draft. But they believed that no statute could be so limited. Any nonmailability provision, they feared, would allow postmasters to exclude "legitimate" publications as well, thereby producing "a far greater evil than the evil which is sought to be prevented."

H.R. 291, 65th Cong., 1st Sess. § 1101, 55 Cong. Rec. 1820 (1917).

os 55 Cong. Rec. 1836 (1917) (statement of Rep. Stafford).

6o Id. at 3138 (statement of Rep. Crosser).

${ }^{67}$ Id. at 1871 (statement of Sen. Cummins).

es Id. at 1595, 1821 (statement of Rep. Webb).

co See, e.g., id. at 1820-24.

${ }^{70}$ Id. at 1822 (statement of Rep. Mann). Senator Hardwick tried to meet some of the objections to this provision by suggesting the deletion of any reference to the "character" of words. "Something that would not be accounted treason," he reasoned, could plausibly be considered "of a treasonable character." He therefore proposed an amendment replacing the original language with a prohibition against mailing publications "advocating or urging treason, insurrection, or forcible resistance to any law of the United States." Id. at 2056. The conferees accepted this amendment after the Senate passed it, RkPORT No. 65, supra note 60, at 21, and Hardwick's language became part of the Espionage Act. Espionage Act, ch. 30, tit. XII, § 2, 40 Stat. 217, 230 (1917) (current version at 18 U.S.C. $\$ 1717$ (a) (1976)). As a response to congressional concerns about unreasonable searches, the final act also restricted access to unopened mail. Id; see, e.g., 55 CoNG. REc. 2067-71 (1917).

${ }^{71}$ E.g., 55 Cong. REc. 2062 (1917) (statement of Sen. Thomas). Senator Borah made this point concretely. He shared Senator Overman's hostility to a publication that called every national flag a symbol of bondage and oppression, and characterized a recruitment inscription as a device to obtain "food for the cannon." But he countered this example with "another from the opposite extreme," pointing out that a New York official had censored the fourth verse of "The Star-Spangled Banner" because it might offend England, an ally during the war. Id. at 1869 . Borah complained that the proposed statute would not force 
It is conceivable that some congressmen withheld reservations about suppressing various antiwar publications in order to oppose the nonmailability provision on grounds that would be more appealing to the majority of their colleagues. But many critics of this provision made clear their view that such publications should not be protected by law. These critics simply suggested that expanding the traditional list of nonmailable publications was a dangerous, unnecessary, and disingenuous method. They claimed that the bill was too limited as well as too broad: it threatened legitimate publications without reaching truly objectionable speech that did not circulate through the mails. As in the debates over the censorship provision, ${ }^{72}$ several critics suggested that socialist and I.W.W. antiwar propaganda, whether written or spoken, should be punished as treason. ${ }^{73}$ And if the law of treason proved inadequate, one congressman reasoned, it would be better to let "these scurrilous Industrial Workers of the World . . . go scot free and continue to libel, slander, and strike at this Government" than to "harrass [sic] well-meaning and upright newspapers."?4

Opposition to the nonmailability provision, therefore, did not constitute resistance to the suppression of radical speech. Yet even these limited objections failed to convince a majority of Congress. The Senate easily defeated two motions to strike this section, ${ }^{75}$ and neither house limited the discretion of the Post Office Department.. ${ }^{78}$

\section{The Contrasting Votes on the Censorship and Nonmailability Provisions}

Why did Congress, despite several similar objections to both provisions, grant broad censorship authority to the Post Office Department while denying it to the President of the United States? To a certain extent this anomaly can be attributed to legal and historical factors. Although the exclusion of publications from the mail could effectively prevent circulation, it did not constitute an actual prior restraint. The censorship provision, by contrast, expressly prohibited publication. This distinction may have more for-

postmasters to distinguish between these very different publications. Id.; see id. at 2062 (statement of Sen. Borah).

72 See supra text accompanying note 57.

7s See, e.g., 55 Cong. REc. 1603-04 (1917) (statement of Rep. Johnson).

${ }^{74} I d$. at 1758 (statement of Rep. Johnson).

${ }^{76}$ Id. at 2072 (motion defeated 39-28), 2269-70 (motion defeated 52-29).

26 Espionage Act, ch. 30, tit. XII, 40 Stat. 217, 230 (1917) (current version at 18 U.S.C. 
mal than practical significance, but the debates reveal that many congressmen considered the Blackstonian prohibition against prior restraints the cornerstone of first amendment protection. ${ }^{77}$ Moreover, as defenders of the nonmailability provision pointed out to its critics, Congress had already given the Post Office Department power to exclude obscene and other "indecent" matter from the mail. ${ }^{78}$ Several Supreme Court decisions had upheld this statute against first amendment challenges. ${ }^{79}$ Extending the list of nonmailable publications could have seemed a much less threatening departure than a law permitting censorship.

Yet these explanations, however convincing, do not fully account for the contrasting votes. As the debates on the nonmailability provision indicate, a more pragmatic consideration motivated Congress. Although many were concerned about protecting the free speech of most citizens and newspapers, almost all appeared willing, and often eager, to restrict and punish the more extreme antiwar statements by radicals. ${ }^{80}$ The censorship provision would have allowed the President to forbid the publication of information on matters relating to the military and to national defense. ${ }^{81}$ The prohibition would have attached to the information, not to the style or tone of its presentation. The President's discretion to determine what information would be "useful to the enemy" might have allowed some selectivity in enforcement, ${ }^{82}$ but the focus on specified subjects endangered all publications. This provision could have prevented a major daily newspaper from publishing a thorough factual report on the armed forces, but could not have restrained a general socialist attack on the war as an imperialist adventure that workers should resist. The nonmailability provision, by contrast, referred to the language of the publication rather than to the information published. Despite the faults identi-

77 See supra note 54. The Supreme Court, in an opinion written by Justice Holmes, had accepted Blackstone's views as the constitutional rule. Patterson v. Colorado ex rel. Attorney General, 205 U.S. 454, 462 (1907); see 4 W. Blackstone, Commentaries *150-51.

${ }^{73}$ See, e.g., 55 Cong. REc. 1836 (1917) (statement of Rep. Mann), 2057 (statement of Sen. Sterling).

${ }^{79}$ See, e.g., In re Rapier, 143 U.S. 110, 133-35 (1892); Ex parte Jackson, 96 U.S. 727, 736-37 (1877). Rabban, supra note 4, at 526-29, discusses the briefs and decisions in these and related cases. It is revealing that counsel in Rapier warned that the reasoning of decisions prohibiting lottery advertisements from the mail could be used by a governing party "to silence the journals of its adversaries" by enacting a law that all utterances hostile to " "public interest and morals' . . . should be excluded from the mails." Id. at 527.

${ }^{80}$ See supra text accompanying notes 71-73.

81 See supra text accompanying notes 57-60.

${ }^{82}$ See 55 Cong. Rec. 2094-95 (1917) (statement of Sen. Husting). 
fied by its opponents, it was a more suitable tool to reach those antiwar statements that had few defenders in Congress. Under this provision, a heated socialist or I.W.W. publication could be interpreted as advocating treason or resistance to law even if it contained no sensitive facts about the military.

Representative London, a socialist from New York, observed during the congressional debates that the censorship provision posed "a menace to freedom of press, of the big paper," but that the nonmailability provision "is a menace to all."83 $\mathrm{He}$ considered the expansion of postal power "an attack on the liberties of the little fellow, of the helpless man, of the defenseless man, and not on the powerful newspapers." ${ }^{\text {"44 }}$ According to London, the Post Office would not interfere with the big newspapers, which "owned the country," had "plenty of champions here," and generally supported the President. ${ }^{85}$ Instead, he feared that postmasters, like many speakers in Congress, would "attack certain utterances as treasonable which were nothing more than a protest against war."88 London urged his colleagues who had spoken out so strongly against the censorship provision as a violation of free speech to oppose the nonmailability provision as well. ${ }^{87}$ The daily newspapers may not have "owned" the country, and advocates of antiwar views may have been in greater danger than simply any "little fellow," but London's observations were essentially correct. Indeed, it is hard to avoid the conclusion that Congress rejected his advice precisely because it agreed with his analysis. The evidence of the debates suggests that the majority wanted to restrict antiwar speech it considered dangerous, while protecting the major newspapers and other nonthreatening expression. It is unlikely that Congress trusted the postmasters more than the President; the majority simply viewed the nonmailability provision as a better way to enforce its judgment about the appropriate wartime boundary between protected and unprotected speech.

\section{Title I, Section 3}

Federal officials invoked the nonmailability provision in several prosecutions, most notably in Masses Publishing Co. v. Pat-

\footnotetext{
ss Id. at 1779 .

s4 Id. at 1780.

ss Id.

so Id.

s2 Id.
} 
ten, ${ }^{88}$ an early and particularly important case. The overwhelming majority of Espionage Act cases, however, arose under title I, section $3 .^{89}$ Between 1917 and 1919, hundreds of jury instructions and federal court decisions interpreted its language: ${ }^{00}$

Whoever, when the United States is at war, shall willfully make or convey false reports or false statements with intent to interfere with the operation or success of the military or naval forces of the United States or to promote the success of its enemies and whoever, when the United States is at war, shall willfully cause or attempt to cause insubordination, disloyalty, mutiny, or refusal of duty, in the military or naval forces of the United States, or shall willfully obstruct the recruiting or enlistment service of the United States, to the injury of the service or of the United States, shall be punished by a fine of not more than $\$ 10,000$ or imprisonment for not more than twenty years, or both. ${ }^{91}$

Almost every word defining these offenses turned out to have crucial significance in subsequent litigation, but just a few congressmen referred to this provision during the entire debate about the Espionage bill. ${ }^{92}$

Senator Cummins made sustained criticisms of an earlier version of title I, section 3 . He objected to the section in the Senate bill that punished "[w]hoever, in time of war, shall, by any manner, spread or make reports or statements, or convey any information, with intent to cause disaffection in or to interfere with the operations, or success of, the military or naval forces of the United States ....".93 He emphasized that he had no qualms about the next clause of the provision, which punished false reports ${ }^{24}$ "calculated to cause such disaffection or interference." Nor did he oppose criminal sanctions for true statements intended to interfere with the success of the military forces. ${ }^{95}$ Cummins therefore proposed to amend the bill only by striking out the words "cause disaffection in

${ }^{88} 244$ F. 535 (S.D.N.Y.), rev'd, 246 F. 24 (2d Cir. 1917).

${ }^{80}$ See 1919 Atr'y Gen. AN. Rep. 22; 1918 Atr'y Gen. ANn. Rep. 21, 47.

- Many of these jury instructions and decisions are included in the Interpretation of War Statutes Bulletins, published by the Department of Justice between 1917 and 1919. See infra note 108.

91 Tit. I, \& 3.

92 See H. Peterson \& G. Fite, Opponents of War 17 (1957); Carroll, supra note 53, at 641.

is 54 Cong. REc. 3606 (1917); the text of the earlier version is at 3494 .

24 Cummins had already attempted to clarify this clause. Id. at 3494-95.

os Id. at 3606 . 
or to" and "operations, or." tion" could be invoked to punish exposure of military mismanagement and criticism of official policies and acts. ${ }^{97}$ And he stressed that when no American "can make a truthful statement if he has intent to interfere with what is going on in the military world, I think that you are sapping the very lifeblood of a free people." ${ }^{\text {" } 8}$ In response to a colleague's attempted reassurances about the meaning of intent, ${ }^{9 \theta}$ Cummins observed that the law of intent assumes "that one means the thing which naturally flows from his act or word." 100

\section{The Senate defeated Cummins's amendent, ${ }^{101}$ but the House}

os Id.

97 Id. at 3606-07. Cummins observed that if this provision had been the law in England, articles in The Times exposing English military blunders and a speech by Winston Churchill advocating the withdrawal of troops from Eastern Europe would have been criminal. Id. Cummins added that he himself could have been convicted under the "disaffection" standard because he had recently criticized injustices inflicted on American troops sent to the Mexican border. Id. at 3608.

is Id. at 3607 . Cummins made clear that he considered the second part of his amendment, eliminating the words "operation, or" even more important because "every attempt to change a military situation must be construed as an interference with the military operations." Id. at 3608 .

"9 Id. at 3606-07 (statement of Sen. Walsh).

${ }^{100} \mathrm{Id}$. at 3608.

${ }^{101} I d$. at 3613 . The only other congressional discussion of title $\mathrm{I}, \S 3$, grew out of the report of the House Committee on the Judiciary. 1 Hearings on S. 8148 Before the House Comm. on the Judiciary, 65th Cong., 1st Sess. (1917) [hereinafter cited as Hearings on $S$. 8148]; Hearings on H.R. 291, supra note 47. This Committee had held public hearings on the entire bill. The majority of speakers at these hearings were lawyers, professors, and ministers appearing for themselves or on behalf of organizations such as the American Federation of Labor, the American Union Against Militarism, the Emergency Peace Foundation, the Free Speech League, and the Women's Peace Party of America. Jane Addams, John Reed, and Norman Thomas were the most prominent participants. The sole reference to these public hearings in the congressional debates was an inaccurate comment by one Committee member that, with the exception of possibly three or four speakers, the only people who criticized this section were representatives of hoboes and "of people who, to my mind, are worse than anarchists, because they profess to be American citizens and seem to boast of the fact that they do not care to be loyal to their Government." 55 Cong. REc. 1604 (1917) (statement of Rep. Walsh). In striking contrast to the comments during the congressional debates, these speakers focused their objections to the Espionage bill on title I, $\S 3$. Many echoed the concerns expressed by Senator Cummins. The American Union Against Militarism, while stressing its lack of opposition to criminal sanctions for "the witting dissemination of false information," urged that the clause punishing intent to cause disaffection or interference with military operations be limited in application to enlisted men. The Union feared "the indefinite extension of the law to the whole body of citizenry." 1 Hearings on S. 8148, supra, at 6 (statement of Mr. Norman Thomas). One of its representatives even suggested the elimination of this clause, leaving punishment of "sedition among the troops in the field" to military authorities, who had traditionally exercised this power. Hearings on H.R. 291, supra note 47, at 44 (statement of Mr. Charles T. Hallinan). And Gilbert Roe, appearing on behalf of the Free Speech League, maintained that by restricting the 
Committee on the Judiciary, perhaps in reponse to the vigorous criticisms of the term "intent" at the Committee's public hearings, ${ }^{102}$ subsequently deleted the word "disaffection" from a later version of the Espionage bill. The Committee substituted the phrase "insubordination, disloyalty, or refusal of duty" for "disaffection" in the clause punishing whoever "shall willfully cause or attempt to cause disaffection in the military or naval forces." Chairman Webb explained that "disaffection" was overly "broad," "elastic," and "indefinite," and "might ofttimes subject a perfectly innocent person to punishment." ${ }^{103}$ The new wording was intended

offenses of this section to false reports and interference with the success of the armed forces, the legitimate purposes of the Espionage Act could be met without jeopardizing free speech. Id. at 63; see also id. at 10-11 (statement of Mrs. Horace A. Eaton), 39 (statement of Mr. Gilbert E. Roe), 54 (statement of Mr. Arthur E. Holder), 71 (statement of Miss E.G. Balch); 1 Hearings on S. 8148, supra, at 17 (statement of Dr. Robert L. Hale). Indeed, Roe provided the most trenchant and prescient of all criticisms of the Espionage bill by stressing the dangers of the intent requirement in title $I, \S 3$. Cummins had identified this problem in passing, but Roe, drawing on his experience as a lawyer for the Free Speech League, brought out its full implications. Roe observed, as had Cummins, that "you are presumed to intend what are the necessary consequences of your act." The determination of intent, he added, is a matter for the jury, and during a war "you are going to get a conviction any time any United States district attorney asks for it." Hearings on H.R. 291, supra note 47, at 63.

A question from Chairman Webb allowed Roe to illustrate concretely the potential operation of presumptive intent. Webb asked whether a person could be convicted under this clause for a speech made without any member of the military present, but printed in newspapers which ultimately reached the armed forces and caused disaffection. Hearings on H.R. 291 , supra note 47 , at 63 . Roe replied affirmatively. He supported his response by referring to Fox v. Washington, 236 U.S. 273 (1915), a case in which Roe, as a voluntary service to the Free Speech League, represented an editor convicted under a statute that penalized publications tending to "encourage or advocate disrespect for law." Roe reported that he "was never more surprised" than when the Supreme Court, in a unanimous opinion written by Justice Holmes, upheld that statute. The Fox precedent, Roe indicated, substantiated his concerns about the Espionage bill. Hearings on H.R. 291, supra note 47, at 63; see Rabban supra note 4, at 534-36 (discussing Roe's brief and Holmes's decision in Fox).

The members of the Committee did not make extensive comments during the hearings, but several of them distinguished attempts to change the law from advice to resist existing law. See, e.g., Hearings on H.R. 291, supra note 47, at 34-35 (statement of Rep. Caraway) (distinguishing permissible "political agitation" from unlawful advice "to refuse to obey the law"; provision would not prohibit "petitions for changes in laws, or expressing political views with reference to what is wise or unwise"). They maintained that title $I, \S 3$, would and should punish opposition to enlistment. See, e.g., id. at 23 (statement of Rep. Summers) (statement made opposite enlistment meeting, claiming that "a man who went to war now was violating his duty," illegal under proposed provision). Questioning revealed that representatives had very different views on the line between permissible agitation and illegal opposition, prompting one of them to observe "that there is a distinct vagueness among the members of the Committee as to how far this abridgement of speech is going" and to urge more specific wording. Id. at 25 (statement of Rep. Eaton). Others suggested that opponents of conscription should "be very careful as to how far you go" and should get advice from the Attorney General or a district attorney. Id. at 23 (statements of Reps. Carlin and Dyer).

10254 Cong. Rec. 3609 (1917).

10355 CoNG. REc. 1594 (1917). 
to "get the dishonest fellow who deliberately undertakes to spread disloyalty" while protecting the innocent mother who might create disaffection in her soldier son by describing "sad conditions back home." 104 In response to questioning, Chairman Webb maintained that the new clause permitted factual reporting on conditions in army camps as well as criticism of government policies and officials. He also assured a colleague that it would apply only to willfully false statements, and reiterated that the Committee had "guarded" all true speech. ${ }^{105}$ Yet, as Cummins had warned, striking one word did not remove the dangers to free expression envisioned by opponents of the bill.

\section{Espionage Act Litigation in the Lower Federal Courts}

Government attorneys soon began to prosecute antiwar speech. At first, they used various provisions of the Federal Penal Code to reach agitation that seemed to advocate disobedience to the Selective Draft Law, passed by Congress a month before the Espionage Act. ${ }^{106}$ Most of these prosecutions resulted in convictions. ${ }^{107}$ As one federal judge bluntly pointed out, the Selective Draft Law created a different situation; speech that previously would have been considered "merely . . . general discussion" could now be viewed as "inducing persons to violate the law."108 The government also instituted several prosecutions of antiwar speech under the treason statute, despite reservations about its utility. ${ }^{109}$ An early decision substantiated these doubts by holding that

104 Id. at 1594-95.

${ }^{103}$ Id. at 1595 . Congress also reduced the original fines and prison terms, id. at 793, and added the final clause of $\S 3$. Id. at 871 (suggestion of Sen. Lodge); REPORT No. 65, supra note 60, at 19; see also 55 CoNG. REc. 3137 (1917) (short interchange contrasting $\S 3$ with the censorship provision).

${ }^{108}$ Selective Draft Act of 1917, ch. 15, 40 Stat. 76; see 1918 ATT'y GEN. ANN. REP. 45-46; supra note 43 and accompanying text.

1071918 ATT'y GEN. ANN. REP. 46-47; 1917 AtT'y GEN. ANn. REP. 74; see, e.g., Ruthenberg v. United States, 245 U.S. 480 (1918); Kramer v. United States, 245 U.S. 478 (1918); Goldman v. United States, 245 U.S. 474 (1918); Fraina v. United States, 255 F. 28 (2d Cir. 1918); Firth v. United States, 253 F. 36 (4th Cir. 1918); United States v. Stilson, 254 F. 120 (E.D. Pa. 1918), aff'd, 250 U.S. 583 (1919); United States v. Pierce, 245 F. 878 (N.D.N.Y. 1917). But see United States v. Baker, 247 F. 124 (D. Md. 1917) (directed verdict of not guilty).

${ }^{108}$ United States v. Phillips 5 (S.D.N.Y. 1917) (Interp. of War Stat. Bulletin 14). The Justice Department's Interpretation of War Statutes Bulletins are pamphlets containing opinions, rulings, and jury instructions by federal judges in response to prosecutions, during World War I, under the various war statutes. All the bulletins cited here contain jury instructions, and are on file at the Library of Congress.

1081918 ATt'y GEN. ANN. REP. 41-42. 
"mere words, no matter how vilely disloyal . . . , if accompanied by no other overt act than their utterance or publication, cannot be made the basis of a charge of treason." "110 This loss limited the future use of the law of treason, ${ }^{111}$ but it did not deter continued repression of antiwar speech. The Espionage Act replaced the $\mathrm{Pe}$ nal Code and the treason statute as a more effective method of suppressing unwanted "propaganda"112 and of dealing with "disturbing malcontents." 113 The government even managed to prosecute successfully under the Espionage Act the same newspaper editor who had prevailed under the treason statute. ${ }^{114}$ of the

110 United States v. Werner, 247 F. 708, 710 (E.D. Pa. 1918). "Such seditious utterances," the court promptly added, "are misdemeanors at common law, and, of course, properly made statutory offenses; but the point made is they are not treason." Id. The treason clause provides in relevant part: "No Person shall be convicted of Treason unless on the Testimony of two Witnesses to the same overt Act, or on Confession in Open Court." U.S. Const. art. $3, \S 3$, cl. 1.

In Frohwerk v. United States, 249 U.S. 204 (1919), one of the first Espionage Act decisions by the Supreme Court, Justice Holmes rejected the defendants' suggestion "on the one hand that some of the matters dealt with in the Act of 1917 were treasonable and punishable as treason or not at all, and on the other that the acts complained of not being treason could not be punished. These suggestions seem to us to need no more than to be stated." Id. at 210. As Hurst points out, Holmes disposed of the treason claim "with a curtness which does not do justice to its merits." J. Hurst, The Law of Treason in the United States 161 (1971).

In Wimmer v. United States, 264 F. 11 (6th Cir.), cert. denied, 253 U.S. 494 (1920), the Sixth Circuit explained in more detail why it reached the same conclusion as Holmes. According to the court,

it has never been doubted that Congress may punish, under the ordinary rules of prosecution and without trenching upon the constitutional limitation as to treason, acts which are of a seditious nature and tend toward treason, but which are not of the direct character and superdangerous degree which would meet the constitutional test and make them treason; and even more must this be true of words.

Id. at 13.

Yet Hurst suggests, in a frustratingly inconclusive discussion, that the history and the restrictive definition of the treason clause in the Constitution limit the punishment of speech and cast doubt on the constitutionality of the Espionage Act. J. HURST, supra, at 126-66; see also Z. ChaFEE, supra note 2, at 201-03 (suggesting without concluding that the treason clause precludes federal sedition law).

11 See 1918 ATT'y GEN. ANN. REP. 41. Attorney General Gregory interpreted Werner as holding that "the treason statute could not be used against propaganda, however disloyal or dangerous, except in the rare cases where there is available proof that the propagandist is an agent of the enemy." Id. at 42.

${ }^{112}$ Id. at 45. Chafee believed that the conspiracy statutes in the Federal Penal Code would have been sufficient to punish utterances posing "any serious danger to the prosecution of the war." Z. ChafeE, supra note 2, at 41.

1131917 ATT'y GEN. ANN, REP. 75.

124 Compare Schaefer v. United States, 251 U.S. 466 (1920) (affirming conviction of Louis Werner and others under Espionage Act) with United States v. Werner, 247 F. 708 (E.D. Pa. 1918) (overturning treason indictment of Louis Werner). The Department of Justice had urged the United States Attorney who tried and lost Werner to "keep watch on this paper from day to day, carefully examining each issue and keeping a file of same, and bring 
approximately two thousand Espionage Act prosecutions, ${ }^{115}$ the overwhelming majority were brought and won under title I, section 3. ${ }^{116}$

These Espionage Act cases in the lower federal courts extended the prewar tradition of hostility to free speech, often by the familiar technique of relying on the alleged "bad tendency" of language. They also foreshadowed the construction of the Espionage Act by the Supreme Court, including the unanimous opinions by Justice Holmes in Schenck, Frohwerk, and Debs. The few protective opinions emphasized the restrictiveness of the typical decision. Despite the mythology subsequently created by Chafee, these lower court decisions make clear that Holmes's first Espionage Act opinions, like his prewar decisions, were in the repressive mainstream, not the libertarian vanguard, of judicial interpretation of free speech claims.

\section{A. Decisions Punishing Speech}

Federal district judges generally let juries decide as a question of fact whether a defendant's language violated the law. Whatever the offending language, surrounding circumstances, or jury instructions, almost all prosecutions led to guilty verdicts. Some defendants appealed these verdicts, usually without success. Most circuit courts affirmed simply by relying on the general principle that judges in criminal appeals should not overrule jury findings of fact. Many jury instructions virtually precluded acquittals. One

prosecution under the Espionage Act when you believe that the accumulation distinctly shows a pro-German or antiwar propaganda." Letter from John Lord O'Brian to Francis Fisher Kane (April 9, 1918) (National Archives File No. 9-12-86-65).

Dissenting in Schaefer, Justice Brandeis observed that this prosecution reminded him "of the days when men were hanged for constructive treason." 251 U.S. at 493 . He quoted at length from the jury charge, which distinguished the treason clause from the Espionage Act in language strikingly similar to the Sixth Circuit's holding in Wimmer. Id. at 493-94 n.1; see supra note 110 (discussing Wimmer). Brandeis surmised in horror that "the jury may well have believed from the charge that the Espionage Act had in effect restored the crime of constructive treason." Id. at 493.

111919 ATt'y GEN. ANN. REP. 22.

116 See 1918 ATT'Y GEN. ANN. REP. 47. Several works discuss some of these cases. See, e.g., Z. Charge, supra note 2, at 56-66; P. MURPHY, supra note 33, at 198-211 (discussing the few protective decisions); H. PETERson \& G. FrTE, supra note 92, at 140-47, 152-56, 161-66, 170-78, 181-93; Carroll, supra note 53, at 640-60. Z. ChArse, supra note 2, at 388-94, contains an extremely useful appendix listing prosecutions and results in Espionage Act cases. My reports of convictions in the text that follows are taken from this appendix. See also $\mathrm{H}$. PETERSON \& G. FITE, supra note 92, at 353-57 (table of wartime cases, mostly brought under the Espionage Act); National Crvil Liberties Bureau, War-Time Prosecutions and Mob VIOLENCE (1919) (pamphlet containing list of cases compiled from Bureau's correspondence and press clippings). 
judge told the jury that the Espionage Act punished utterances "which are unfriendly and disloyal to the government" or "are of such a character as to bring the Government's efforts into disrepute or to retard them." Statements calculated to have a "disturbing influence" on men eligible for military service, he added, would also violate the law. ${ }^{117}$ Another judge read the Espionage Act as "prohibiting every man from in any manner attempting to weaken ... the forces which the Government has to rely upon in this war" or from otherwise affecting the spirit of the people. The defendant had been charged with interfering with the fundraising efforts of the Red Cross and the YMCA, and the judge instructed the jury that these organizations were among the "forces" that depended upon a "proper spirit."118 In an analogous case of a defendant who claimed that the capitalists' war would make Liberty Bonds worthless, the judge informed the jury that the first amendment "can not be successfully invoked as a protection where the honor and safety of the Nation is involved." who had advised against enlisting until drafted because the United States had entered the war on faulty premises, heard his jury instructed that they had a right to take into account the "feeling on the part of the great majority of the American people that this war must be won; that no other result would be tolerated." ${ }^{120}$ In a similar prosecution against a man accused of falsely stating that the war was designed to produce slavery to financial barons, the judge required the jury to accept the congressional war resolution as reciting well-known historical facts and "as correctly stating the causes" of American participation. ${ }^{121}$ And some judges expressly stated that convictions could be based on a defendant's opinion. ${ }^{\mathbf{1 2 2}}$

Most jury instructions, however, were much more objective. The majority of federal district judges carefully reviewed the law of intent. Based on the traditional principle that intent must be inferred from external manifestations, they repeatedly announced

${ }_{117}$ United States v. Taubert 4-5 (D.N.H. 1918) (Interp. of War Stat. Bulletin 108).

118 United States v. Wallace 5 (S.D. Iowa 1917) (Interp. of War Stat. Bulletin 4); see id. at 9 (objection of counsel for defendant).

119 United States v. Tanner 3 (D. Colo. 1918) (Interp. of War Stat. Bulletin 56).

120 United States v. Wolf 4 (D.S.C. 1918) (Interp. of War Stat. Bulletin 81).

121 United States v. Harper 3 (W.D. La. 1918) (Interp. of War Stat. Bulletin 76).

122 See, e.g., United States v. Binder 5 (E.D.N.Y. 1918) (Interp. of War Stat. Bulletin 126) (if opinions "were calculated to cause the effect prohibited ... then defendant is guilty"); United States v. Weinsberg 6-7 (E.D. Mo. 1918) (Interp. of War Stat. Bulletin 123) (statements expressing opinions and designed to cause "disloyalty and refusal of duty" prohibited); United States v. Frerichs 9 (D. Neb. 1918) (Interp. of War Stat. Bulletin 85) ("mere prophesy, or predictions, may amount to an obstruction"). 
the basic rule that one is presumed to intend the natural and usual consequences of his acts and that all relevant surrounding circumstances should be taken into account. ${ }^{23}$ Like their counterparts before the war, judges often made this point by telling juries to weigh the "tendency" of language in determining its legality. ${ }^{124}$ Many judges pointed out that the Espionage Act punished advocacy of insubordination and obstruction of recruitment, while they stressed that all Americans remained free to express opinions on the war. ${ }^{125}$ Several specifically contrasted legal agitation for repeal of law with illegal advocacy of resistance to law. ${ }^{126}$ Beyond such generalities, however, judges rarely refined these standards in ways that could help a jury determine if a particular defendant's speech violated the Espionage Act.

Some convictions by juries so instructed are not surprising. For example, a jury found a man guilty of attempting to cause insubordination because he told people subject to the draft that he hoped Germany would win the war and that "the best thing they

123 See, e.g., United States v. Nearing 16 (S.D.N.Y. 1919) (Interp. of War Stat. Bulletin 192); United States v. Weist 4-5 (E.D. Mo. 1918) (Interp. of War Stat. Bulletin 169); United States v. Bunyard 9 (E.D. Mo. 1918) (Interp. of War Stat. Bulletin 168); United States v. Prieth 12 (D.N.J. 1918) (Interp. of War Stat. Bulletin 156); United States v. Rhuberg 5 (D. Or. 1918) (Interp. of War Stat. Bulletin 94); United States v. Zittel 4 (W.D. Wash. 1918) (Interp. of War Stat. Bulletin 90); United States v. Henricksen 2 (D. Neb. 1918) (Interp. of War Stat. Bulletin 86); United States v. Mackley 3 (D. Vt. 1918) (Interp. of War Stat. Bulletin 83); United States v. Foster 3, 5-6 (W.D. Wash. 1918) (Interp. of War Stat. Bulletin 78); United States v. Ramp 6 (D. Or. 1918) (Interp. of War Stat. Bulletin 66); United States v. Huhn 5 (D. Wyo. 1918) (Interp. of War Stat. Bulletin 58); United States v. Baltzer 8-9 (D.S.D. 1918) (Interp. of War Stat. Bulletin 3); United States v. Doll 3 (D.S.D. 1917) (Interp. of War Stat. Bulletin 5).

124 See, e.g., Unites States v. Bold 8-9 (D. Or. 1919) (Interp. of War Stat. Bulletin 183); United States v. Equi 23 (D. Or. 1918) (Interp. of War Stat. Bulletin 172); United States v. Wishek 5 (D.N.D. 1918) (Interp. of War Stat. Bulletin 153); United States v. Fontana 6-7 (D.N.D. 1918) (Interp. of War Stat. Bulletin 148); United States v. Pierce 35, 37 (N.D.N.Y. 1918) (Interp. of War Stat. Bulletin 52); United States v. Doll 4 (D.S.D. 1917) (Interp. of War Stat. Bulletin 5).

12s See, e.g., United States v. Nearing 14 (S.D.N.Y. 1919) (Interp. of War Stat. Bulletin 192); United States v. Albers 17 (D. Or. 1919) (Interp. of War Stat. Bulletin 191) (interpreting language of 1918 amendment); United States v. Berger 8-9 (N.D. Ill. 1919) (Interp. of War Stat. Bulletin 186); United States v. Bold 7-8 (D. Or. 1919) (Interp. of War Stat. Bulletin 183) (interpreting language of 1918 amendment); United States v. Elmer 3 (E.D. Mo. 1918) (Interp. of War Stat. Bulletin 171); United States v. Debs 12 (N.D. Ohio 1918) (Interp. of War Stat. Bulletin 155) (interpreting language of 1918 amendment).

${ }^{128}$ See, e.g., United States v. Kornmann 12-13 (D.S.D. 1918) (Interp. of War Stat. Bulletin 89); United States v. Pierce 19-20, 23-24 (N.D.N.Y. 1918) (Interp. of War Stat. Bulletin 52); United States v. Olivereau 6-7 (W.D. Wash. 1918) (Interp. of War Stat. Bulletin 40); see also United States v. Wells 7-8 (W.D. Wash. 1918) (Interp. of War Stat. Bulletin 70) (prosecution under Penal Code); United States v. Isenhouer 15 (W.D. Okla. 1917) (Interp. of War Stat. Bulletin 23) (prosecution under Penal Code). 
. . . could do when in battle would be to put up their hands and let the Germans take them prisoners."127 Another jury convicted an I.W.W. speaker, indicted on similar charges, for advising conscripted men that they "better have a pick and shovel laboring for the working men instead of carrying a gun for the capitalists."128

Yet similar instructions led to convictions for much more innocuous speech. As Gilbert Roe had warned the House Committee on the Judiciary, ${ }^{129}$ juries instructed on the law of intent and tendency typically convicted defendants. Juries often construed as "false statements" claims by defendants that the financial interests of capitalists were responsible for American participation in the war. ${ }^{130} \mathrm{~A}$ jury found a minister guilty of an attempt to cause insubordination because he distributed a pamphlet teaching that Christians should not kill in wars. ${ }^{131}$ Another jury convicted twentyseven "German" farmers in South Dakota, who belonged to the Socialist Party, for conspiring ${ }^{132}$ to obstruct the recruitment service because they petitioned the governor to change his decision exempting entire counties from the draft. ${ }^{133}$

Even instructions unusually sensitive to free speech generally resulted in guilty verdicts. In United States $v$. Equi, ${ }^{134}$ jurors cautioned against being influenced by their personal feelings about the I.W.W. nevertheless found an I.W.W. speaker guilty under the insubordination and obstruction clauses for stating in a public address that the I.W.W. was not fighting for the flag of any country, but for "the red banner that stood for the blood of the industrial workers."13s Juries also returned guilty verdicts after instructions not to convict on the basis of idle gossip" ${ }^{136}$ or speech made "as a result of sudden anger and without deliberation."137

Some judges, in jury instructions and circuit court affirmances of guilty verdicts, gave closer attention than did most of their col-

127 United States v. Rhuberg 2 (D. Or. 1918) (Interp. of War Stat. Bulletin 94).

${ }^{128}$ United States v. Ramp 2 (D. Or. 1918) (Interp. of War Stat. Bulletin 66).

129 See supra note 101.

1so See, e.g., United States v. Kirchner 2 (N.D.W. Va. 1918) (Interp. of War Stat. Bulletin 69); United States v. Pierce 2 (N.D.N.Y. 1918) (Interp. of War Stat. Bulletin 52). See Z. ChafEe, supra note 2, at 388-394, for reports of convictions in these cases.

131 United States v. Waldron 304 (D. Vt. 1918) (Interp. of War Stat. Bulletin 79).

132 Title I, § 4 of the Espionage Act punished conspiracies "to violate the provisions of sections two or three of this title . ..." Espionage Act, ch. 30, 40 Stat. 217, 219 (1917).

133 United States v. Baltzer 1 (D.S.D. 1918) (Interp. of War Stat. Bulletin 3).

13. United States v. Equi 4-5 (D. Or. 1918) (Interp. of War Stat. Bulletin 172).

138 Id. at 4.

198 United States v. Zadeniack 7 (N.D. Ohio 1918) (Interp. of War Stat. Bulletin 143); United States v. Miller 4 (D. Colo. 1918) (Interp. of War Stat. Bulletin 104).

${ }^{137}$ United States v. Krafft 4 (D.N.J. 1917) (Interp. of War Stat. Bulletin 6). 
leagues to the specific language of title I, section 3. Several judges concluded, consistently with the statutory language but contrary to the assurances of Representative Webb during the congressional debates, ${ }^{138}$ that statements need not be false to violate the insubordination and obstruction clauses. ${ }^{139}$ "A presentation of historic facts," one judge emphasized, if "marshalled so as to extol and glorify Germany, and so as to hold up to criticism and reproach Great Britain, with whom our soldiers were to fight and wage this war, might accomplish the results forbidden by the law."140 Judges also construed "obstruct" loosely. ${ }^{141}$ One acknowledged that the obstruction clause, unlike the insubordination clause, did not expressly punish attempts. Yet he concluded that the enlistment and recruitment service could be obstructed without actually being stopped. He therefore told the jury, using a phrase commonly adopted in other instructions, "that obstruction in its broad sense means to hinder, to impede, to embarrass, to retard, to check, to slacken, to prevent, in whole or in part" and even "to render more burdensome or difficult the enforcement and execution of the law."142 In construing all three clauses of title I, section 3, moreover, judges repeatedly observed that the relationship between language and the statutory prohibitions need not be direct ${ }^{143}$ and, more specifically, that the offending speech need not be made in the presence of soldiers. "144 "Can a man who contaminates the

13e See supra text accompanying note 105.

130 See, e.g., Goldstein v. United States, 258 F. 908, 910 (9th Cir. 1919); United States v. Equi 12 (D. Or. 1918) (Interp. of War Stat. Bulletin 172); United States v. Wishek 5 (D.N.D. 1918) (Interp. of War Stat. Bulletin 153); United States v. Binder 5 (E.D.N.Y. 1918) (Interp. of War Stat. Bulletin 126).

${ }^{140}$ United States v. Wishek 5 (D.N.D. 1918) (Interp. of War Stat. Bulletin 153). The judge did concede that the truth of a statement is relevant to determining the intent of a speaker. Id.

${ }^{141}$ See, e.g., Deason v. United States, 254 F. 259, 261 (5th Cir. 1918); Doe v. United States, 253 F. 903, 906 (8th Cir. 1918); O'Hare v. United States, 253 F. 538, 540 (8th Cir. 1918); United States v. Rhuberg 4 (D. Or. 1918) (Interp. of War Stat. Bulletin 94); United States v. Frerichs 4 (D. Neb. 1918) (Interp. of War Stat. Bulletin 85); United States v. Wolf 5-6 (D.S.D. 1918) (Interp. of War Stat. Bulletin 81); United States v. Hitt 6 (D. Colo. 1918) (Interp. of War Stat. Bulletin 53).

${ }^{142}$ United States v. Hitt 6 (D. Colo. 1918) (Interp. of War Stat. Bulletin 53). The decision by the Second Circuit in Masses Publishing Co. v. Patten, 246 F. 24, 38 (1917), may have been the original source for this phrase.

${ }^{143}$ See, e.g., United States v. Equi 11 (D. Or. 1918) (Interp. of War Stat. Bulletin 172); United States v. Stephens 7 (D. Del. 1918) (Interp. of War Stat. Bulletin 116).

${ }^{24}$ See, e.g., Goldstein v. United States, 258 F. 908, 911 (9th Cir. 1919); Coldwell v. United States, 256 F. 805, 809 (1st Cir. 1919); Kirchner v. United States, 255 F. 301, 302-04 (4th Cir. 1918) (citing for support many jury instructions from Interpretations of War Statutes Bulletins); United States v. Weinsberg 7 (E.D. Mo. 1918) (Interp. of War Stat. Bulletin 123); United States v. Miller 4 (D. Colo. 1918) (Interp. of War Stat. Bulletin 104). 
spring at its source," one judge asked, "avoid responsibility because the resulting damage occurs at the mouth of the stream?"145 And the Eighth Circuit held that an indictment under the Espionage Act need not allege the illegal effects of language. For a purely statutory offense, it reasoned, "the words of the statute contain all the ingredients of the offense."146

Judges hearing Espionage Act cases, like their predecessors faced with free speech claims before the war, rarely referred to the first amendment. The few who cited it generally stressed that the Constitution does not provide absolute protection for speech. They listed the traditional exceptions for libel, slander, blasphemy, and obscenity, and emphasized, as had the Supreme Court in a 1904 decision, ${ }^{147}$ that the government's right of "self-preservation" supersedes an individual's freedom of expression. ${ }^{148}$ One judge, for example, reasoned that the first amendment "carries with it no right to subvert the purposes and destiny of the nation."148 Judges also observed that free speech is but one of many equally important rights protected by the Constitution. ${ }^{150}$ As a jury instruction pointed out, the same Constitution that forbids Congress from abridging free speech also grants it power to declare war and raise armies. Neither provision, the judge asserted, could "destroy or break down" the other. He concluded that the Espionage Act, by punishing interference with the war effort without reaching "the proper advocacy of principle within the limitations of the law," appropriately balanced these two constitutional provisions. ${ }^{131}$ Another judge bluntly stated that speech "which in ordinary times might be clearly permissible, or even commendable, in this hour of national emergency, effort, and peril, may be as clearly treasonable, and therefore properly subject to review and repression."162 He therefore upheld the seizure by the government of a film about

14 United States v. Nagler, 252 F. 217, 222 (W.D. Wis. 1918).

${ }_{146}$ Doe v. United States, 253 F. 903, 904-05 (8th Cir. 1918).

167 United States ex rel. Turner v. Williams, 194 U.S. 279 (1904), discussed in Rabban, supra note 4 , at 536 .

148 Id. at 294.

${ }^{148}$ United States v. Motion Picture Film "The Spirit of '76," 252 F. 946, 948 (S.D. Cal. 1917), aff'd sub nom. Goldstein v. United States, 258 F. 908 (9th Cir. 1919).

${ }_{180}$ United States v. Equi 20-21 (D. Or. 1918) (Interp. of War Stat. Bulletin 172); United States v. Stephens 3-4 (D. Del. 1918) (Interp. of War Stat. Bulletin 116).

${ }_{151}$ United States v. Stephens 21 (D. Del. 1918) (Interp. of War Stat. Bulletin 172); see also Doe v. United States, 253 F. 903, 906 (8th Cir. 1918) (stressing war power as constitutional justification for Espionage Act).

${ }_{152}$ United States v. Motion Picture Film "The Spirit of '76," 252 F. 946, 948 (S.D. Cal. 1917), aff'd sub nom. Goldstein v. United States, 258 F. 908 (9th Cir. 1919). 
the Revolutionary War because it portrayed "unspeakable atrocities committed by British soldiers,"153 which might "tend . . . to make us a little bit slack in our loyalty to Great Britain."154

\section{B. Decisions Protecting Speech}

A few decisions demonstrated that it was possible to construe the Espionage Act in ways that protected antiwar speech. A handful of district judges withheld cases from juries, and an equally small number of their colleagues on the circuit courts reversed convictions on appeal.

Judge Learned Hand's opinion in Masses Publishing Co. $v$. Patten, ${ }^{155}$ decided the month after Congress passed the Espionage Act, interpreted it in a way that would have precluded most subsequent convictions under its provisions. The New York Postmaster precipitated the case by invoking the Espionage Act to declare The Masses "nonmailable." According to the Postmaster, antiwar articles and cartoons in The Masses "tended to produce a violation" of all three clauses of title I, section $3 .{ }^{158}$ Gilbert Roe represented the editors who were threatened with the very dangers to free speech that Roe himself had highlighted in his testimony before the House Committee on the Judiciary. ${ }^{167}$

Hand granted the injunction Roe sought against the Postmaster. He treated the clauses of the Espionage Act in order, and began his opinion by reasoning that the "false statements" punished by the first clause referred only to "the spreading of false rumors which may embarrass the military." The government's application of this clause to The Masses constituted an impermissible attempt "to raise it into a means of suppressing intemperate and inflammatory public discussion, which was surely not its purpose." Hand conceded as "unhappily true" that the contents of the magazine might "enervate public feeling at home" and cause "mischievous effects" on the war effort. But he insisted that these tendencies

158 Id. at 947.

ses Id. at 948 .

185244 F. 535 (S.D.N.Y.), rev'd, 246 F. 24 (2d Cir. 1917). Gunther, supra note 14, has afforded Hand's decision the prominence it has long deserved. That article stresses, with convincing support from Hand's correspondence with Holmes and Chafee, that Hand viewed his objective incitement standard as a protective alternative to examining the "bad tendency" or "probable consequences" of language, the approach used by most federal judges, including Justice Holmes, to determine the legality of speech under the Espionage Act.

138244 F. at 536.

${ }^{187}$ See supra note 101 and accompanying text. 
were beside the point in construing the falsity clause. ${ }^{158}$

Hand's discussion of the remainder of the Espionage Act made clear that his objection to judging speech by its tendencies did not depend on the limitation of the first clause to "false statements." While conceding the Postmaster's position that "to arouse discontent and disaffection among the people with the prosecution of the war and with the draft tends to promote a mutinous and insubordinate temper among the troops," Hand refused to find a violation of the insubordination clause. ${ }^{169} \mathrm{He}$ also granted that praise of convicted opponents of the draft has "a tendency to arouse emulation in others." ${ }^{\text {180 }}$ Yet such tendencies, he concluded, did not constitute obstruction. Hand would declare language illegal under these provisions only if it could "be thought directly to counsel or advise insubordination"181 or, under the obstruction clause, to constitute "direct advocacy of resistance to the recruitment and enlistment service."162

Hand acknowledged that "words are to be taken, not literally, but according to their full import." He insisted, however, that "the literal meaning is the starting point for interpretation."163 Hand reasoned that words "which have no purport but to counsel the violation of law" are themselves illegal. "Yet to assimilate agitation, legitimate as such, with direct incitement to violent resistance, is to disregard the tolerance of all methods of political agitation which in normal times is a safeguard of free government." Hand feared that such an interpretation would render illegal all political speech "apt to create a seditious temper," and he concluded that in passing the Espionage Act "Congress had no such revolutionary purpose in view."164 Although Hand readily conceded

168 244 F. at 539.

188 Id.

${ }^{160}$ Id. at 541.

${ }^{161}$ Id. at $540-41$.

${ }^{162} I d$. at 541. At the conclusion of his opinion, Hand added a final objection to evaluating the legality of speech by its tendency. Such a test would make it difficult if not impossible for defendants to disprove the charges against them and would create an imprecision in standards and a discretion in administration inconsistent with "the normal assumption that law shall be embodied in general propositions capable of some measure of definition." "The tradition of English-speaking freedom," Hand reasoned, "has depended in no small part upon the merely procedural requirement that the state point with exactness to just that conduct which violates the law." Id. at 543. Hand was sensitive to the problems of vagueness emphasized before the war by Gilbert Roe and Theodore Schroeder of the Free Speech League. See Rabban, supra note 4, at 534-35, 577-78 \& n.346. Roe may have stressed this point in oral argument before Hand.

183244 F. at 542.

184 Id. at 540 . 
that illegal counseling "may be accomplished as well by indirection as expressly," ${ }^{\prime 165}$ he did not indicate in his decision when it was necessary to look beyond the "literal meaning" of words. In Masses, at least, he saw no reason to do so. ${ }^{166}$

Hand also made clear throughout his opinion that he was construing the Espionage Act rather than interpreting the Constitution. He granted the possibility "that Congress may forbid the mails to any matter which tends to discourage the successful prosecution of the war." "It may be," he added, "that the fundamental personal rights of the individual must stand in abeyance, even including the right of the freedom of the press ...."167 He assumed Congress could repress hostile criticism "in the throes of a struggle for the very existence of the state."168 And he reiterated that he was not questioning "the power of Congress to establish a personal censorship of the press under the war power."168 Hand, however, accompanied each of these caveats with the confident assertion that Congress had not chosen to invoke such power in passing the Espionage Act. Indeed, he concluded that "its exercise is so contrary to the use and wont of our people that only the clearest expression ... justifies the conclusion that it was intended."170 Yet the legislative history of the Espionage Act, which Hand never cited in his opinion, demonstrates the congressional intent to punish the very kind of antiwar material that prompted the Postmaster to declare The Masses "nonmailable."171

Hand's decision in Masses did not take hold. A circuit court judge wrote an opinion disapproving Hand's test while staying the

165 Id.

168 In a decision after the Second Circuit's reversal in Masses, Hand tried to elaborate his original position on indirect counseling. He acknowledged that illegal "counsel or advice need not be explicit, since the meaning of words comprises what their hearers understand them to convey." United States v. Nearing, 252 F. 223, 227 (S.D.N.Y. 1918). He cited Mark Antony's funeral oration as an example of language that "can in fact counsel violence while it even expressly discountenances it." Id. at 228.

In Nearing, Hand defined the test of speech under the insubordination and obstruction clauses as the question: "What words make their utterer responsible for crimes which in the course of nature, including the wills of others, may be expected to follow from them?" Id. at 227. I assume that his construction of these clauses, which was considerably looser than analogous passages in Masses, incorporated Hand's interpretation of the Second Circuit's reversal. See infra note 177 (quoting Hand's understanding of Second Circuit's Masses holding).

107244 F. at 538.

188 Id. at 540 .

160 Id. at 543 .

170 Id. at 540. But see infra text accompanying notes 531-32 (Hand privately admitting his "ignorance" about the history of free speech).

17 See supra section II. 
injunction, ${ }^{172}$ and a full panel of the Second Circuit soon reversed Hand's order. ${ }^{173}$ After quoting Hand's statement that anything less than urging resistance to law is protected, the panel simply expressed its disagreement. The Second Circuit used the familiar approach of evaluating "the natural and reasonable effect of what is said" and held that an incitement to crime may be indirect. ${ }^{174}$

This reversal and the general lack of support for his approach apparently led Hand to reject free speech claims that judges who reached protective decisions in other cases might have accepted. In United States $v$. Nearing, ${ }^{178}$ after pointing out that he had "tried unsuccessfully" in Masses to suggest that the legality of speech must be "determined by the character of the words themselves," Hand announced that he would not attempt another definition. ${ }^{176}$ Instead, he relied on the holding by the Second Circuit in Masses, which he cited throughout his opinion as if to disclaim personal responsibility for following its approach. ${ }^{177}$ And in United States v. Eastman, ${ }^{178}$ while again citing the Second Circuit's reversal in Masses, Hand went out of his way to distinguish a protective decision by another federal district judge. ${ }^{179}$ Having lost his theoretical battle over the appropriate protection for speech under the Espionage Act, Hand was evidently reluctant to fight a rearguard action by limiting the use of his opponents' weapons in ways that might have achieved some practical benefits. ${ }^{180}$

172 Masses Publishing Co. v. Patten, 245 F. 102 (2d Cir. 1917).

173 Masses Publishing Co. v. Patten, 246 F. 24 (2d Cir. 1917).

${ }^{174} I d$. at 38 . In a concurring opinion, Judge Ward emphasized that not every publication may be punished for its "indirect effect" to obstruct recruitment. "In addition to the natural effect of the language on the reader," he maintained, "the intention to discourage is essential." Id. at 39. Judge Ward did not indicate what would constitute evidence of such an intention.

178252 F. 223 (S.D.N.Y. 1918).

178 Id. at 227-28.

173 Id. at 228, 229, 230, 231. Hand paraphrased and explained his understanding of the Second Circuit's holding:

That though in the form of public discussion words, which might not themselves amount to advice or counsel to violate the law, would nevertheless make their author criminally responsible if they were in fact the cause of the results forbidden, and if they were uttered with the specific intent of producing those results. In short, the test was made, not objective only, but in part subjective, as is indeed often the case in the definition of crime.

Id. at 228.

178252 F. 232 (S.D.N.Y. 1918).

${ }^{170} \mathrm{Id}$. at 233 (distinguishing United States v. Schutte, 252 F. 212 (D.N.D. 1918), discussed infra text accompanying notes 194-200, 206).

${ }^{180}$ In Nearing and Eastman, Hand did not require the government to make any showing that the relationship between language and its probable effects was "proximate" or "direct." Nor did Hand require proof in indictments that the offensive speech actually reached 
Other judges, while following the traditional tests of intent and "bad tendency," nevertheless were able to place some restraints on the government's use of title I, section 3 as a dragnet to secure convictions for antiwar speech. Judge Bourquin's directed verdict in United States $v$. Hall ${ }^{181}$ was the earliest of these decisions. The defendant, in the presence of men registered for the draft, used harsher language than most convicted speakers. In addition to typical comments about President Wilson being a "Wall Street tool," he stated that "he would flee to avoid going to the war." Yet Judge Bourquin pointed out that these statements were made, in "badinage," at picnics, and during saloon arguments in a small village in Montana, sixty miles from the nearest railroad, and apparently hundreds of miles from the nearest army base. ${ }^{182} \mathrm{He}$ cited the standard interpretation of intent, but maintained that the natural consequences and surrounding circumstances in this case made the inference of intent to interfere with the operation and success of the military "absurd."18s Bourquin added that many of the substantive offenses defined by the Espionage Act "are of the nature of attempts," which require "proximity to the object of their operation."184 By defining military forces to include only men actually in service, rather than all registered men, Bourquin found insufficient "proximity to constitute attempts." And the final clause, by creating the crime of obstruction rather than "mere attempts to obstruct," could not be violated without a showing of actual "injury to the service."185 Like Hand in Masses, Bourquin

men subject to the draft or actually enlisted. Eastman, 252 F. at 233; Nearing, 252 F. at 230. But see infra text accompanying notes 185, 194, 202 (other federal judges imposed these requirements). And Hand upheld use of the insubordination clause against subsequent issues of The Masses even though he acknowledged that the Second Circuit expressed doubt about its applicability. Eastman, 252 F. at 233. Hand's public acceptance of defeat, however, did not prevent his private adherence to his original position in subsequent correspondence with Holmes and Chafee. See Gunther, supra note 14, at 731-50.

Judges in other contexts, faced with tensions between their beliefs and formal legal principles, have reached unnecessarily harsh judgments by retreating to a mechanical formalism in areas where they retained discretion, a technique that helped them deny personal responsibility for their decisions. See R. Cover, Justice Accused (1975) (analyzing decisions by antislavery judges before the Civil War); see especially id. at 199, 233. Perhaps Hand's recognition that he had to conform to the Second Circuit's reversal of his decision in Masses similarly prompted him to reach excessively restrictive results in subsequent Espionage Act cases.

381248 F. 150 (D. Mont. 1918).

182 Id. at 152 .

18s Id. at 152-53.

184 Id. at 152.

${ }^{185}$ Id. at 153. Bourquin invoked the doctrine of impossibility to support his analysis. He reasoned that just as a man who intended to kill could not be convicted of attempted 
also observed that the false statements punished by the Espionage Act did not include "opinions, beliefs, intentions, and arguments." pression" that the Espionage Act could punish "mere disloyal utterances" and slander or libel of public officials. While conceding that such expressions could violate state law when tending to breach the peace, he emphasized that since the Sedition Act of 1798 Congress, perhaps reflecting "the genius of democracy," had not made them federal crimes. ${ }^{187}$

Judge Bourquin's opinion in Hall so disturbed the Department of Justice that its lawyers sought an amendment of the Espionage Act. ${ }^{188}$ Similar decisions during this period might have deterred some later prosecutions and encouraged other judges to withhold weak cases from juries. Eventually, a small minority of district judges followed Judge Bourquin's example, perhaps because they had been disappointed by earlier jury verdicts of guilty. Judge Amidon, who tried many Espionage Act cases before directing acquittals in two, wrote Chafee that many ordinarily competent jurors believed that they had to return a guilty verdict in order to prove their loyalty. ${ }^{189}$

A few circuit court reversals of guilty verdicts also construed the Espionage Act in ways that limited its restrictions on speech. These protective decisions, often echoing Judge Bourquin's reasoning in Hall, addressed many of the same issues of statutory construction as their restrictive counterparts while reaching opposite results. Several courts carefully distinguished unpopular but legal opinions from the "false statements" prohibited by the Espionage

murder if he shot a pistol at someone several miles away, so the defendant, whatever his intent, could not be convicted for comments made hundreds of miles from the nearest military forces. $I d$.

188 Id. at 152.

187 Id. at 153-54.

${ }^{188}$ In an address to the Executive Committee of the American Bar Association while Congress was considering such an amendment, Attorney General Gregory cited this "celebrated case" as an example of "the ineffectiveness of [the Espionage] law when applied by a judge not in accord with its purposes." Gregory observed that most district judges "properly left to the jury the duty of determining the intention of the accused from the language used and the circumstances under which it was used," but he expressed confidence that "a much more drastic" amendment being considered by Congress "will form the basis for convictions in all federal districts." Suggestions of Attorney-General Gregory, 4 A.B.A. J. 305, 306-07 (1918). Gregory got what he wanted in the 1918 "Sedition Act." Act of May 16, 1918, ch. 75, 40 Stat. 553; see 1918 ATT'Y GEN. ANN. REp. 18.

${ }^{189}$ Letter from Judge Charles F. Amidon to Zechariah Chafee, Jr. (August 29, 1919) (Zechariah Chafee, Jr., Papers, Box 4, Folder 1, Harvard Law School Library) [hereinafter cited as Chafee Papers]. 
Act. For example, Judge Munger dismissed charges of falsity against statements alleging that Jesus Christ was the only person better than the Kaiser, ${ }^{100}$ that "Germany can't be whipped,"191 and that the Red Cross "are a lot of thieves and grafters." ${ }^{102}$ He came to the same conclusion about the claim that Wilson and the munitions makers were responsible for the war. According to Munger, no consensus existed about the causes of the war; indeed, historians could probably cite a hundred. "[T] ing a false statement because he undertakes to single out one thing as the cause of the war," he reasoned, "is placing a construction upon the law that was not contemplated."193

Other protective decisions stressed that there must be some "proximity" between language and the crimes defined by the Espionage Act; intent could not be inferred from the "secondary," "remote," or "indirect" effects of language. ${ }^{104}$ However unfair, unjust, unpatriotic, or disloyal, speech could not be punished without some substantial evidence of its impact. ${ }^{198}$ The protective decisions conceded that the effect of speech can be inferred from its surrounding circumstances, but they emphasized that these circumstances must be examined carefully. ${ }^{196}$ As a result, several judges maintained that the failure to specify them in the pleadings or indictment precluded a conviction. ${ }^{187}$ Where "circumstances are an element of a crime," Judge Amidon observed, "[they] cannot be left to speculation or inference, but must be clearly and directly charged." Simply to identify the challenged language and assert illegal intent "would be a mere legal conclusion."

190 United States v. Frerichs 2 (D. Neb. 1918) (Interp. of War Stat. Bulletin 85).

191 Id.

"2 United States v. Koenig 2 (E.D. Mo. 1918) (Interp. of War Stat. Bulletin 166).

198 Id; see also Kammann v. United States, 259 F. 192, 193 (7th Cir. 1919); Sandberg v. United States, 257 F. 643, 646, 648 (9th Cir. 1919).

19 See, e.g., United States v. Mills 2 (D.N.D. 1919) (Interp. of War Stat. Bulletin 204); United States v. Henning 15 (E.D. Wis. 1919) (Interp. of War Stat. Bulletin 184); United States v. Koenig 3-4 (E.D. Mo. 1918) (Interp. of War Stat. Bulletin 166); United States v. Schutte, 252 F. 212, 215 (D.N.D 1918).

198 See, e.g., United States v. Mills 4 (D.N.D. 1919) (Interp. of War Stat. Bulletin 204); United States v. Schutte, 252 F. 212, 213, 215 (D.N.D. 1918).

198 See infra notes $200-05$ and accompanying text.

197 See infra notes 198-99.

138 United States v Schutte, 252 F. 212, 214 (D.N.D. 1918); see also Grubl v. United States, 264 F. 44, 46 (8th Cir. 1920); Fontana v. United States, 262 F. 283, 286-87 (8th Cir. 1919); Shilter v. United States, 257 F. 724, 725-26 (9th Cir. 1919); United States v. Koenig 1, 3 (E.D. Mo. 1918) (Interp. of War Stat. Bulletin 166); cf. Balbas v. United States, 257 F. 17, 23, 25 (1st Cir. 1919) (indictment sufficient but no circumstances permitting inference of unlawful intent). 
cuit court held a pleading lacking such specificity a violation of the sixth amendment because it failed to inform the defendants of the charges against them. ${ }^{199}$

Moreover, the kind of surrounding circumstances that prompted most judges and juries to find violations of the Espionage Act did not satisfy some of the few judges who reached protective decisions. Focusing on the nature of the audience, judges held that speech to a women's club, ${ }^{200}$ or in private conversations, ${ }^{201}$ could not be punished under the Espionage Act. Some courts explicitly held that speech must reach men in the military before provisions of the Espionage Act could apply. ${ }^{202}$ Another judge added that the identification of a soldier in the audience was not itself sufficient to constitute an attempt to cause insubordination. ${ }^{203}$ In a different context, a circuit court criticized a trial judge for failing to require the jury to decide if the defendant was "so drunk that he was incapable of entertaining the specific criminal intent required by the Espionage Act." ${ }^{204}$ And, in the case of a member of the Nonpartisan League charged with obstruction for his statement that the sons of farmers, not of merchants and bankers, were fighting in France, Judge Amidon identified a variety of extenuating circumstances. Amidon pointed out that the speaker and his organization had been harassed with accusations of disloyalty, and that the speech was extemporaneous, constantly interrupted, and delivered at the end of a heated political campaign. ${ }^{205}$

Several of the protective decisions emphasized that Congress did not intend the Espionage Act to punish unpatriotic or disloyal language. "Such a perversion of law," one judge concluded, "would

109 Foster v. United States, 253 F. 481, 482 (9th Cir. 1918); see supra note 162 (Hand's emphasis in Masses on specificity).

${ }^{200}$ United States v. Schutte, 252 F. 212, 214 (D.N.D. 1918).

${ }^{201}$ See, e.g., Fontana v. United States, 262 F. 283, 288 (8th Cir. 1919); Harshfield v. United States, 260 F. 659, 660 (8th Cir. 1919); Wolf v. United States, 259 F. 388, 393 (8th Cir. 1919); Sandberg v. United States, 257 F. 643, 648 (9th Cir. 1919).

${ }^{202}$ See, e.g., Grubl v. United States, 264 F. 44, 46-48 (8th Cir. 1920); Kammann v. United States, 259 F. 192, 194 (7th Cir. 1919); Shilter v. United States, 257 F. 724, 725-26 (9th Cir. 1919).

${ }^{203}$ United States v. Henning 16 (E.D. Wis. 1919) (Interp. of War Stat. Bulletin 184).

204 Stenzel v. United States, 261 F. 161, 163 (8th Cir. 1919).

205 United States v. Mills 3-4 (D.N.D. 1919) (Interp. of War Stat. Bulletin 204). Judge Veeder, in a prosecution under the penal code for conspiracy to obtain an illegal draft exception, gave an instruction that might have convinced some juries in Espionage Act cases to acquit. According to Veeder, "circumstances which on their face may appear criminal are often, when explained by their connection with surrounding circumstances, undeniably innocent." United States v. Jacobson 1 (E.D.N.Y. 1918) (Interp. of War Stat. Bulletin 39). 
itself be a supreme act of disloyalty . . ..206 Another judge observed that if Congress had wanted to pass a sedition law, it could have modeled one after the Sedition Act of 1798 . He construed the provisions of the Espionage Act as evidence that Congress "industriously sought to keep away" from this ancient precedent. ${ }^{207} \mathrm{~A}$ number of decisions cited the express prohibition of "unpatriotic or disloyal" language in the 1918 amendment to the Espionage Act $^{208}$ as proof that the original law had no such purpose. ${ }^{208}$

A few remarkable circuit court reversals, decided after the Armistice and after most Espionage Act decisions, recognized the difficulty of reaching fair verdicts during war, the very problem identified by Gilbert Roe during the hearings on the Espionage bill and expressed privately by Judge Amidon to Chafee. ${ }^{210}$ The courts pointed out that patriotic citizens had become "particularly impatient"211 and "to a certain extent [had] lost their mental poise."212 Only two months after a unanimous Supreme Court, in opinions written by Justices Brandeis and Holmes, upheld convictions in its first four Espionage Act cases, ${ }^{213}$ one circuit court observed:

It is natural, in time of war, when patriotic sentiment is high, that it is particularly difficult to secure a fair trial for men accused of crimes connected with the war. At such times the task of the court becomes especially difficult and requires great care to prevent miscarriage of justice. These are practical considerations, which must be constantly borne in mind, or the verdicts of juries in such cases will mistakenly become expressions of their hatred for unpatriotic acts in general, instead of their careful judgment on the facts shown by the evidence in the particular case. Patriotism must not become,

${ }^{208}$ United States v. Schutte, 252 F. 212, 213 (D.N.D. 1918).

${ }^{207}$ United States v. Henning 17 (E.D. Wis. 1919) (Interp. of War Stat. Bulletin 184).

${ }^{208} \mathrm{I}$ do not discuss this amendment except in passing references because most of the federal prosecutions were brought before it was enacted. See Z. CHAfre, supra note 2, at 46. Decisions under its provisions, moreover, generally followed the approach of the earlier Espionage Act cases. For background on the 1918 amendment, see id. at 44-46; H. PETBRson \& G. FrTe, supra note 92 , at 208-21.

${ }^{209}$ See, e.g., Wolf v. United States, 259 F. 388, 391 (8th Cir. 1919); Von Bank v. United States, 253 F. 641, 643 (8th Cir. 1918); United States v. Henning 17 (E.D. Wis. 1919) (Interp. of War Stat. Bulletin 184); United States v Schutte, 252 F. 212, 215 (D.N.D. 1918).

110 See supra note 101 and text accompanying note 189.

211 Stokes v. United States, 264 F. 18, 25 (8th Cir. 1920).

212 Hall v. United States, 256 F. 748, 752 (4th Cir. 1919).

${ }_{213}$ Debs v. United States, 249 U.S. 211 (1919); Frohwerk v. United States, 249 U.S. 204 (1919); Sugarman v. United States, 249 U.S. 182 (1919); Schenck v. United States, 249 U.S. 47 (1919). 
even innocently, a cloak for injustice. The right of an accused in the courts of this nation to a fair trial must not vary with the character of the crime. ${ }^{214}$

This judicial perception came too late and too infrequently to make any difference in most cases.

\section{The Initial Wartime Cases in the Supreme Court}

Supreme Court review of prosecutions against antiwar speeches and publications began with its Selective Draft Law decisions in January 1918. ${ }^{215}$ The Court issued its first four Espionage Act opinions in March $1919 . .^{216}$ In all of these cases, the Supreme Court unanimously affirmed convictions while giving little or no attention to the first amendment. Subsequent scholars, preoccupied with Justice Holmes and the "clear and present danger" test, ${ }^{217}$ have generally not noticed the connections between the Selective Draft Law and the Espionage Act cases, connections emphasized by the government lawyers who briefed the first Espionage Act appeals and acknowledged by Holmes in Schenck $v$. United States. ${ }^{218}$

\section{A. The Selective Draft Law Cases}

Ten appeals of convictions under the 1917 Selective Draft Law reached the Supreme Court a year before the first group of Espionage Act cases. All concentrated on attacking the constitutionality of the draft. The Supreme Court, prompted by the Solicitor General, ${ }^{219}$ consolidated six of them and, in the Selective Draft Law Cases, ${ }^{220}$ upheld the draft as a legitimate exercise by Congress of its constitutional power "to declare war" and "to raise and support armies."221

214 Wolf v. United States, 259 F. 388, 394 (8th Cir. 1919).

215 Ruthenberg v. United States, 245 U.S. 480 (1918); Kramer v. United States, 245 U.S. 478 (1918); Goldman v. United States, 245 U.S. 474 (1918).

${ }_{216}$ Debs v. United States, 249 U.S. 211 (1919); Frohwerk v. United States, 249 U.S. 204 (1919); Sugarman v. United States, 249 U.S. 182 (1919); Schenck v. United States, 249 U.S. 47 (1919).

${ }^{217}$ See Rabban, supra note 4, at 516-22, 579-81, 595, and the sources cited therein.

${ }^{218}$ See infra note 278 and text accompanying note 323 (discussing briefs and Holmes's opinion in Schenck). Two articles do refer to Goldman and to Holmes's citation of it in Schenck: Filvaroff, Conspiracy and the First Amendment, 121 U. PA. L. REv. 189, 202-03 (1972); Ragan, supra note 14, at 34.

${ }^{219}$ Motion by the United States to Advance, Ruthenberg v. United States, 245 U.S. 480 (1918).

320245 U.S. 366 (1918).

221 Id. at 377 (quoting U.S. Const. art. I, § 8). 
The Court issued additional opinions in the four remaining cases to deal with "other questions"222 left unresolved by its consolidated opinion. In three of these four cases-Ruthenberg $v$. United States, Kramer v. United States, and Goldman v. United States-the government claimed that an antiwar speaker had violated the criminal code by inducing or conspiring to induce an eligible person not to register. ${ }^{223}$

Like many cases implicating freedom of speech in the generation before World War I, neither the briefs nor the decisions in Ruthenberg, Kramer, and Goldman explicitly addressed the meaning of the first amendment or concentrated on free speech issues. The attorneys for the convicted speakers, however, did challenge the punishment for speech. Protesting that the indictment failed to show how the defendants' "multifarious political activities" aided a man not to register, ${ }^{224}$ the lawyers in Ruthenberg claimed that the indictment was unconstitutionally vague. ${ }^{225}$ The government responded by asserting that the defendants "knew the speeches that caused their arrests," ${ }^{228}$ and the Supreme Court dismissed this claim by the defendants' attorneys as "so unsubstantial as not to require even statement."222

Harry Weinberger, the lawyer for the defendants in Goldman and Kramer, maintained in his brief for Emma Goldman and Alexander Berkman ${ }^{228}$ that nothing either defendant ever said or wrote could be construed as an overt act in a conspiracy to urge men not

212 Goldman v. United States, 245 U.S. 474, 476 (1918).

223 Ruthenberg v. United States, 245 U.S. 480, 481 (1918) (inducement); Kramer v. United States, 245 U.S. 478, 479 (1918) (conspiracy); Goldman v. United States, 245 U.S. 474, 475 (1918) (conspiracy). The fourth case, Jones v. Perkins, 245 U.S. 390 (1918), affirmed the denial of a petition for a writ of habeas corpus from a man arrested for failing to register as required by the Selective Draft Law.

224 Brief for Plaintiffs in Error at 23, Ruthenberg v. United States, 245 U.S. 480 (1918) [hereinafter cited as Ruthenberg Brief]. The attorneys pointed out that their clients had never met the man they allegedly aided. Was this man, the attorneys asked, "influenced by printed leaflets, form, letter, speech, song, public exhortation, private appeal? And when? Where?" According to the attorneys, all their clients "could know till the moment of trial was, they were charged with 'aiding' a man unknown to them, somewhere in Cleveland, sometime before the registration, not to register. It was a legal ambush into which they were driven blindfold[ed]." Id.

225 Id. at 25.

236 Brief for the United States at 104-05, Ruthenberg v. United States, 245 U.S. 480 (1918).

2275 U.S. at 483.

${ }^{228}$ Goldman and Berkman were indicted as co-conspirators; the indictment is reprinted in Brief on Behalf of the Plaintiffs-in-Error at 1-5, Goldman v. United States, 245 U.S. 474 (1918) [hereinafter cited as Goldman Brief]. 
to register. ${ }^{229}$ The government, Weinberger pointed out, had produced "no evidence that they advised people to disobey the law." Nor had it submitted any proof that anything Goldman or Berkman said or wrote had even reached men subject to the draft. Weinberger acknowledged that Goldman and Berkman strongly disapproved of the draft, but he stressed that "no one was ever convicted before of the crime of disapproving of laws." berger's view, a jury under the influence of the prevailing "war hysteria"231 had convicted his clients simply for expressing their views on a "public question." "232 Conceding that Goldman and Berkman distinguished between opposition to conscription and advice not to register, the government's brief supported the jury verdict because "the result reasonably deduced from advice not to be conscripted is to refuse to take the first step."233

The Supreme Court emphasized that its opinion sustaining the draft in the Selective Draft Law Cases disposed of all the constitutional questions in Goldman. ${ }^{234}$ The Court rejected Weinberger's arguments about the sufficiency of the evidence by attributing them to the erroneous "assumption that the power to review embraces the right to invade the province of the jury by determining questions of credibility and weight of evidence." Despite this disclaimer, the Court did review the record and "without recapitulating the evidence"-indeed, without referring to any of it-concluded in a summary sentence that "the proposition that there was no evidence whatever of guilt to go to the jury is absolutely devoid of merit."23s The Court reached the same determination in Kramer. As long as there was "evidence tending to show guilt," the case could not be taken from the jury. Once again, the Court, without identifying such evidence, claimed to have found it. ${ }^{236}$

229 Id. at $19-20$.

${ }^{230}$ Id. at 20. The logic of the government's position, Weinberger added, would have imposed liability on the corporations that successfully brought legal challenges against the first income tax laws and on the railroads who resisted the eight-hour day. Id.

231 Id. at 18.

${ }^{232} I d$. at 20 . The brief pointed out that Goldman had "expressly stated that she cannot and would not tell people not to register." Id. at 21.

23s Brief for the United States at 120, Goldman v. United States, 245 U.S. 474 (1918). In fact, Goldman and Berkman indicated that they would not have registered had the law applied to them. Id. at 117-19 (quoting speeches by Berkman and Goldman).

234245 U.S. at 476.

235 Id. at 477.

${ }^{236}$ Kramer v. United States, 245 U.S. 478, 479 (1918). 


\section{B. The First Espionage Act Cases}

Schenck, Sugarman, Frohwerk, and Debs reached the Supreme Court the following term. In all four cases, the government charged that antiwar articles and speeches caused or attempted to cause insubordination in the armed forces or obstruction of recruitment or enlistment. ${ }^{237}$ In Schenck and Frohwerk, the government also alleged that antiwar articles provided evidence of a conspiracy, expressly forbidden by section 4 of the Act, ${ }^{238}$ to violate other of its provisions. ${ }^{239}$

Probably because Eugene V. Debs, ${ }^{240}$ the Socialist Party's perennial candidate for president, was the most prominent defendant in an Espionage Act prosecution, his case was the most thoroughly briefed. Seymour Stedman, who defended many socialists in Espionage Act cases and who represented Sugarman and Debs, devoted his main effort to the Debs case, as did Alfred Bettman and John Lord O'Brian, who wrote the government's briefs in all four of the Espionage Act cases. ${ }^{21}$ And Gilbert Roe selected Debs as the Espionage Act case in which to file an amicus brief. ${ }^{242}$

237 The defendants in Schenck, Frohwerk, and Debs were charged under both the insubordination and obstruction provisions. Transcript of Record at 5, Schenck v. United States, 249 U.S. 47 (1919); Transcript of Record at 4, Frohwerk v. United States, 249 U.S. 204 (1919); Transcript of Record at 29, 42, Debs v. United States, 249 U.S. 211 (1919). Sugarman was charged only under the insubordination provision. Transcript of Record at 12, Sugarman v. United States, 249 U.S. 182 (1919). The first count of Debs's indictment charged him under the provision forbidding publication of "false reports," Transcript of Record at 2, Debs v. United States, 249 U.S. 211 (1919), but the United States Attorney withdrew this count before trial, id. at 151.

2se Act of June 15, 1917, ch. 30, tit. I, \& 4, 40 Stat. 217, 219.

239 See Schenck, 249 U.S. at 48-49; Frohwerk, 249 U.S. at 205.

240 See R. Ginger, The Bending Cross: A Biography of Eugene Victor Drbs 353-84 (1949) (discussing Espionage Act prosecution of Debs and Court's decision).

${ }^{241}$ In his Sugarman brief, Stedman referred the Court to his brief in Debs for a discussion of the first amendment issues applicable to both cases. Brief of Plaintiff in Error at 21, Sugarman v. United States, 249 U.S. 182 (1919) [hereinafter cited as Sugarman Brief]. In their brief in Frohwerk, O'Brian and Bettman only summarized their response to first amendment arguments because the "whole subject had been so thoroughly discussed" in their brief in Debs. Brief for the United States at 18, Frohwerk v. United States, 249 U.S. 204 (1919) [hereinafter cited as Brief for the United States in Frohwerk]. Stedman's brief for Debs was 87 pages, see Brief for Plaintiff in Error, Debs v. United States, 249 U.S. 211 (1919) [hereinafter cited as Stedman Brief for Debs]; the government's reply was 91 pages. See Brief for the United States, Debs v. United States, 249 U.S. 211 (1919) [hereinafter cited as Brief for the United States in Debs].

${ }^{243}$ In his preliminary statement in Debs, Roe explained that he represented Nagler, a plaintiff-in-error in a case "involving the construction and constitutionality" of the same provisions of the Espionage Act. Because the Nagler case would not be reached for argument until after the Supreme Court decided Debs, Roe decided, with the consent of the Solicitor General and Stedman, to file a brief as amicus curiae. Brief of Gilbert E. Roe, as Amicus Curiae, at 1-2, Debs v. United States, 249 U.S. 211 (1919) [hereinafter cited as Roe 
1. The Defendants' Briefs. In his briefs for Debs and Sugarman, Stedman repeated the objections that the defendants in Goldman, Kramer, and Ruthenberg had raised to their indictments. ${ }^{243}$ In his Debs brief, however, Stedman went on to make a quantum leap beyond his predecessors by translating these objections into constitutional arguments. ${ }^{244}$ Stedman called the first amendment "the vital issue of this case." 245 Because the indictment itself presented "no theory of the pleader as to the pertinence of defendant's words to move others to action,"246 any relationship between Debs's speech and the prohibition of the Espionage Act was "left for conjecture of judge and jury."247 According to Stedman, these deficiencies "led to a sedition conviction under a thin disguise of a charge of actual military obstruction by means of words."248 And the first amendment, Stedman concluded, does not permit convictions simply because a jury concludes that a defendant has a "seditious temper."249

Stedman borrowed the phase "seditious temper" from Hand's opinion in Masses, which he quoted at length, identifying it incorrectly, though understandably, as the only case "leading to anything in the nature of a rule as to when the Espionage Act, applied to speech and press, might pass the bounds of constitutional validity."250 $\mathrm{He}$ asserted without citation that Hand's requirement of

Amicus Brief in Debs]. The government eventually confessed error in Nagler. Nagler v. United States, 254 U.S. 661 (1920).

${ }^{243}$ See Sugarman Brief, supra note 241, at 8-16; Stedman Brief for Debs, supra note 241 , at 38 .

${ }^{264}$ In the first paragraph of the section entitled "The indictment fails to charge a crime," Stedman made clear the extent to which his brief in Debs relied on first amendment claims: "The primary argument under this heading is carried over to the general discussion of the right of free speech under a subsequent heading of the brief. At this point we desire merely to call attention to the fictitious character of the pleading as pleading." Stedman Brief for Debs, supra note 241, at 35. Stedman made no reference to the first amendment at the analogous point in his brief for Sugarman. Sugarman Brief, supra note 241, at 8.

${ }^{245}$ Stedman Brief for Debs, supra note 241, at 61. To emphasize the importance of the first amendment in Debs, and perhaps as a warning to the Court that it should resist its frequent inclination to avoid first amendment claims, Stedman introduced his constitutional argument by observing: "The millions in many countries who respond to the idealism of Eugene V. Debs . . . will bluntly speak of the Debs case as a free speech fight." Id. at 61-62.

248 Id. at 64.

247 Id. at 77.

${ }^{248}$ Id. at 64.

248 Id.

${ }^{280}$ Id. at 63; see id. at 65-69 (quoting Hand's opinion in Masses). Other Espionage Act decisions, Stedman maintained, could not be reconciled with the first amendment, which the lower court judges had "easily swept . . . aside." Id. at 63. Roe's amicus brief and the brief for Schenck also cited Hand's opinion in Masses approvingly, though without Stedman's misleading hyperbole. Roe Amicus Brief in Debs, supra note 242, at 10; Brief of 
"purposeful incitement to specific unlawfulness" was simply a restatement of the liability of an accessory at common law, and claimed that it provided the only constitutionally permissible basis for "Congress to make public utterances criminal."251

Stedman criticized as inconsistent with the first amendment any reliance on the "indirect effect" or "the reasonable and natural consequences" of speech to find specific criminal intent under the Espionage Act. ${ }^{262}$ Affirmance of Debs's conviction by the Supreme Court would distort the literal meaning of the statute and suppress the discussion and advocacy of socialist opposition to war. "Antiwar politics would be confined to times of peace, when the issue has not the vitality of national immediacy."25s As a result, discussion of war-the most crucial subject of public policy-would become the exclusive concern of high government officials, and restrictions on free speech would arise in direct proportion to the importance of the issues at stake. Stedman urged the Court not to allow such a "caricature" of the first amendment through a "preposterous perversion of the established precedents of our own history."254

Gilbert Roe's amicus brief in Debs reinforced Stedman's arguments by demonstrating in a particularly effective manner the first amendment implications of the technical and evidentiary objections others had raised. Perhaps because of his broad experience as a member of the Free Speech League and as a frequent litigator of first amendment cases, Roe was able to illustrate vividly the broad implications of the "bad tendency" test. "The most that any jury or any judge can say about any language of a speech or article in the absence of any evidence that it produced a particular effect," Roe argued, "is that it would have a tendency to produce the results complained of ...."2ss Reiterating the basic theme of his testimony while Congress was considering the Espionage bill, Roe added:

Once this court says that public discussion of the measures of government can be punished because of any intent which a jury may find caused the discussion, or because of any

Plaintiffs in Error at 7, Schenck v. United States, 249 U.S. 47 (1919) [hereinafter cited as Brief for Schenck].

282 Stedman Brief for Debs, supra note 241, at 71.

282 Id. at 84.

${ }^{253} \mathrm{Id}$. at 80 .

256 Id. at 84.

${ }^{285}$ Roe Amicus Brief in Debs, supra note 242, at 16. 
result which a jury may think will follow such discussion, then the free speech and free press of the Constitution is destroyed. ${ }^{258}$

According to Roe, limiting public discussion because of its alleged bad tendency, "whether accomplished directly by Congress through an act which frankly declares its purpose, or indirectly by permitting a jury, without evidence, to draw the conclusion that general public discussion of measures of Government cause [sic] injury to the United States by obstructing enlistments, is unconstitutional . . .."257 Roe observed that most district court instructions in Espionage Act cases allowed punishment for the "bad tendency" of speech ${ }^{288}$ and urged the Supreme Court not to adopt a similar construction.

By raising first amendment challenges to the "bad tendency" test, Stedman and Roe attacked the heart of the traditional judicial approach to free speech issues. The briefs for the defendants in these cases, however, did not limit their discussions of the first amendment to this central point. Several made the historical argument that the first amendment superseded the law of seditious libel ${ }^{258}$ and expanded the protection for free speech beyond Blackstone's mere prohibition against prior restraints. ${ }^{260}$ The brief for

${ }^{286}$ Id. at 48; see supra note 101 and accompanying text (discussing Roe's testimony).

237 Roe Amicus Brief in Debs, supra note 242, at 16-17.

${ }^{25 s}$ Id. at 10. Roe maintained that the Espionage Act decisions by the lower federal courts suppressed "substantially all hostile criticism of every measure even remotely connected with the war." Id.

${ }^{280}$ Stedman Brief for Debs, supra note 241, at 74-76, 85; Roe Amicus Brief in Debs, supra note 242, at 32-42; Statement, Brief and Argument for Plaintiff in Error by Frans E. Lindquist at 28-31, Frohwerk v. United States, 249 U.S. 204 (1919) [hereinafter cited as Lindquist Brief for Frohwerk].

280 Stedman Brief for Debs, supra note 241, at 86; Roe Amicus Brief in Debs, supra note 242, at 23-26; Brief for Schenck, supra note 250, at 5-6. Roe devoted particular attention to a refutation of Blackstone. After stating that he had never read a brief or decision interpreting the first amendment in its historical context, Roe Amicus Brief in Debs, supra note 242, at 22, Roe pointed out that Blackstone's discussion of free speech was written a generation before the adoption of the first amendment and simply reflected the effect on English law of the repeal of the Licensing Act in 1694. Id. at 23. He added that Blackstone's conservative views on speech were opposed by many of his English contemporaries. Id. at 25-26. According to Roe:

Mr. Justice Blackstone's belief in the fortunate condition of the English press after the repeal of the licensing acts in 1694 , like his belief in witchcraft, have a historical interest, but there is no more reason for accepting his beliefs about one than about the other as a measure of liberty and freedom in this country today.

Id. at 24. Roe also observed that Professor St. George Tucker, in his 1803 American edition of Blackstone's Commentaries, stated that freedom of the press encompasses subsequent penalties as well as prior restraints. Id. at 44 . 
Schenck stressed that free speech, including the "scrutiny and condemnation" of government officials, promotes the exercise of responsible citizenship and the "spread of truth in matters of general concern" that "is essential to the stability of a republic."261 Stedman claimed that the "degree of tolerance of minority sentiments" is the traditional test of political freedom. ${ }^{262}$ And one brief for Frohwerk suggested that the first amendment prohibits the punishment of any criticisms of government policy that do not meet the Constitution's definition of treason. ${ }^{263}$

In their briefs for Debs, Stedman and Roe rejected the proposition that Congress can rely on the war power to restrict speech, an issue Learned Hand explicitly left undecided in his statutory construction of the Espionage Act in Masses. ${ }^{264}$ If the war power could limit the scope of the first amendment, Stedman argued, public officials would be too eager to discover grave dangers to the state in any "agitation desired to be suppressed." $285 \mathrm{He}$ vigorously maintained that the first amendment's protection of public discussion could not be "swept aside ... as an incident of the war power." ${ }^{286}$ Roe claimed that the first amendment is an absolute prohibition against all exercises of congressional power affecting speech. Just as Congress cannot abridge free speech to borrow money or collect taxes, it cannot abridge free speech to wage war. ${ }^{28 z}$ The first amendment is the constitutional provision "most calculated to preserve our free institutions to ourselves and to posterity." ${ }^{288}$ Unless the "breach already made in the wall of constitutional liberty" by the lower courts' interpretation of the Espionage Act is "speedily and permanently repaired," Roe argued, "it will certainly be enlarged as one exigency after another seems to make it necessary, until the whole structure will give way before the as-

261 Brief for Schenck, supra note 250, at 6 .

${ }^{202}$ Stedman Brief for Debs, supra note 241, at 62; see Brief for Schenck, supra note 250 , at 8 (importance of allowing "honest criticism of the majority by the minority").

${ }^{26 s}$ Lindquist Brief for Frohwerk, supra note 259, at 28-29. In addition, Stedman rejected the "possible" theory that the Espionage Act could punish "instigation to treason." "Congress has no power," Stedman claimed, "to amend or enlarge the definition of treason written into the Constitution." Stedman Brief for Debs, supra note 241, at 85. For a discussion of the relationship between the treason clause and the first amendment, see supra note 110. power).

264 See supra text accompanying notes 167-70 (discussing Hand's construction of war

20s Stedman Brief for Debs, supra note 241, at 74.

260 Id. at 71.

${ }^{267}$ Roe Amicus Brief in Debs, supra note 242, at 19-20, 48.

268 Id. at 20. 
saults of real enemies of constitutional and democratic government."268

2. The Government's Response. The government's reply briefs, submitted by O'Brian and Bettman in the initial group of Espionage Act cases, made explicit much of the reasoning that, though not clearly articulated, seemed to provide the basis for the Supreme Court decisions in Goldman, Kramer, and Ruthenberg. These briefs vigorously disagreed with the defendants' objections to the form of the indictments and to the sufficiency of the evidence. "When the tendency of the words used, rather than the particular words themselves, constitute [sic] the gist of the offense," the government argued in Sugarman, "it is sufficient for the indictment to charge this general tendency, without detailing the particular words."270 The precise words which constitute an attempt are "the evidentiary details of the method by which the unlawful purpose was carried out" and to identify them specifically "would be pleading evidence."271 According to O'Brian and Bettman, their adversaries were incorrectly trying to transform a challenge to the sufficiency of evidence, a question trial judges properly left to juries, into a first amendment case. ${ }^{272}$

O'Brian and Bettman chose their brief in Sugarman to make their most detailed arguments against the relevance of first amendment issues to the Espionage Act litigation. This brief emphasized that the first amendment arguments raised on behalf of Sugarman had been decisively foreclosed by the Supreme Court in Goldman, Kramer, and Ruthenberg. ${ }^{273}$ The only issues of constitutional law in both the earlier cases and Sugarman involved the validity of the Selective Draft Law itself, not the acts which provided the basis for the defendants' convictions. ${ }^{274}$ No other legitimate constitutional attack, they argued, could be raised, "for, obviously, if that statute is valid, the constitutionality of prohibiting attempts to cause violations thereof necessarily and inevitably follows,"275 whether under the Penal Code, as in Goldman, Kramer, and Ruthenberg, or under the Espionage Act as in Sugarman.

$260 I d$. at 21.

270 Brief for the United States at 11, Sugarman v. United States, 249 U.S. 182 (1919) [hereinafter cited as Brief for United States in Sugarman].

${ }^{271} I d$. at 10. See Brief for the United States in Debs, supra note 241, at 23 ("it is difficult to conceive what more could be set forth . . . without pleading evidence").

${ }^{272}$ Brief for United States in Debs, supra note 241, at 77-78.

273 Brief for the United States in Sugarman, supra note 270, at 36.

274 Id. at 36-37.

27s Id. at 37 . 
O'Brian and Bettman did not consider whether the first amendment requires that counseling disobedience of the law be distinguished from other categories of attempts. Since the language of the speeches and publications punished in all of these cases consisted of virtually identical claims by socialists that the war was a capitalist conspiracy in which workers should not participate, ${ }^{276}$ it was easy for O'Brian and Bettman to deny that Sugarman, which involved the same relation between speech and crime as Goldman, Kramer, and Ruthenberg, presented any distinct constitutional issue. O'Brian and Bettman deemed the constitutional question in Sugarman so "frivolous" that "it must have been inserted for the sake of giving a colorable claim to the appeal to this court." ${ }^{\text {277 }}$ According to them, Stedman made his untenable first amendment argument because it was the only possible way to distinguish Sugarman from Goldman, Kramer, and Ruthenberg. The evident weakness of this desperate position, they maintained, "demonstrate[s] that this case is not genuinely and seriously one" raising constitutional questions. Their brief recommended that the Supreme Court dismiss Sugarman's appeal for lack of jurisdiction. ${ }^{278}$

In Debs, probably because Stedman and Roe raised first amendment issues so explicitly, O'Brian and Bettman did not, as they had in the government's other Espionage Act briefs, belittle the constitutional dimensions of the case. Although they suggested that no constitutional question was "necessarily involved" in Debs, O'Brian and Bettman did respond to their adversaries' first amendment claims. Even Stedman, they observed, accepted "intentional incitement to violations of law" as beyond the constitutional protection for free speech, and they insisted that this was just the standard under which Debs had been charged and convicted. Debs's position, O'Brian and Bettman argued, would re-

276 See, e.g., id. at 36.

277 Id. at 37.

${ }^{278}$ Id. In their brief in Schenck, O'Brian and Bettman strongly reiterated this position on the first amendment, even though Schenck's lawyers did not use Stedman's arguments to criticize the indictment. Observing that Sugarman and Schenck had been set for hearing on the same day, O'Brian and Bettman referred to their brief in Sugarman and used almost identical language. They argued that the Selective Draft Law decisions had "foreclosed" any reliance on the first amendment in Schenck. "The cases correspond, the only distinction being that they were brought under different statutes and relate to different stages of the duties of men subject to the draft-distinctions which have no relevance to the question of constitutionality." As in Sugarman, they concluded that the constitutional question "is too well settled adversely to the defendants and too unsubstantial to form the basis of the jurisdiction of this court over this case." Brief for the United States at 20-21, Schenck v. United States, 249 U.S. 47 (1919) [hereinafter cited as Brief for the United States in Schenck].

${ }^{279}$ Brief for the United States in Debs, supra note 241, at 69, 78. 
quire a much more protective rule. $\mathrm{He}$

seems to contend that as he did not express this unlawful advice in words so direct, plain, and unmistakable as to leave no room whatever for the slightest thought or intellectual process on the part of the jury, no need of any process of inference whatever, the constitutional immunity applies to his speech. ${ }^{280}$

This contention would put the government in the impossible position of being "powerless to punish any incitement to lawlessness, however intentional and however effective, so long as it is concealed in veiled, indirect, or rhetorical language."281

O'Brian and Bettman pointed out that Hand's decision in Masses, so heavily relied upon by Stedman, had been reversed by the Second Circuit in language which supported the government's position in Debs. ${ }^{282}$ The trial court's charge to the jury in Debs, they added, was a model of fairness consistent with the proper standard established by the Second Circuit in Masses. ${ }^{283}$ Like many of his district court colleagues, ${ }^{284}$ the judge had told the jury that the Espionage Act did not forbid a citizen to "discuss, criticize, or disapprove" of any proposed or existing law or policy. If Debs only gave his version of the truth in order to reshape national policy through peaceful methods and did not also intend to commit any act prohibited by law, the jury must return a verdict of not guilty. To convict Debs, the judge concluded, the jury would have to find that he had a "specific, willful, criminal intent" and that he used language having "a natural and reasonably probable tendency to cause the results which have been forbidden by these provisions of the espionage law." ${ }^{285}$ In emphasizing this jury charge and the Second Circuit decision in Masses, O'Brian and Bettman reiterated the government's position that a conviction for an unlawful attempt under the Espionage Act could properly be based on a jury determination of the "bad tendency" of language.

In their reply to Roe, O'Brian and Bettman stated in con-

280 Id. at 72.

${ }^{281} I d$.

${ }^{282}$ Id. at 73-74 (quoting Masses Publishing Co. v. Patten, 246 F. 24, 37-38 (2d Cir. 1917)). For a discussion of the Second Circuit's decision, see supra note 174 and accompanying text. Stedman tried without success to minimize the impact of the Second Circuit's reversal. See Stedman Brief for Debs, supra note 241, at 68-71. Roe simply conceded that Hand's decision had been overruled. Roe Amicus Brief in Debs, supra note 242, at 10.

${ }^{283}$ Brief for the United States in Debs, supra note 241, at 75.

${ }^{284}$ See supra text accompanying notes 117-46 (discussing district court instructions under the Espionage Act).

${ }^{285}$ Brief for the United States in Debs, supra note 241, at 76-77. 
clusory language that Debs was not punished for his beliefs or opinions, which they acknowledged would have been unconstitutional, but for a willful attempt, through the use of language, to obstruct recruitment. ${ }^{286}$ Yet O'Brian and Bettman did address Roe's basic concerns. "Mr. Roe claims," they correctly paraphrased,

that by reason of the temper of the public during a war, a law directed at obstruction of the war will inevitably be applied so as to suppress all critical discussion of the war, and that the Espionage Act, as applied by the courts and juries, has produced that effect. ${ }^{287}$

O'Brian and Bettman did not dispute Roe's analysis but contended that his position, in its "zeal for free speech," would subvert the jury system and the separation of powers. ${ }^{288}$ They construed his "plea" as an appeal to the Supreme Court "to ignore the constitutional limitations of its functions and correct what he conceives to be a mistaken legislative policy or mistaken, though lawful, verdicts."289

O'Brian and Bettman responded to most of the defendants' additional first amendment arguments, especially in their main brief in Debs. They characterized Stedman's brief as advocating, contrary to history and precedent, a "field of immunity from Federal interference for all exercise of the vocal organs" and "all products of the printing press." 290 They agreed that the first amendment protects "legitimate political agitation"291 and "hostile criticism of the war," for which the defendants in the Espionage Act cases were prosecuted and convicted went well beyond these bounds. Though they conceded, despite Holmes's decision in Patterson v. Colorado ex rel. Attorney General, ${ }^{293}$ that the first amendment might be broader than Blackstone's rule against prior restraint and might restrict legislative power over speech to traditional common law crimes, ${ }^{294}$ they insisted, contrary to the conclusions of the legal and

${ }^{280}$ Brief for the United States, in Reply to Brief of Gilbert E. Roe, as Amicus Curiae, at

2, Debs v. United States, 249 U.S. 211 (1919) [hereinafter cited as Reply to Roe].

287 Id. at 3.

288 Id.

289 Id. at 3-4.

290 Brief for the United States in Debs, supra note 241, at 69.

29 Brief for the United States in Schenck, supra note 278, at 13.

292 Reply to Roe, supra note 286 , at 2.

203205 U.S. 454 (1907).

294 Brief for the United States in Debs, supra note 241, at 81. 
historical scholars cited in the defendants' briefs, that seditious speech could be punished at common law. ${ }^{285}$ In response to Roe's lengthy attack on the Sedition Act of 1798, they maintained that the authorities cited by Roe were "partisan documents put forth in the heat of a bitter political contest,"296 and they pointed out that John Marshall had written a substantial defense of the Sedition Act's constitutionality. ${ }^{207}$

Notwithstanding their assertion of Congress's right to punish seditious libel, O'Brian and Bettman took pains to distinguish the 1917 Espionage Act from the "objectionable features" of the 1798 Sedition Act, which "sought to punish libelous attacks on the Government." The Espionage Act, they asserted, "carefully avoids that pitfall" by limiting its prohibitions to "interference with the process of raising armies," a valid exercise of the war power vested in Congress by the Constitution. ${ }^{298}$ This vital power, upon which the survival of the nation depends, "includes the power to punish willful obstruction of that process, whether that obstruction be by spoken or written word or by other means."298 O'Brian and Bettman also invoked the war power to refute the argument that the constitutional clause on treason defines the limits of prohibited speech. This argument, they maintained, would render the war power meaningless because obstruction of war laws arises more from commercial than from treasonable motives. ${ }^{300}$ The Constitution defined treason, but it "has left to Congress the definition of other offenses which may interfere with the conduct of a war."301

O'Brian and Bettman ended the government's main brief in Debs by relying on recent Supreme Court decisions. If the war

298 Id.

298 Reply to Roe, supra note 286, at 9 (citing Marshall, The Address of the Minority in the Virginia Legislature to the People of the State, which contains a vindication of the Constitutionality of the Alien and Sedition Laws (Library of Congress, Class E 327, Book A22)).

${ }^{287}$ Id. at 11. O'Brian and Bettman quoted at length from Marshall's pamphlet. Id. at 12-16. The pamphlets on both sides, they asserted, "were early guns in that contest between Federal and State rights and between strict and broad construction of the Constitution, in which Marshall's views prevailed ...." Id. at 11.

${ }^{283}$ Brief for the United States in Debs, supra note 241, at 83; accord Reply to Roe, supra note 286 , at 9 .

299 Brief for the United States in Debs, supra note 241, at 80; accord Brief for the United States in Frohwerk, supra note 241, at 22-23; Reply to Roe, supra note 286, at 8.

${ }^{300}$ Brief for the United States in Frohwerk, supra note 241, at 21-22. The government observed that laws enacted by Congress under the authority of the war power included the raising of war revenue, food regulations, and the control of exports, as well as the Espionage Act. Id. Once again, the government did not view restrictions on speech as presenting special problems.

${ }^{301}$ Id. at 22. 
power allows Congress to deprive a man of liberty or even life in order to raise an army, as the Supreme Court held in the Selective Draft Cases, ${ }^{302}$ they reasoned that it must also allow Congress to punish obstruction of recruitment. ${ }^{303}$ They maintained that the "right of self-preservation" identified by the Supreme Court in United States ex rel. Turner v. Williams $s^{304}$ further supported the validity of the Espionage Act. ${ }^{305}$ And to support the proposition that obstruction by speech or press is not entitled to special protection, they cited the Supreme Court's decision only months earlier in Toledo Newspaper Co. v. United States, ${ }^{306}$ which relied on the "bad tendency" theory to sustain, as a willful obstruction of the administration of justice, a newspaper's contempt conviction for criticizing judicial conduct during a trial. O'Brian and Bettman maintained that the war power of Congress can limit free speech as readily as the contempt power of a court. ${ }^{307}$ "No authority," they concluded, "can be adduced for the defendant's contention that there is a constitutional right to obstruct by speech the exercise of the power to raise armies so long as the speaker does not urge a violation of law." 308

3. The Supreme Court's Decisions. The Supreme Court decided Schenck and Sugarman on March 3, 1919, and Frohwerk and Debs on March 10, 1919. All four decisions unanimously sustained convictions for speech in violation of the Espionage Act, and focused more on questions of criminal law than on the first amendment. In his opinion in Sugarman, Brandeis accepted the

soz 245 U.S. 366 (1918).

${ }^{303}$ Brief for the United States in Debs, supra note 241, at 89.

so4 194 U.S. 279, 294 (1904). For a discussion of lower court reliance on Turner in Espionage Act cases, see supra note 147 and accompanying text.

${ }^{305}$ Brief for the United States in Debs, supra note 241, at 89-90.

306247 U.S. 402,419 (1918) ("The test . . . is the character of the act done and its direct tendency to prevent and obstruct . . . ."). Justice Holmes wrote a dissent in Toledo, in which Justice Brandeis concurred. Holmes, silently retreating from his opinion in Patterson v. Colorado ex rel. Attorney General, 205 U.S. 454 (1907), pointed out that the statute governing the courts' contempt power confined it to "misbehavior of any person in their presence, or so near thereto as to obstruct the administration of justice." Toledo, 247 U.S. at 423 (Holmes, J., dissenting). "Without invoking the rule of strict construction," Holmes concluded that " 'so near as to obstruct' means so near as actually to obstruct-and not merely near enough to threaten a possible obstruction." Id. Holmes reasoned that under this statute the summary proceeding of contempt, rather than the regular process of indictment, is justified only if the possibility of obstruction is "imminent" and an emergency demands "immediate action." Id. at 423-25. Holmes's focus here on imminence and immediacy provides a striking contrast to his neglect of these requirements in Schenck, Frohwerk, and Debs, discussed infra notes 317-63 and accompanying text.

${ }^{802}$ Brief for the United States in Debs, supra note 241, at 89-90.

sos Id. at 89. 
government's invitation to dismiss the case for lack of jurisdiction because the defendant did not present any substantial constitutional question. ${ }^{309}$ Brandeis, however, arrived at this conclusion for reasons different from those the government suggested, which further obscured the underlying first amendment issues. Brandeis did not respond to the government's argument, derived from Goldman, Kramer, and Ruthenberg, that the punishment of speech as an attempt to violate a valid statute cannot possibly implicate the first amendment. ${ }^{310}$ Nor did he discuss any of the extensive constitutional claims made in Stedman's brief for Debs, even though Stedman concluded his brief for Sugarman by referring to those arguments "in order to save repetition and the time of this court."311 Rather, Brandeis relied on a factor ignored by the briefs of the parties; he simply made the plausible but debatable observation that Stedman's only two constitutional exceptions involved jury instructions which "clearly embodied" his original requests. ${ }^{\mathbf{1 1 2}}$ In declining jurisdiction and in refusing to discuss first amendment issues, Brandeis observed that "mere reference to a provision of the Federal Constitution, or the mere assertion of a claim under it, does not authorize this court to review a criminal proceeding ....."313

Unlike Brandeis in Sugarman, Holmes refused to accept the government's contention that the first amendment should not, or need not, be addressed in Schenck, Frohwerk, and Debs. His treatment of free speech claims, however, essentially extended the prewar tradition of judicial hostility and neglect. Holmes discussed the first amendment in one paragraph in Schenck, ${ }^{314}$ and then relied on Schenck in dismissing similar claims in Frohwerk ${ }^{\mathbf{3 1 5}}$ and Debs. ${ }^{316} \mathrm{He}$ never mentioned the Masses litigation or other protective precedents and legal authorities cited in the defendants'

${ }^{309}$ Sugarman v. United States, 249 U.S. 182, 185 (1919).

${ }^{310}$ See supra notes $273-78$ and accompanying text.

s11 Sugarman Brief, supra note 241, at 21 .

312 Sugarman, 249 U.S. 182, 185 (1919). Brandeis included in his opinion the texts of Stedman's requested instructions and the trial judge's actual charge. Id. at 184-85.

There were some arguably significant differences between Stedman's requests and the judge's charge. Stedman had objected to the judge's statement that freedom of speech protects honest criticism of a law. Stedman had not included the word "honest" in his requested instructions, and he maintained, in an argument ignored by Brandeis, that the judge's charge abridged free speech by allowing the improper inference that criticism must be honest in order to be lawful. Sugarman Brief, supra note 241, at 20.

s13 Sugarman, 249 U.S. at 184.

314249 U.S. at $51-52$ (1919).

316249 U.S. at 206-07 (1919).

s16 249 U.S. at 215 (1919). 
briefs. Instead, Holmes concentrated on issues of criminal law ${ }^{317}$ and accepted most of the positions advocated by the government. Holmes approved punishment based on the indirect tendency of speech, upheld substantial judicial deference to jury evaluations of evidence, and supported greater restrictions on speech during times of war. In all three cases, his analysis bore a remarkable similarity to his prewar decisions, particularly his opinion in Fox $v$. Washington. ${ }^{318}$

Although Debs was the most thoroughly briefed of the three cases, Holmes chose Schenck as the vehicle for discussing first amendment issues, perhaps because the defendants in Schenck, unlike those in Frohwerk or Debs, had sent antiwar circulars to men accepted for military service, a somewhat more sympathetic factual context for affirmance. Holmes maintained that the defendants would not have mailed such a document "unless it had been intended to have some effect, and we do not see what effect it could be expected to have upon persons subject to the draft except to influence them to obstruct the carrying of it out." ${ }^{319} \mathrm{He}$ also rejected the claim that no conspiracy existed, an argument which, in Holmes's view, "only impairs the seriousness of the real defence," 320 the first amendment. Holmes then wrote a paragraph on the first amendment emphasizing his continued adherence to the "bad tendency" approach. .21 $^{32}$

Although the briefs in Schenck, unlike those in Debs, did not attack this approach as being inconsistent with the first amendment, Holmes assumed that Schenck claimed first amendment

317 Kalven pointed out that Holmes treated Debs as "a routine criminal appeal," Kalven, supra note 14, at 238, an observation Gunther applied to Schenck and Frohwerk as well. Gunther, supra note 14, at 736 n.83. "Read freshly with the eyes of today," Kalven accurately concluded, "the outcome in Debs is shocking." Kalven, supra note 14, at 236. But read in the context of Supreme Court decisions in the generation preceding Debs, and of the lower court decisions in Espionage Act cases, the reasoning and results in all of these cases are depressingly predictable.

318236 U.S. 273 (1915). In Fox, Holmes upheld the conviction of the editor of an article advocating nude bathing. Holmes strained to reject Gilbert Roe's argument that the applicable statute, which punished publications for their "bad tendency," was "an unjustifiable restriction of liberty and too vague for a criminal law." Id. at 277; see Corwin, supra note 14, at 326-29 (comparing Fox and Schenck and concluding they are "indistinguishable"); Rabban, supra note 4, at 534-36 (discussing Fox).

s19 Schenck, 249 U.S. 47, 51 (1919).

${ }^{320}$ Id. at 50 . On the previous page, Holmes had made clear that he considered the first amendment the defendants' "real defence." He stated that the defendants brought their case on first amendment grounds and "have argued some other points also of which we must dispose." Id. at 49.

ss1 Id. at 51-52. 
protection even if the circulars did tend to obstruct the draft. ${ }^{322}$ Holmes spent the remainder of the paragraph emphasizing his disagreement. He observed that Goldman could be considered to dispose of Schenck, but he "thought fit to add a few words" on the first amendment because the defendants raised this constitutional concern and Goldman did not specifically refer to it. ${ }^{323}$ Holmes retreated from his position equating the first amendment with Blackstone's prohibition against prior restraints. ${ }^{324} \mathrm{He}$ also admitted that "in many places and in ordinary times" the publications punished in Schenck would be protected by the first amendment. But he pointed out that "the character of every act depends upon the circumstances in which it is done." 325

Holmes then wrote the two sentences that Chafee soon made famous as the "clear and present danger" standard:

The question in every case is whether the words used are used in such circumstances and are of such a nature as to create a clear and present danger that they will bring about the substantive evils that Congress has a right to prevent. It is a question of proximity and degree..$^{326}$

Though the words "clear and present danger," as Chafee immediately recognized, ${ }^{327}$ had protective overtones, in its context this passage does not appear to announce a libertarian standard of first amendment interpretation. In the sentence immediately following, Holmes apparently concluded that the war power can override the first amendment, addressing the issue left open by Hand in Masses and debated in the briefs in Debs. "When a nation is at war," Holmes reasoned, "many things that might be said in time of peace are such a hindrance to its effort that their utterance will

322 Id. at 51.

${ }^{323}$ Id. at 52.

${ }^{324}$ "It well may be," Holmes acknowledged, "that the prohibition of laws abridging the freedom of speech is not confined to previous restraints, although to prevent them may have been the main purpose, as intimated in Patterson v. Colorado, 205 U.S. 454, 462." 249 U.S. at 51-52.

${ }^{325} 249$ U.S. at 52. Holmes illustrated this point in language which has since become famous: "The most stringent protection of free speech would not protect a man in falsely shouting fire in a theatre and causing a panic." Id. He also cited a prewar free speech case, Gompers v. Bucks Stove \& Range Co., 221 U.S. 418, 439 (1911), which upheld a labor injunction by distinguishing normal speech from an unlawful conspiracy giving language "a force not inhering in the words themselves." See Rabban, supra note 4, at 531-32 (discussing Gompers).

${ }^{326}$ Schenck, 249 U.S. at 52.

${ }^{327}$ See supra notes 551-66 and accompanying text (discussing Chafee's interpretation of "clear and present danger"). 
not be endured so long as men fight and that no Court could regard them as protected by any constitutional right." ${ }^{328}$ The "circumstances" of war, Holmes seemed to be saying, are themselves likely "to create a clear and present danger" that speech will hinder the nation's effort, thereby producing one of "the substantive evils Congress has a right to prevent." In his very next sentence, moreover, Holmes recurred to the "bad tendency" doctrine. Citing Goldman, Holmes concluded: "If the act (speaking, or circulating a paper), its tendency and the intent with which it is done are the same, we perceive no ground for saying that success alone warrants making the act a crime." "s28 Like the lower federal courts in Espionage Act cases, ${ }^{330}$ Holmes in Schenck inferred intent from the probable consequences and surrounding circumstances of speech. This sequence, contrary to the subsequent assertions of Chafee and others, strongly suggests that Holmes did not consider "clear and present danger" a libertarian replacement for the "bad tendency" doctrine he himself had often invoked in prior decisions. It seems inconceivable that Holmes would use the word "tendency," stress the unimportance of a successful act, and rely on cases that did not demonstrate any sensitivity to free speech in order to elaborate a libertarian test designed as a constitutional bar to convictions based on predicting the tendency of speech. ${ }^{331}$

Holmes's decisions in Frohwerk and Debs relied on Schenck and provide further proof that he did not regard any of these opinions as a significant departure from his restrictive prewar analysis of speech. Neither Frohwerk nor Debs contained the phrase "clear and present danger" and both, on weaker facts than Schenck, sustained convictions under the Espionage Act by relying on the "bad tendency" theory.

In discussing the first amendment in Frohwerk, Holmes considered it necessary to add only slightly to what he had already said in Schenck. He cited one prewar case ${ }^{332}$ for the proposition that the first amendment was "not[] intended to give immunity for

32s Schenck, 249 U.S. at 52.

329 Id.

s30 See supra notes $123,183-85,194-205$ and accompanying text (discussing lower court analysis of intent).

s31 "Clear and present danger," Justice Frankfurter subsequently claimed, "itself is an expression of tendency and not of accomplishment, and the literary difference between it and 'reasonable tendency' is not of constitutional dimension." Bridges v. California, 314 U.S. 252, 296 (1941) (Frankfurter, J., dissenting).

ss2 Robertson v. Baldwin, 165 U.S. 275 (1897); see Rabban, supra note 4, at 539-40 (discussing this case). 
every possible use of language." No "competent person," Holmes commented, would consider a law against counseling murder "an unconstitutional interference with free speech."333 After citing Schenck to support his statement "that a person may be convicted of a conspiracy to obstruct recruiting by words of persuasion," he treated the Frohwerk case as a matter of criminal law. ${ }^{335}$ As Holmes observed, Frohwerk's publications consisted of "the usual repetition that we went to war to protect the loans of Wall Street."338 Even though Frohwerk had deplored draft riots, Holmes did not find "much to choose"337 between his article and Schenck's "impassioned language" Frohwerk used words "that might be taken to convey an innuendo of a different sort." ${ }^{339}$ Holmes's reliance on possible innuendo and his metaphor that "a little breath would be enough to kindle a flame"340 demonstrate his continued use of the "bad tendency" theory to punish speech, as does his acknowledgment that Frohwerk, unlike Schenck, had not made any special effort to contact men eligible for the draft. ${ }^{341}$

Consistent with Goldman, which he did not cite, Holmes also gave great deference to the factual determinations by the jury. Holmes suggested that the record in Frohwerk was inadequate and that a more complete one might have provided grounds for reversing "the very severe penalty imposed." But Holmes felt obligated to reach his decision "on the record as it is." Because he did "not know how strong the Government's evidence may have been," he found it impossible to say "that the articles could not furnish a basis for a conviction." ${ }^{342}$ Holmes, as the government had urged in its briefs, also rejected attacks on the lack of specificity in the indictment $^{343}$ even though, as Stedman effectively argued in his brief for Debs, this very vagueness encourages unsatisfactory records. ${ }^{344}$

243 U.S. $204,206$.

${ }_{334} I d$.

${ }^{335}$ Weaknesses in the record, Holmes stated, "have caused us to consider the case with more anxiety than if it presented only the constitutional question which was the theme of the principal argument here." Id.

${ }^{336}$ Id. at 207.

337 Id.

338 Schenck, 249 U.S. at 51.

${ }^{339}$ Frohwerk, 249 U.S. at 207.

310 Id. at 209.

341 Id. at 208.

342 Id. at 209.

${ }^{343}$ Id. at 209-10.

34 See Stedman Brief for Debs, supra note 241, at 38. 
And Holmes dismissed the suggestion that the treason clause limits the punishment for speech by claiming that it "need no more than to be stated" to be refuted. ${ }^{345}$ Holmes did acknowledge in Frohwerk that even during war some speech cannot be penalized: "We do not lose our right to condemn either measures or men," he reasoned, "because the Country is at war." ${ }^{346}$ But he negated the potential value of his one libertarian concession by refusing to limit jury determinations of the possible consequences of speech.

Even more clearly than Frohwerk, Debs demonstrated Holmes's continued reliance on the tendency of speech as the test for its legality and his willingness, bordering on eagerness, to sustain jury findings of fact. Despite the excellence and thoroughness of the analysis in the briefs, which contained by far the most extensive discussions of the first amendment among all the briefs filed in the Supreme Court during the preceding generation, ${ }^{347}$ Holmes, in a peremptory sentence, stated that any first amendment issues in Debs were "disposed of" in Schenck. ${ }^{348} \mathrm{He}$ also asserted, with no explanation beyond the citation of Frohwerk, that the indictment was sufficient. ${ }^{349}$ As O'Brian and Bettman had urged in their brief for the government, ${ }^{360}$ Holmes treated Debs as if it presented evidentiary rather than constitutional questions, but at least Holmes, in contrast to Chief Justice White in Goldman, Kramer, and Ruthenberg, ${ }^{351}$ explained in Debs the basis for his conclusion that the evidence supported the guilty verdict.

Holmes acknowledged that the "main theme of ... [Debs's] speech was socialism, its growth, and a prophecy of its ultimate success," topics which could not be punished under the Espionage Act. ${ }^{352}$ However, Holmes added, "if a part or the manifest intent of the more general utterances was to encourage those present to obstruct the recruiting service and if in such passages such encouragement was directly given, the immunity of the general theme may not be enough to protect the speech." ${ }^{\text {ss3 }}$ Later in his opinion,

${ }^{345}$ Frohwerk, 249 U.S. at 210; see supra note 110 (discussing this claim).

346 Frohwerk, 249 U.S. at 208.

${ }^{347}$ See supra notes $240-42$ and accompanying text.

so Debs, 249 U.S. at 215.

s49 Id.

350 See supra notes $270-72$ and accompanying text.

3s1 See supra notes 234-36 and accompanying text.

${ }^{362}$ Debs, 249 U.S. at 212.

ss3 Id. at 212-13. Holmes later repeated that if the "natural and intended effect" of Debs's speech "would be to obstruct recruiting," it "would not be protected by reason of its being part of a general program and expressions of a general and conscientious belief." Id. at 215 . 
Holmes suggested that the encouragement contained in a part of the speech need not be direct. Much of Debs's speech, he pointed out, "had only the indirect though not necessarily ineffective bearing on the offences alleged." ${ }^{354}$ The fact that Debs told his audience that prudence required him not to disclose the full force of his opposition to the war was, for Holmes, an intimation that they "might infer that he meant more" rather than an indication, to be counted in Debs's favor, that he had tried to avoid the prohibitions of the Espionage Act. ${ }^{355}$ Based on these observations, Holmes concluded that the speech contained sufficient evidence "to warrant the jury in finding that one purpose of the speech, whether incidental or not does not matter, was to oppose not only war in general but this war, and that the opposition was so expressed that its natural and intended effect would be to obstruct recruiting." 368

Consistent with the approach of all judges except Learned Hand in Masses, Holmes stated that evaluating the tendency of language as evidence of the speaker's intent is a principle "too well established and too manifestly good sense to need citation of the books." ${ }^{357}$ Holmes stressed his approval of punishing speech for its "bad tendency" by following the government's lead in praising the trial judge's charge to the jury. ${ }^{368}$ Holmes apparently approved the common practice whereby judges, after giving juries essentially neutral instructions, allowed them to consider virtually any speech that the government considered objectionable. ${ }^{369} \mathrm{He}$ also rejected Stedman's objection to the admissibility at trial of the "Anti-war Proclamation and Program" of the Socialist Party, which, according to Holmes, "contained the usual suggestion that capitalism was

sst Id. at 214.

sss Id. at 213. The laughter and applause from the audience that followed these statements by Debs provides support for Holmes's conclusion. See R. GINGER, supra note 240, at 356. In his biographer's opinion, Debs intended his speech not simply "to arouse resentment and opposition to the war," but also "to taunt the Federal authorities into placing him on trial." Id. at 353. I am grateful to Benno Schmidt for highlighting these passages during a faculty seminar he gave at the University of Texas School of Law on Jan. 20, 1983.

${ }^{358}$ Debs, 249 U.S. at 214-15.

357 Id. at 216. Holmes had read Hand's opinion in Masses before writing his opinions in Schenck, Frohwerk, and Debs. Less than a month before the Supreme Court announced these decisions, Holmes complimented Hand on the "admirable form" of Masses while adding that "I haven't the details in my mind and will assume for present purposes that I should come to a different result." Letter from Oliver Wendell Holmes, Jr., to Learned Hand (Feb. 25, 1919) (Learned Hand Papers, Box 103, Folder 24, Harvard Law School Library) [hereinafter cited as Hand Papers], reprinted in Gunther, supra note 14, at 758.

${ }^{358}$ Debs, 249 U.S. at 214-15; see supra note 283 and accompanying text (praise of trial judge in government brief).

${ }^{368}$ See supra notes $123-37$ and accompanying text (discussing jury instructions). 
the cause of the war." ${ }^{380}$ Holmes reasoned that Debs's acceptance of this program would be evidence of his intent to obstruct the recruitment service. In Debs, as in Frohwerk, Holmes deferred to jury findings on the indirect tendency of speech. ${ }^{361}$

Holmes continued the prewar judicial tradition of hostility to first amendment values by using the "bad tendency" theory to reject free speech claims in Schenck, Frohwerk, and Debs. Even within this framework, he did not take as his model the few decisions by district and circuit judges, some of which had been brought to his attention in the defendants' briefs, ${ }^{362}$ that protected some antiwar speech by requiring specificity in indictments and a direct relationship between speech and potential effects. ${ }^{363}$ Instead, Holmes adopted the looser construction of the Espionage Act that had prevailed in the lower federal courts.

\section{The Doctrinal Origins of "Clear and Present Danger"364}

In 1922, Chafee wrote Holmes to ask for "[a]ny light that you can give me on the background of your opinion in the Schenck case." In particular, Chafee wondered if "your test of clear and present danger . . . was at all suggested to you by any writers on the subject or was the result entirely of your reflections." 365 Holmes's brief response confirms the analysis suggested by the texts of Schenck, Frohwerk, and Debs, and provides fascinating insights into the phrase that had already assumed crucial importance in first amendment interpretation. Apologizing for having to "make a hurried answer" based on "ancient memory," Holmes replied:

The expression that you refer to was not helped by any book that I know of. I think it came without doubt after the later cases (and probably you-I do not remember exactly) had taught me that in the earlier Paterson [sic] case, if that was the name of it, I had taken Blackstone and Parker of Mass. as unrefuted, wrongly. I simply was ignorant. But I did think

360249 U.S. at $215-16$.

se1 Id.

362 See Roe Amicus Brief in Debs, supra note 242, at 8-10; Stedman Brief for Debs, supra note 241, at 37; Brief for Schenck, supra note 250, at 7-14.

sos See supra notes 194-205 and accompanying text.

sos Valuable discussions with William Powers helped clarify the contents and organization of this section.

${ }^{365}$ Letter from Zechariah Chafee, Jr., to Oliver Wendell Holmes, Jr. (June 9, 1922) (Chafee Papers, supra note 189, Box 14, Folder 12). Chafee hoped that this test would "drive out the old notion of bad tendency," a comment to which Holmes did not reply. 
hard on this matter of attempts in my Common Law and a Mass. case-later in the Swift case (U.S.) -and I thought it out unhelped..$^{366}$

"Parker of Mass." is Isaac Parker, the former Chief Justice of the Massachusetts Supreme Judicial Court, whose 1825 decision in Commonwealth $v$. Blanding ${ }^{387}$ approved Blackstone's rule against prior restraints. Holmes's reference to the "later cases" is unclear; the Supreme Court did not modify its approval of Blackstone in Patterson v. Colorado ${ }^{368}$ until Holmes's own opinion in Schenck. Perhaps Holmes was thinking of Toledo Newspaper Co. $v$. United States, ${ }^{368}$ in which he, joined by Justice Brandeis just months before Schenck, dissented in a case similar to Patterson. In any event, Holmes's letter to Chafee, in language understandably more explicit than that of a judicial decision, underlined the retreat from Patterson which he signaled in the text of his Schenck opinion.

Holmes's acknowledgment of his reliance on his earlier thinking about the law of criminal attempts, particularly on his Common Law, ${ }^{\mathbf{3 7 0}}$ is even more revealing because it provides convincing

${ }^{386}$ Letter from Oliver Wendell Holmes, Jr., to Zechariah Chafee, Jr. (June 12, 1922) (Chafee Papers, supra note 189, Box 14, Folder 12). This letter was handwritten and is difficult to decipher. Ragan, supra note 14, at 26 \& n.12, reads "Patriotic" where I read "Paterson," and claims that Holmes was referring to Schenck. Because Schenck is the case in which Holmes first used the words "clear and present danger," it is unlikely that he would refer to Schenck as an "earlier" case when discussing the origins of this phrase. See Bogen, supra note 14 , at $100 \& \mathrm{n} .20$ (independently coming to the same conclusion about Holmes's handwriting). Ragan's claim that the "later cases" refer to Frohwerk and Debs, id. at $26 \mathrm{n} .12$, is also improbable. Holmes retreated from Blackstone's view, which he had accepted in Patterson, in the text of Schenck itself, and Schenck preceded Frohwerk and Debs. See supra note 324 and text accompanying note 293. These corrections do not alter my view that Ragan's article contains an excellent analysis of the important relationship between Holmes and Chafee.

387 20 Mass. (3 Pick.) 304, 313 (1825).

38s Patterson v. Colorado ex rel. Attorney General, 205 U.S. 454, 462 (1907) (quoting Blanding, 20 Mass. (3 Pick.) at 313).

${ }^{368} 247$ U.S. 402, 422 (1918) (Holmes, J., dissenting); see supra note 306 and accompanying text (discussing Toledo).

${ }_{370}$ O.W. Holmes, supra note 16. M. Howe, Justice Oliver Wendell Holmes, The Proving Years, 1870-1882 (1963), the second volume of Howe's biography of Holmes, places The Common Law "at the center of the stage." Id. at 253. See id. at 160-200 for Howe's discussion of some of the themes that I will emphasize in the text that follows. Rogat, The Judge as Spectator, 31 U. CHI. L. Rev. 213 (1964), is an exceptionally profound article that examines the complex relationships between Holmes's life and work, and places them in historical context. G. GiLmore, The Ages of American Law 48-56 (1977), contains a trenchant summary of The Common Law. Gilmore's analysis exhibits the same fearless cynicism as Holmes's thought.

Edmund Wilson's book on Civil War literature includes a revealing chapter on Holmes. 
additional support for the conclusion, suggested by the language of his first Espionage Act opinions, that he did not use the words "clear and present danger" as a libertarian alternative to the "bad tendency" test. Holmes's discussion of attempts, in this book and in his subsequent opinions, is part of a cohesive framework of analysis that informed his approach to all legal questions. A review of the key doctrines of The Common Law helps relate his Espionage Act decisions to the totality of his work.

\section{A. The Common Law}

Holmes completed The Common Law, "the most important book on law ever written by an American," "371 in 1881, the week before his fortieth birthday. This milestone was particularly important to Holmes, who believed that "if a man was to do anything he must do it before $40 .{ }^{\text {"372 }}$ Holmes tried to reduce the common law to fundamental principles of broad applicability. For the remaining fifty years of his long life, he relied on these principles, and often on the precise language of The Common Law, even in constitutional adjudication. . $^{373}$ "Both as an aphorist and as a judge," Yosal Rogat has pointed out, "Holmes rarely changed his mind." 374 As Brandeis had observed of Holmes: "He has said many things in their ultimate terms, and as new instances arise they just fit in."37s

1. Fundamental Themes. Two fundamental themes pervade The Common Law. Holmes maintained that legal development necessarily replaces internal and moral standards with external and objective ones and that the law must enforce the community's will against individual claims. Near the beginning of his book,

E. WILSON, Patriotic GoRe 743-96 (1962). Wilson observes that Holmes, perhaps uniquely among judges, never dissociated his professional work from broader issues. Id. at 781 .

371 Rogat, supra note 370 , at 214.

372 Letter from Oliver Wendell Holmes, Jr., to Mrs. Charles S. Hamlin (Oct. 12, 1930), quoted in M. Hows, supra note 370, at 135 . The Common Law, according to Howe, was the "achievement by which he wanted to be judged at the age of forty." M. HowE, supra note 370 , at 135 . Holmes wrote The Common Law while in private practice and spent virtually all his non-practicing time over a six-year period on this project. Id. at 253 . Edmund Wilson also emphasizes Holmes's concentrated ambition. E. Wrison, supra note 370, at 754-56.

s73 Rogat, supra note 370, at 214, 247. According to Howe, Holmes, even in teaching constitutional law, was most interested in the "philosophical structure and historic roots of the common law." M. Howe, supra note 370, at 31. Soon after he completed The Common Law, Holmes was appointed to the Supreme Judicial Court of Massachusetts and never wrote another scholarly book. Thus The Common Law was his only comprehensive theoretical work. G. Gilmore, supra note 370 , at 51.

374 Rogat, supra note 370 , at 214.

${ }^{373}$ Quoted in id. at 247. 
Holmes promised that he would demonstrate that the law, though rooted in primitive desires for revenge against blameworthy conduct and often retaining the language of morals, "is continually transmuting those moral standards into external or objective ones, from which the actual guilt of the party concerned is wholly eliminated." "376 A few pages later, he announced his other major theme: "The first requirement of a sound body of law is, that it should correspond with the actual feelings and demands of the community, whether right or wrong." ${ }^{377}$ Holmes assumed that communities, like individuals, are ultimately motivated by "justifiable selfpreference." "If a man is on a plank in the deep sea which will only float one," he elaborated, "and a stranger lays hold of it, he will thrust him off if he can. When the state finds itself in a similar position, it does the same thing." 378

With obvious disdain, Holmes quickly dismissed the Kantian argument that the harshness of the second theme denies men their inherent natural rights to equality and reduces them to things. ${ }^{379}$ "If man lives in society," Holmes observed sardonically, "he is liable to find himself so treated." 380 Kant's moralistic "dogma of equality" might be a laudable ideal, but, Holmes maintained, rules of law should be based on tougher, more realistic views about human nature. ${ }^{381}$ Holmes's views were distinctly those of a Social Darwinist. ${ }^{382}$ The law appropriately expresses the community's

376 O.W. Holmes, supra note 16, at 38. Holmes was much more interested in demonstrating the contemporary pervasiveness of external standards throughout the law than in tracing their historical roots. See M. HowE, supra note 370, at 168-69. Gilmore persuasively argues that the lectures constituting The Common Law only

pretend to be a historical survey of the development of a few fundamental common law principles which, according to Holmes, had recurrently manifested themselves in the several fields he chose to deal with-principally criminal law, torts, and contracts. In fact, the historical underpinning was patently absurd, even when it had not been deliberately distorted. I do not mean to suggest that Holmes was a poor historian or that he did not know what he was doing. He was an excellent historian and knew more about what he was doing than most of us do. He was making a highly original, essentially philosophical statement about the nature of law. For reasons which he never explained, he chose to dress his statement in the misleading disguise of pseudo-history. Perhaps the disguise was a way of sugarcoating the pill-of making the new and unfamiliar appear to be old and familiar. Perhaps it was an elaborate joke which it amused Holmes, who was of a sardonic turn of mind, to play on his audience.

G. GiLMORE, supra note 370, at 52 .

s77 O.W. Holmes, supra note 16 , at 41 .

378 Id. at 44.

${ }^{379}$ Id. at $42-44$.

s8o Id. at 44.

ssi Id. at $43-44$.

s82 Legislation, Holmes asserted in an unsigned law review comment, "like every other device of man or beast, must tend in the long run to aid the survival of the fittest." 7 AM. L. 
self-preference, he reiterated, by treating "the individual as a means to an end, and uses him as a tool to increase the general welfare at his own expense." 383

2. The Relationship Between Community Will and Objective Standards. In his typically cryptic manner, ${ }^{384}$ Holmes did not explain the full meaning of his often brilliant prose. He gave the clear impression that his two fundamental themes were related, but never stated precisely how. He did, however, leave enough hints to allow a plausible reconstruction.

Holmes apparently believed that the general welfare is achieved when the community deters actions it deems dangerous or harmful. Thus the law is primarily designed "only to induce external conformity to rule," 385 and prevention of deviance becomes "the chief and only universal purpose of punishment." scheme, a theory of retribution that posits a "mystic bond between wrong and punishment" 387 has no function and may even interfere with the realization of social goals. Holmes attributed the retributive theory of justice to the idealism he discredited as unrealistic. ${ }^{388}$

Holmes also seemed to deny that punishing or rewarding individual motives has any bearing on the desired social results. $\mathrm{He}$ therefore entirely divorced individual blameworthiness from liability. He acknowledged that the modern legal system includes the concept of culpability, which he considered a psychological necessity whose "denial would shock the moral sense of any civilized

REv. 583, 583-84 (1873), quoted in M. HowE, supra note 370, at 45. He rejected the "tacit assumption of the solidarity of the interests of society," and claimed instead that the "struggle for life" that "is constantly putting the interests of men at variance with those of the lower animals . . . is equally the law of human existence." Id., quoted in part in M. Howe, supra note 370, at 43-44. "Holmes's demand, in effect, was that we recognize that the Darwinian view of nature compels an adjustment in traditional theories of law and of sovereignty." M. Howe, supra note 370 , at 44 . Rogat calls Holmes a "crude" Social Darwinist. Rogat, supra note 370 , at 231 .

sss O.W. HolmEs, supra note 16, at 46-47.

sst Felix Frankfurter observed this quality in Holmes's judicial opinions. Federal Maritime Bd. v. Isbrandtsen Co., 356 U.S. 481, 523 (1958) (Frankfurter, J., dissenting). See generally, G. GILMORE, supra note 370, at 52, 56; Rogat, supra note 370, at 238-39. It is reassuring that even Edmund Wilson found The Common Law "opaque." E. Wnson, supra note 370 , at 780 .

sss O.W. Holmes, supra note 16, at 49.

${ }^{386}$ Id. at 46.

${ }^{387}$ Id. at 42.

sss See id. at 42-47. See generally Rogat, supra note 370, at 225 (criticizing Holmes's failure to acknowledge the importance of "general commitments to fairness, generality and neutrality" as constituting a "fundamentally impoverished account of legal phenomena"). 
community." ${ }^{\text {s89 }}$ But culpability is retained only by imposing liability for conduct that the community considers blameworthy in an idealized average man. Holmes reasoned that "a law which punished conduct which would not be blameworthy in the average member of the community would be too severe for that community to bear." 390 However, the conduct of this average man "of ordinary intelligence and reasonable prudence," often represented by the jury, "is an external or objective standard when applied to any given individual." Someone "morally without stain" may nevertheless be punished if he lacks the qualities of the average man. ${ }^{391}$

The origins of Holmes's attachment to externality may have been more psychological than logical. ${ }^{392}$ Certainly, the connection he posited between community will and "external conformity to rule" 393 does not entail his conclusion that attention to individual motives is unrelated to achieving this conformity. An individual's internal state may affect his likelihood of obeying a given rule,,$^{394}$ as Holmes himself recognized in extreme cases such as infancy and madness. ${ }^{395}$

Whatever the source of Holmes's views, he spent much of The Common Law "reducing" various forms of modern legal liability to external standards. He observed that "acts, taken apart from their

${ }^{388}$ O.W. Holmes, supra note 16 , at 50 ; see id. at $49-51$.

${ }^{300} \mathrm{Id}$. at 50.

s91 Id. at 51 .

${ }^{392}$ Howe considers Holmes's "desire for certainty in law" the principal explanation for his emphasis on externality. M. Howe, supra note 370 , at 197. Rogat argues convincingly that Howe's view is incomplete. According to Rogat, Holmes, rather than appreciating certainty more than his contemporaries, "minded less ... [its] unjust consequences." Rogat, supra note 370, at 221-22. Much of the brilliance of Rogat's article lies in its demonstration that Holmes's obsession with external standards of liability, as well as many of his other professional and personal characteristics, originated in his fundamental detachment from life, a trait he shared with other New England Brahmins estranged from, and made marginal by, the Gilded Age. Id. at 228-43.

s93 O.W. HoLmES, supra note 16, at 49.

394 "Even if the general justification of punishment is the utilitarian aim of preventing harm," H.L.A. Hart observed in a review of Howe's 1963 edition of The Common Law,

it is still perfectly intelligible that we should defer to principles of justice or fairness to individuals and not punish those who lack the capacity or fair opportunity to obey. It is simply not true that such a concern with the individual only makes sense within a system of retribution .... .

Hart, Book Review, N.Y. Rev. of Books, Oct. 17, 1963, at 15-16; see infra note 401 (actor's personality key element of modern theories of criminal attempt).

395 O.W. Holmes, supra note 16, at 50. Aside from such exceptions, Holmes reiterated, external standards "take no account of incapacities." Id. "If they fall on any one class harder than on another," he observed with the acquiescence of the Social Darwinist, "it is on the weakest." Id. at 51. 
surrounding circumstances, are indifferent to the law,"396 and concluded that most "acts are rendered criminal because they are done under circumstances in which they will probably cause some harm which the law seeks to prevent." the foresight of probable harm on which liability depends must be determined by reference to the "prudent man, that is, by general experience,"398 and not by investigating the consciousness of a particular defendant.

B. The Application of Fundamental Themes to Substantive Law

Holmes devoted much of The Common Law to applying his fundamental themes to different substantive areas of the law. His belief in the priority of community will is apparent throughout the book, but he emphasized the centrality of external and objective standards. His analyses of criminal attempts and torts most directly foreshadow his opinions almost forty years later in Schenck, Frohwerk, and Debs.

1. Criminal Attempts. Holmes's discussion of the law of criminal attempts, the specific portion of The Common Law he mentioned in his letter to Chafee, ${ }^{389}$ is particularly interesting and important because the speeches at issue in Schenck, Frohwerk, and Debs were punished as attempts to violate the Espionage Act. Holmes defined an attempt as an overt act that "has failed to bring about the result which would have given it the character of the principal crime." 400 The act is punished as an attempt "if, supposing it to have produced its natural and probable effect, it would have have amounted to a substantive crime." The failure of an act to produce its natural consequences, while properly mitigating the severity of punishment, should not remove liability entirely if the preventive purpose of law is maintained. Thus, in the law of attempts, as in the criminal law generally, "[a]cts should be judged by their tendency under the known circumstances, not by the actual intent which accompanies them." ${ }^{101}$ The common "statement

ase Id. at 54.

297 Id. at 75.

${ }^{308}$ Id. at 56; see id. at 53-57. A legislature, Holmes added, can create liability for acts that it considers dangerous but are not generally recognized as such. Id. at 58-59.

309 See supra note 366 and accompanying text.

100 O.W. Holmes, supra note 16 , at 65 .

${ }^{401}$ Id. at 66. As Francis Allen has pointed out, "modern students of the criminal law have, in general, rejected Holmes' broad espousal of the so-called objective theory of culpability." Allen, Mr. Justice Holmes: Some Modern Views-Criminal Law, 31 U. CHr. L. REv. 257, 257 (1964). The Model Penal Code, for example, includes "culpability" in its definition 
that a man is presumed to intend the natural consequences of his acts," a frequent assertion of federal judges in Espionage Act decisions, was, for Holmes, "a mere fiction disguising the true theory," ${ }^{402}$ another vestige of moral terminology in a mature legal system actually based on external and objective standards.

Holmes recognized that actual intent is an element of many crimes. Yet he cleverly assimilated even these crimes into his general theory. For Holmes, the main purpose for punishing an act is "to prevent some harm which is foreseen as likely to follow that act under the circumstances in which it is done." Typically, prediction is based on "the common working of natural causes as shown by experience." ${ }^{403}$ But sometimes an otherwise innocent act is rendered dangerous because the accompanying actual intent "raises a probability that it will be followed by such other acts and events as will all together result in harm." Salvaging his preference for objective over moral standards, Holmes emphasized that actual intent is important "not to show that the act was wicked, but to show that it was likely to be followed by hurtful consequences" that the law properly seeks to prevent. ${ }^{404}$

Holmes pointed out that bad intent does not necessarily entail liability for a criminal attempt and alluded to judges' prior difficulty in deciding when actual intent is relevant. His proposed solution reiterated his emphasis on the primacy of community demands. "Public policy, that is to say, legislative considerations, are at the bottom of the matter . . .."405 The specific considerations identified by Holmes in The Common Law-"the nearness of the danger, the greatness of the harm," the "degree of apprehen-

of attempt and refers to the actors' purposes and beliefs. Model Penal Code $\S 501$ (1) (Proposed Official Draft 1962); see Wechsler, Jones \& Korn, The Treatment of Inchoate Crimes in the Model Penal Code of the American Law Institute: Attempt, Solicitation, and Conspiracy, 61 CoLum. L. REv: 571, 573 (1961). Drafters of the Model Penal Code explicitly rejected Holmes's approach to criminal attempts. "The primary purpose of punishing attempts," Wechsler, Jones, and Korn maintained, "is to neutralize dangerous individuals and not to deter dangerous acts." They did concede, however, that dangerous conduct "is not entirely irrelevant" because it has "some relation to the dangerousness of the actor's personality." Id. at 587.

${ }^{402}$ O.W. Holmes, supra note 16, at 66 n.2; see id. at 134, 136. Thurman Arnold, who regarded the general concept of a criminal attempt as a useless abstraction, believed that all definitions of intent, whether based on presumed intent or probable consequences, "run into one another" and are all meaningless fictions. Arnold, Criminal Attempts-The Rise and Fall of an Abstraction, 40 YALE L.J. 53, 68, 79-80 (1930).

${ }^{403} \mathrm{O} . \mathrm{W}$. HoLmes, supra note 16 , at 67.

${ }^{104}$ Id. at 68; see id. at 76. But see Allen, supra note 401, at 258.

108 O.W. Holmes, supra note 16, at 68. 
sion," "406 and "the degree of probability that the crime will be accomplished"407 -foreshadow his formulation of "clear and present danger" in Schenck.

2. Torts. Throughout The Common Law Holmes emphasized his position that the same general principles apply to both criminal and civil liability. ${ }^{408}$ Holmes faced his greatest challenge in proving that torts based on fraud, malice, and intent-words that denote "actual wickedness"-also depend on objective and external, ,rather than moral and internal, standards. ${ }^{409}$ This discussion has a double significance: it emphasizes Holmes's adherence to his general theory of liability, and, because several of these torts involve the use of language, it anticipates his later analysis of speech in the Espionage Act cases.

Holmes claimed that the tort of deceit, which consists of uttering false statements with the intent that they persuade another person to act to his detriment, can be "reduced" to external standards in the same manner as other torts and crimes. Here again, intent is based on foresight of consequences judged by "common experience," not by the internal state of mind of a particular defendant. ${ }^{410}$ Knowledge of falsity is measured not by the actual

${ }^{108} I d$.

${ }^{407} I d$. at 69 . In a striking example of his deference to the community will, Holmes illustrated his approach by citing an Alabama decision where "a slave who ran after a white woman, but desisted before he caught her, ha[d] been convicted of an attempt to commit rape." Id. at 68 (citing Lewis v. State, 35 Ala. 380 (1860)). "No doubt the fears peculiar to a slave-owning community," Holmes observed without further comment about a community he fought against during the Civil War, "had their share in the conviction . . . ." Id. at 69.

Holmes's counterexample underlines this deference. He observed that a man cannot be punished for attempted murder, if, after starting out for the location of the intended murder, an obstacle in the course of travel forces him to return home. Id. at 68. Holmes posited no logical distinction between this hypothetical case and the Alabama rape decision. Indeed, the nearness of the danger and the probability of completion seem identical, and murder is a greater harm than rape. Only the "degree of apprehension" of slaves by their owners could, under Holmes's analysis, account for the different results.

Given these views, it is not surprising that Holmes, almost 40 years later, deferred to judgments by Congress and juries that antiwar speech constituted an attempt to interfere with the American military effort during World War I.

${ }^{108}$ See, e.g., id. at $2,44,77,130-31,161-63$. In discussing the torts of trespass and negligence, Holmes reminded his reader that "law takes no account of the infinite varieties of temperament, intellect, and education which make the internal character of a given act so different in different men." The general welfare, he insisted, requires "a certain average of conduct, a sacrifice of individual peculiarities going beyond a certain point." Id. at 108. In tort law, as in criminal law, liability arises "from failure to comply with fixed and uniform standards of external conduct, which every man is presumed and required to know." Id. at 111.

${ }^{100}$ Id. at $130-31$.

410 Id. at 133; see id. at 132-34. 
knowledge or guilt of the defendant, but by an objective standard determined by reference to the average member of a community. ${ }^{411}$

Similarly, Holmes argued that the law of slander does not require actual malice or actual intent. Rather, liability rests on the "manifest tendency" of words to harm, whether or not the defendant actually intended this effect. ${ }^{412}$ As in his discussion of criminal attempts that involve actual intent, Holmes maintained that tort liability varies with the likelihood and the seriousness of the danger. "The possibility of a great danger has the same effect as the probability of a less one, and the law throws the risk of the venture on the person who introduces the peril into the community."413 Liability, he added, does not depend on foresight of specific harm, but on circumstances from which a prudent man would perceive danger. ${ }^{414}$

\section{Prewar Decisions by Holmes in Attempt Cases}

Holmes's prewar decisions in cases involving attempts connect The Common Law with his first Espionage Act decisions and demonstrate the essential consistency of his analysis through almost four decades. In Swift \& Co. v. United States, ${ }^{415}$ the Supreme Court case he identified in his letter to Chafee, ${ }^{416}$ Holmes twice cited his decision in Commonwealth $v$. Peaslee, ${ }^{417}$ probably the "Mass. case" to which he also referred. And in Peaslee, Holmes relied on the opinion he wrote in Commonwealth $v$. Kennedy. ${ }^{418}$ In all three cases, Holmes drew heavily on his discussion of attempts in The Common Law.

In Kennedy, Holmes repeated his underlying emphasis on externality and foreseeability. "As the aim of the law is not to punish sins, but is to prevent certain external results, the act done must

111 Id. at 137.

412 Id. at 138.

113 Id. at 154-55. For example, Holmes observed that the "peril of conduct" begins earlier for slander than for deceit because "the tendency of slander is more universally harmful." Id. at 140.

414 Id. at 147. To a perceptive modern critic, "Holmes' major preoccupations with underlying theory and with the shift from moral to external standards yield sophisticated and arresting results when applied to negligence." But these preoccupations, when applied to fraud, malice, and intent, seem "doctrinaire, unilluminating and even a little foolish." Kalven, Mr. Justice Holmes: Some Modern Views-Torts, 31 U. CHI. L. Rev. 263, 266 (1964).

$\$ 16196$ U.S. 375 (1905).

416 See supra note 366 and accompanying text.

417177 Mass. 267, 59 N.E. 55 (1901), cited in Swift, 196 U.S. at 396, 406.

418170 Mass. 18, 48 N.E. 770 (1897), cited in Peaslee, 177 Mass. at 272, 59 N.E. at 56. 
come pretty near to accomplishing that result before the law will notice it."10 He pointed out that determinations of proximity depend on surrounding circumstances and alluded to additional bases of liability, including "the gravity of the crime, the uncertainty of the result, and the seriousness of the apprehension." Affirming a conviction for attempted murder by poison, Holmes stated that an "unlawful application of poison is [such] an evil [that] . . . even if not enough to kill, [it] would warrant holding the liability for an attempt to begin at a point more remote from the possibility of accomplishing what is expected than might be the case with lighter crimes." 420

Peaslee was an appeal of a conviction for an unsuccessful attempt to burn a building by soliciting a servant to light combustibles arranged by the defendant. Holmes, relying on Kennedy, again observed that the "degree of proximity" necessary to constitute an attempt "may vary with circumstances." Normally, he added, an overt act does not constitute an attempt as long as "further acts are contemplated as needful" to bring about the crime. But evidence of bad intent may so increase the probability of an actual crime that an otherwise innocent act may be considered an attempt. ${ }^{421}$ Holmes made the same point in Swift, a case brought under the Sherman Act alleging an attempted monopoly. ${ }^{422}$ "Not every act that may be done ... to produce an unlawful result," he added, "is unlawful, or constitutes an attempt. It is a question of proximity and degree." 223 The Sherman Act, Holmes emphasized, simply adopted these principles from the common law. ${ }^{\mathbf{2 4}}$

\section{The Continuity of Holmes's First Espionage Act Decisions}

Holmes's Espionage Act decisions in March 1919, particularly the paragraph in Schenck that contains the words "clear and present danger," vividly reflect the influence of these antecedents, sometimes in almost identical language. In these opinions, as in most of his decisions, Holmes did not rehearse the basic underpinnings of the approach he announced in The Common Law. Holmes appropriately recognized that a book designed to present a com-

410170 Mass. at 20,48 N.E. at 770.

${ }^{420} I d$. at 22,48 N.E. at 771.

21177 Mass. at 272,59 N.E. at 56.

422196 U.S. at 396 (intent relevant when further acts necessary to cause crime).

423 Id. at 402.

424 Id. at 396. 
prehensive view of the common law ${ }^{425}$ required a different structure than a judicial decision. But his decisions as a judge were informed by the fundamental principles of The Common Law. He relied on external standards of intent in the Espionage Act decisions and deferred to legislators and juries as agents of the community, even when he questioned the wisdom of the legislation ${ }^{426}$ or doubted the basis for the verdict. ${ }^{427}$

Understandably, Holmes was much less reluctant to incorporate directly into his decisions those portions of The Common Law that elaborated these principles as part of an examination of substantive areas of law. The borrowing so evident in his prewar attempt opinions is equally apparent in Schenck, Frohwerk, and Debs. In The Common Law, Holmes maintained that "acts, taken apart from their surrounding circumstances, are indifferent to the law"; 428 in Schenck, he claimed that "the character of every act depends upon the circumstances in which it was done." ${ }^{\text {229 }}$ In The Common Law, Holmes concluded that most "acts are rendered criminal because they are done under circumstances in which they will probably cause some harm which the law seeks to prevent"; 430 in Schenck, he based liability on "whether the words used are used in such circumstances and are of such a nature as to create a clear and present danger that they will bring about the substantive evils that Congress has a right to prevent."431 In The Common Law, Holmes asserted that intent should be evaluated by the tendency of acts, including utterances, to harm; ${ }^{432}$ in Schenck, Frohwerk, and Debs, he judged the intent requirement of the Espionage Act by the tendency of words rather than through an effort to uncover the defendants' actual states of mind. In Schenck, he observed that "the document would not have been sent unless it had been intended to have some effect,"433 and in Debs, more pointedly, he emphasized that the use of words "tending to obstruct the recruiting service" was evidence that Debs "meant that they should have

\footnotetext{
${ }^{425}$ See O.W. Holmes, supra note 16, at 1.

${ }^{128}$ See, e.g., Fox v. Washington, 236 U.S. 273, 278 (1915); see also supra note 318 and accompanying text.

${ }^{137}$ See, e.g., Frohwerk v. United States, 249 U.S. 204, 208-09 (1919); see also supra notes $342-44$ and accompanying text.

428 O.W. HolmES, supra note 16 , at 54 .

2429 U.S. at 52.

4so O.W. Holmes, supra note 16 , at 75 .

432 U.S. at 52.

432 See, e.g., O.W. Holmes, supra note 16, at 66, 138.

43249 U.S. at 51.
} 
that effect."434 Holmes thought this point too obvious "to need citation of the books,"435 but The Common Law could have provided excellent authority. For Holmes, the phrase "clear and present danger," like the word "tendency," was another way of evaluating the proximity between an act and the forbidden crime that might justify punishing an attempt.

Without explicitly so stating, Holmes apparently considered the speeches and articles punished in the Espionage Act cases as attempts requiring additional acts to cause the substantive evil. The lawyers for Debs had especially emphasized that the connection between the indicted speech and an actual obstruction of the war effort was far from direct. ${ }^{436}$ But Holmes had a familiar method of dealing with this problem: he applied the variables he had identified in The Common Law and had employed in the prewar attempt cases. Immediately following the sentence in Schenck containing the words "clear and present danger," Holmes added the phrase he had used in discussing the relation between intent and attempt in Swift: "It is a question of proximity and degree." In the Espionage Act cases, as in Kennedy, Holmes was particularly concerned about the seriousness and the degree of apprehension by the community of the potential danger. Obstruction of the war effort, like the "great harm likely to result from poison,"4s8 justified the imposition of liability for an attempt at a point more remote than usual from the actual crime. As Holmes observed in Schenck, though the defendants "in many places and in ordinary times" might have been "within their constitutional rights," "many things that might be said in time of peace" lose this constitutional protection "[w] $]$ hen a nation is at war."

Holmes's decisions in Schenck, Frohwerk, and Debs demonstrate his continued deference to majority will and to the external standards of liability that he believed necessary to enforce it. As in his earlier attempt cases, he applied throughout these decisions the concepts, and often the precise terminology, he had already derived from these fundamental principles in The Common Law. He did not seem to regard the wartime speeches and writings against the draft and the war as significantly different from the solicitation

4s4 249 U.S. at 216.

4ss Id.

136 See supra text accompanying notes 243-58 (discussing Stedman and Roe briefs in Debs); see also O.W. Holmes, supra note 16, at 56.

${ }^{437}$ Compare Schenck, 249 U.S. at 52 with Swift, 196 U.S. at 402.

4s8 Commonwealth v. Kennedy, 170 Mass. 18, 22, 48 N.E. 770, 771 (1897).

4s9 249 U.S. at 52. 
to light a fire in Peaslee. ${ }^{440}$

Views rooted in his earliest and most sustained thinking about the law best account for Holmes's insensitivity to the free speech claims made by prewar scholars, by Hand in Masses, and by Stedman and Roe in their briefs for Debs. These libertarians insisted that the "bad tendency" theory could not support the democratic values protected by the first amendment. Holmes's contempt for "the dogma of equality" and his belief that law should sacrifice individual rights to the community's will did not predispose him to accept this libertarian ideology. ${ }^{41}$ On the contrary, the "clear and present danger" phrase in Schenck, like his other external measures of liability, translated into legal standards the deference to community will Holmes derived from his Social Darwinism. It is ironic that a test considered for decades to be a libertarian standard of first amendment interpretation originated in the view that the will of the majority, whether right or wrong, could limit individual freedom by imposing external standards of liability.

\section{E. The Confirming Evidence of Holmes's Correspondence}

Holmes's correspondence in 1918 and 1919 vividly confirms that the views he expressed in The Common Law directly influenced his approach to the Espionage Act cases. In June 1918-a year after Masses and nine months before Schenck, Frohwerk, and Debs-Hand and Holmes met by chance on a train and talked about "tolerance." Hand regretted that he "gave up" too easily during this conversation and wrote Holmes three days later to "take [his] stand." Hand advocated tolerance of dissent because opinions are "never absolutes"; they are "at best provisional hypotheses, incompletely tested." 442 "[F]ree speech," Holmes replied, "stands no differently than freedom from vaccination," 443 which

\footnotetext{
140 See generally Arnold, supra note 402, at 76 (concept of criminal attempt unworkable "without reference to the thing attempted").

"11 Holmes often refused to apply constitutional limitations to protect civil liberties. See Rogat, supra note 370, at 250; see also Rogat, Mr. Justice Holmes: A Dissenting Opinion (pts. 1 \& 2), 15 SxAN. L. REv. 3, 254 (1962-63) (analyzing Holmes's restrictive opinions in cases involving aliens and the Civil War amendments). His famous "right-privilege distinction" often provided the technical justification for this refusal. See generally Van Alstyne, The Demise of the Right-Privilege Distinction in Constitutional Law, 81 HaRv. L. REv. 1439 (1968).

142 Letter from Learned Hand to Oliver Wendell Holmes, Jr. (June 22, 1918) (Oliver Wendell Holmes, Jr., Papers, Box 43, Folder 30, Harvard Law School Library) [hereinafter cited as Holmes Papers], reprinted in Gunther, supra note 14, at 755-56, and in 1 HolmesLASKI LeTTERS 159 n.2 (M. Howe ed. 1953).

4s Letter from Oliver Wendell Holmes, Jr., to Learned Hand (June 24, 1918) (Hand
} 
the Supreme Court, in a decision joined by Holmes, had permitted a legislature to restrict through a law requiring compulsory vaccinations."44 Although people usually would not "care enough" to suppress speech, "if for any reason you did care enough you wouldn't care a damn for the suggestion that you were acting on a provisional hypothesis and might be wrong." 445 Holmes closed his letter to Hand by saying that he "used to define the truth as the majority vote of that nation that can lick all others. So we may define the present war as an inquiry concerning truth."

In the wake of his Espionage Act decisions less than a year after this exchange of letters with Hand, Holmes had a flurry of correspondence about free speech. He expressed serious reservations about the wisdom of the prosecutions under the Espionage Act. ${ }^{477} \mathrm{He}$ "greatly regretted"148 his "misfortune"448 in having the "disagreeable task" "40 of writing the opinions, and he suspected that the Chief Justice had assigned them to him in part because he favored free speech more than any of his colleagues. ${ }^{451}$ Particularly because the war had ended, he "wondered that the Government should press the [Debs] case to a hearing before us, as the inevitable result was that fools, knaves, and ignorant persons were bound to say he was convicted because he was a dangerous agitator and that obstructing the draft was a pretence."452 Holmes thought the federal judiciary had become "hysterical about the war,"453 and

Papers, supra note 357, Box 103, Folder 24), reprinted in Gunther, supra note 14, at 756-57. s4 Jacobson v. Massachusetts, 197 U.S. 11 (1905).

465 Letter from Holmes to Hand, supra note 443. After sharing Hand's letter with Harold Laski, Holmes reiterated this point: "In most matters of belief we are not cocksure - we don't care very much - and we are not certain of our power. But in the opposite case we should deal with the act of speech as we deal with any other overt act that we don't like." Letter from Oliver Wendell Holmes, Jr., to Harold Laski (July 16, 1918), reprinted in 1 HOLMES-LASKI LETTERS, supra note 442, at 160-61.

46 Letter from Holmes to Hand, supra note 443. Holmes apologized for his "levitical speech," id., but this letter did not indicate that he had changed his mind. Cf. O.W. Holmes, Natural Law, in Collected Legal Papers 310 (1920) (Holmes's definition of truth).

${ }^{117}$ Letter from Oliver Wendell Holmes, Jr., to Harold Laski (March 19, 1919), reprinted in 1 Holmes-LASKI LETTERS, supra note 442, at 189-90.

16 Id.

469 Letter from Oliver Wendell Holmes, Jr., to Sir Frederick Pollock (June 17, 1919), reprinted in 2 Holmes-Pollock LETTERS 14-15 (M. Howe ed. 1941).

4so Letter from Oliver Wendell Holmes, Jr., to Baroness Moncheur (April 4, 1919) (Holmes Papers, supra note 442, Box 36, Folder 4).

${ }^{181}$ Letter from Oliver Wendell Holmes, Jr., to Sir Frederick Pollock (April 5, 1919), reprinted in 2 HoLMEs-PoLLOCK LETTERS, supra note 449, at 7-8.

432 Id.; see letter from Holmes to Laski, supra note 447; letter from Holmes to Moncheur, supra note 450.

${ }^{453}$ Letter from Holmes to Laski, supra note 447. 
hoped that President Wilson would pardon many of those convicted. ${ }^{454}$ But as to the legal questions before the Supreme Court in Schenck, Frohwerk, and Debs, Holmes repeatedly emphasized that he had no doubts. ${ }^{455}$

Holmes maintained that the Espionage Act itself was constitutional, and even wise policy during the war, ${ }^{456}$ although he acknowledged that he had dealt "somewhat summarily" with the first amendment in the Espionage Act cases. ${ }^{457} \mathrm{He}$ declared himself generally "for aeration of all effervescing opinions-there is no way so quick for letting them get flat." During a war, however, he did not "think it unreasonable to say we won't have obstacles intentionally put in the way of raising troops-by persuasion any more than by force." 458

Holmes gave conflicting indications about how he would have voted had he been a member of the jury in Debs. Holmes seems to have told people what he thought they wanted to hear. ${ }^{459}$ Holmes did make clear, however, that his vote as a hypothetical juror was irrelevant to his role as a judge. As long as there was any evidence to support the jury findings, Holmes did not believe a judge could overturn them. Even when he conceded that the jury may have based its conviction of Debs on impermissible considerations, Holmes emphasized that he could not go behind the verdict. ${ }^{460}$

4bs Id.; letter from Oliver Wendell Holmes, Jr., to Sir Frederick Pollock (April 27, 1919), reprinted in 2 HoLMES-PoLLOCK LeTTERS, supra note 449, at 10-11.

185 See letter from Oliver Wendell Holmes, Jr., to Herbert Croly (May 12, 1919) (not mailed to Croly but enclosed with letter to Laski), reprinted in 1 HoLmes-Laski LETTERs, supra note 442, at 202-04; letter from Holmes to Laski, supra note 447; letter from Holmes to Moncheur, supra note 450; letter from Holmes to Pollock, supra note 454; letter from Oliver Wendell Holmes, Jr., to John P. Wigmore (June 7, 1919) (Holmes Papers, supra note 442, Box 36, Folder 4).

4SB Letter from Holmes to Croly, supra note 455; see letter from Holmes to Pollock, supra note 454 (Espionage Act constitutional).

${ }^{457}$ Letter from Holmes to Pollock, supra note 451.

${ }^{488}$ Letter from Holmes to Croly, supra note 455.

468 Mark Howe has observed that Holmes may have been "driven by an unusual longing for recognition," or "at least a strenuous eagerness for achievement, and perhaps an excess of anxiety for credit." M. HowE, supra note 370 , at 85.

Holmes wrote or left the impression with liberals that as a juror he would have voted to acquit Debs. See letter from Zechariah Chafee, Jr., to Judge Charles F. Amidon (Sept. 30, 1919) (Chafee Papers, supra note 189, Box 4, Folder 1); letter from Holmes to Croly, supra note 455; letter from Holmes to Laski, supra note 447. Yet in a letter to Dean Wigmore, Holmes gave his opinion that the jury finding was correct. Letter from Holmes to Wigmore, supra note 455. Wigmore subsequently blasted Holmes for his Abrams dissent. See Wigmore, Abrams v. U.S.: Freedom of Speech and Freedom of Thuggery in War-Time and Peace-Time, 14 ILL. L. REv. 539 (1920).

${ }^{180}$ See, e.g., letter from Holmes to Croly, supra note 455 ("I cannot doubt that there was evidence warranting a conviction on the disputed issues of fact."); letter from Holmes to 
Nor was Holmes moved by complaints that jury determinations of probable consequences undermined free speech. Stedman's petition for rehearing in Debs, which again advanced this argument, was unsuccessful, ${ }^{461}$ as were similar criticisms by Learned Hand and Ernst Freund. ${ }^{482}$

Within weeks of the Espionage Act decisions, Hand wrote Holmes again. Promising that his letter would be "positively my last appearance in the role of liberator," Hand expanded on the letter he had sent the previous summer. Hand did not agree that speech might be punished simply because "the result is known as likely to follow"; even a "reasonable forecast" of the effect of speech should not make the speaker liable. Hand observed that free speech "cases actually occur when men are excited" and that "juries are especially clannish groups[, which] . . . won't much regard the difference between the probable result of the words and the purposes of the utterer." As a matter of historical fact, Hand emphasized, the test of motive sanctioned by Holmes allowed juries to "intimidate" and "scare" many people who might have "moderate[d] the storms of popular feeling" in 1918. Although he doubted its future, Hand adhered instead to the test he set forth in Masses: that liability for speech begins when words are "directly an incitement." "463

Ernst Freund, whose prewar treatise, The Police Power, ${ }^{464}$ proposed a direct incitement 'standard that anticipated Hand's approach in Masses, ${ }^{485}$ wrote a more extensive critique of Debs in the May 3, 1919, issue of The New Republic. ${ }^{468}$ Freund accused Holmes of taking "the very essentials of the entire problem for granted." According to Freund, "to be permitted to agitate at your own peril, subject to a jury's guessing at motive, tendency and possible effect, makes the right of free speech a precarious gift." ${ }^{1487}$ Freund indicated that the Espionage Act itself was uncon-

Pollock, supra note 451 ("How it was with the jury of course I don't know."); see also letter from Chafee to Amidon, supra note 459.

461 Defendant's Petition for Rehearing at 2-4, Debs v. United States, 249 U.S. 211 (1919).

${ }^{482}$ See infra text accompanying notes 463-75.

18s Letter from Learned Hand to Oliver Wendell Holmes, Jr. (late Mar. 1919) (Holmes Papers, supra note 442, Box 43, Folder 30), reprinted in Gunther, supra note 14, at 758-59. "I bid a long farewell," Hand wrote toward the end of his letter, "to my little toy ship which set out quite bravely on the shortest voyage ever made." Id.

164 E. Freund, The Police Power (1904).

485 See Rabban, supra note 4, at 572.

168 Freund, supra note 14, reprinted in 40 U. CHI. L. REv. 239.

${ }^{467}$ Id. at 14 , reprinted in $40 \mathrm{U}$. CHI. L. REv. at 240. 
stitutional because it insulated from judicial review jury findings "of a conceivable psychological nexus between words and deeds." 468 The "checking function" of the jury, Freund added, may protect the people from unpopular exercises of governmental power, but it "fails where government policies are supported by majority opinion." ${ }^{469} \mathrm{He}$ was horrified that Holmes could not distinguish between shouting "fire" in a crowded theater and "political offenses." Freund concluded that Holmes's analysis of free speech must consist of "unsafe doctrine if it has to be made plausible by a parallel so manifestly inappropriate."470

Holmes responded to Hand with a puzzled letter in which he stated on three separate occasions that he did not see how Hand's direct incitement standard differed from his own test in Schenck. ${ }^{471}$ But Holmes had no such difficulties in recognizing

${ }^{483}$ Id. at 14 , reprinted in $40 \mathrm{U}$. CHI. L. REv. at 241 . This comment bears a striking resemblance to the criticisms by Theodore Schroeder, the principal figure in the Free Speech League, of punishing speech because of its speculative psychological tendency. See Rabban, supra note 4, at 577 \& n.346. Freund's subsequent commendation of Schroeder's writings to Chafee suggests that Freund's thinking on this subject had been influenced by Schroeder. See letter from Ernst Freund to Zechariah Chafee, Jr. (Aug. 13, 1919) (Chafee Papers, supra note 189, Box 14, Folder 10).

169 Freund, supra note 14, at 14, reprinted in $40 \mathrm{U}$. CHI. L. Rev. at 241 . A recent comprehensive article identifies the centrality of the "checking value" of the First Amendment, defined as "the value that free speech, a free press, and free assembly can serve in checking the abuse of power by public officials." Blasi, The Checking Value in First Amendment Theory, 1977 AM. B. Found. RESEARCH J. 523, 527.

${ }^{470}$ Freund, supra note 14, at 14, reprinted in $40 \mathrm{U}$. CHI. L. REv. at 241.

${ }^{471}$ Letter from Oliver Wendell Holmes, Jr., to Learned Hand (April 3, 1919) (Hand Papers, supra note 357, Box 103, Folder 24), reprinted in Gunther, supra note 14, at 759-60. Holmes correctly understood Hand to agree that an obstruction need not be successful in order to violate the Espionage Act. He incorrectly inferred, however, that this agreement precluded any inconsistencies between their approaches. Holmes apparently did not recognize that Hand, in a more restrained manner, had made essentially the same criticisms as Freund. Id.

Holmes's inability to understand his differences with Hand might have originated, at least in part, from Hand's statement: "I haven't a doubt that Debs was guilty under any rule conceivably applicable." Letter from Hand to Holmes, supra note 463. Gunther finds this comment "hard to credit" in light of the remainder of this letter, Hand's other correspondence, and the text of Masses. He attributes it to "Hand's extraordinary deference to Holmes" and views it "as an effort to seem to agree with the result while trying to persuade the master of the error of his reasoning." Gunther, supra note 14, at 739-40.

I suspect that this explanation, though plausible, is both incomplete and too generous to Hand. Hand, fearful of jeopardizing his valued relationship with Holmes, may have been more timid than respectful. It is also revealing that Hand, while subsequently praising Holmes's dissent in Abrams, thought the majority might have been correct "on the facts." Letter from Learned Hand to Zechariah Chafee, Jr. (Dec. 3, 1919) (Chafee Papers, supra note 189, Box 4, Folder 1), reprinted in Gunther, supra note 14, at 762-63. These statements are puzzling. Combined with his unnecessarily restrictive decisions in Nearing and Eastman, see supra notes 175.80 and accompanying text, they suggest that Hand may not 
Freund's pointed objections to his opinion in Debs. When Harold Laski asked if he had been "at all influenced"172 by Freund's article on Debs in The New Republic, Holmes replied that he "thought it rather poor stuff." He elaborated by enclosing with his response to Laski a letter he had drafted to Herbert Croly, the editor of The New Republic, but had decided not to send "as some themes may become burning." ${ }^{473}$ Holmes wrote in his draft to Croly that "Freund's objection to a jury 'guessing at motive, tendency and possible effect' is an objection to pretty much the whole body of law, which for thirty years I have made my brethren smile by insisting to be everywhere a matter of degree."174 Holmes cited earlier antitrust and criminal cases for support and quoted his previous statement that "the law is full of instances where a man's fate depends on his estimating rightly, that is, as the jury subsequently estimates it, from matters of degree." 475

This correspondence reinforces Holmes's subsequent letter to Chafee about the origins of the "clear and present danger" test. ${ }^{476}$ Even in the face of criticism from Hand and Freund, Holmes continued to rely on the fundamental and broadly applicable principles he had set forth in The Common Law and had applied during four decades as a judge to all areas of the law. The very example in Schenck that Freund perceptively found so inappropriate underscores Holmes's consistency. Indeed, Holmes may well have been thinking of the solicitation to light a fire in Peaslee when he wrote in Schenck that the first amendment would not protect "falsely shouting fire in a theatre."

\section{Zechariah Chafee, JR.: The Scholar as Advocate}

Zechariah Chafee's article, Freedom of Speech in War

have been as libertarian as his decision in Masses and much of his related correspondence might indicate. Perhaps the thinking that produced Hand's restrictive decision in United States v. Dennis, 183 F.2d 201 (2d Cir. 1950), aff'd, 341 U.S. 495 (1951), was taking shape even in the period when he wrote Masses.

${ }^{472}$ Letter from Harold Laski to Oliver Wendell Holmes, Jr. (March 18, 1919), reprinted in 1 Holmes-LASKI LeTTERS, supra note 442, at 201-02.

${ }^{473}$ Letter from Oliver Wendell Holmes, Jr., to Harold Laski (May 13, 1919), reprinted in 1 Holmes-LASKI LetTers, supra note 442, at 202.

474 Letter from Holmes to Croly, supra note 455.

175 Id. (citing Nash v. United States, 229 U.S. 373, 377 (1913) (Holmes, J.) (antitrust case)). After this sentence in Nash, Holmes cited for support two of his decisions as a state judge, Commonwealth v. Pierce, 138 Mass. 165, 178 (1884) (manslaughter case), and Commonwealth v. Chance, 174 Mass. 245, 252, 54 N.E. 551, 554 (1899) (murder case).

476 Letter from Holmes to Chafee, supra note 366.

477249 U.S. at 52. 
Time, ${ }^{478}$ was the most comprehensive and influential response to Holmes's Espionage Act decisions. Chafee made clear at the beginning of his article that he would not "confine" himself to a technical analysis of the Espionage Act. ${ }^{479} \mathrm{He}$ set as his "main task" an explanation of "the nature and scope of the policy which finds expression in the First Amendment," 480 a subject he had begun to explore in The New Republic ${ }^{\mathbf{8 1}}$ four months before Holmes decided Schenck, Frohwerk, and Debs. To accomplish this task, Chafee often found it "worth while to forsake the purely judicial discussion of free speech, and obtain light upon its meaning from the history of the constitutional clauses and from the purpose free speech serves in social and political life."482

Chafee had good strategic reasons to look beyond the law. Freedom of Speech in War Time was not a work of dispassionate scholarship. Horrified by the repression of free speech during World War I, Chafee had become a committed civil libertarian before he wrote this article. ${ }^{483}$ Not surprisingly, his published conclusions about the policy and purpose of the first amendment reflected his new-found libertarian ideology. But Chafee also allowed this ideology to distort his discussion of history and judicial precedent. Unlike Ernst Freund, who directly attacked Holmes's decision in Debs as inconsistent with a proper understanding of the policies embodied in the first amendment, ${ }^{484}$ and unlike several

${ }^{478}$ Chafee, Harvard, supra note 2.

479 Id. at 934.

480 Id. at 935.

482 Chafee, New Republic, supra note 2.

182 Chafee, Harvard, supra note 2, at 945.

${ }^{483}$ See Chafee, supra note 39; Prude, Portrait of a Civil Libertarian: The Faith and Fear of Zechariah Chafee, Jr., $60 \mathrm{~J}$. AM. Hist. 633, 634-38 (1973).

484 Freund, supra note 14, reprinted in 40 U. CHI. L. REv. 239; see supra text accompanying notes 464-70 (discussing Freund's criticisms of Holmes). Like Chafee, Freund maintained that "in the long run sound law cannot be inimical to sound policy." "A country can ill spare," he added, "the men who when waves of militant nationalism run high do not lose the courage of their convictions." Freund, supra note 14, at 15, reprinted in $40 \mathrm{U}$. CHI. L. REv. at 242. In response to a critique of his article in a subsequent issue of The New Republic, Freund defended his mixture of policy and law: "Where the Constitution establishes a political principle as it does in the First Amendment, it is inevitable that considerations of policy should be touched upon in discussing questions of law .... You cannot deal with the Espionage Act without having some notion of what the right of free discussion demands." 19 NEw REPUBLIC 151-52 (1919).

Freund made the mistake of concluding that American historical practice had been "so tolerant of political liberty" that there had been no occasion prior to the Espionage Act to apply the legal principles governing political speech. Freund, supra note 14, at 14, reprinted in $40 \mathrm{U}$. CHI. L. REv. at 240. Moreover, in his influential prewar treatise Freund did not criticize judicial decisions that tended to weaken some of his more optimistic conclusions about the condition of free expression in the United States. See Rabban, supra note 4, at 
prewar scholars who vociferously criticized restrictive decisions by their judicial contemporaries, ${ }^{485}$ Chafee tried within the limits of plausibility to conform history and precedent to his own interpretation of what the first amendment should mean. To do so, he often had to sacrifice scholarly accuracy to libertarian ideology. ${ }^{488}$ Written under the guise of scholarship, Freedom of Speech in War Time was essentially a work of propaganda. ${ }^{\mathbf{4 8 7}}$ Chafee's libertarian misconstruction of "clear and present danger" was but one example of his sacrifice of scholarship to ideology. ${ }^{488}$ Holmes, who in The Common Law had himself strained history to serve very different personal views on law and society, ${ }^{489}$ soon found it convenient to rely on Chafee's misconstruction of his own language in Schenck. ${ }^{400}$

\section{A. Chafee's Interpretation of the First Amendment}

Chafee considered the first amendment "a declaration of national policy in favor of the public discussion of all public questions." ${ }^{491} \mathrm{He}$ elaborated this most central position in a paragraph he privately described as "key":482

$562 \mathrm{n} .254,567-68 \mathrm{nn} .284-85$. But Freund never engaged in the misconstruction of history and precedent that often characterized Chafee's article. For example, Freund conceded that the framers did not intend to abolish the crime of seditious libel, although he did maintain that the first amendment should now be construed to preclude punishment for that crime. E. FreUnd, supra note 464, at 508; see id. at 569-70.

${ }^{485}$ See Rabban, supra note 4, at 561-62.

486 As a result of conservative opposition to his devastating and impassioned critique of the trial in the Abrams case, see Chafee, Contemporary State Trial, supra note 2, Chafee was "tried" in 1921 by a "Committee to Visit the Law School." See 35 Harv. L. Rev. 9-10 (1921). After this "trial," which absolved Chafee of any ccnscious errors, Chafee agreed to publish several corrections and further statements in the Harvard Law Review. Id. at 10-14; see Irons, "Fighting Fair": Zechariah Chafee, Jr., the Department of Justice, and the "Trial at the Harvard Club," 94 HaRv. L. Rev. 1205 (1981). See generally A. SutherLand, The LAw at Harvard 250-58 (1967). Chafee's main accuser had originally criticized him for alleged, though undefined, inaccuracies in Freedom of Speech in War Time, but eventually focused his attack on A Contemporary State Trial. Irons, supra, at 1213, 1228-30. Chafee's opponents were motivated by political rather than scholarly concerns; it is nevertheless of some historical interest that, judged solely by standards of accuracy, they picked on the wrong article.

${ }^{187}$ Cf. Prude, supra note 483, at 641-42 (Chafee's writings are "educational," appealing "less to technical legal precedent than to the pragmatic, commonsense considerations of self-interest.").

488 See infra text accompanying notes 551-66.

4BD See supra note 376 (describing Holmes's misleading use of history in The Common Law).

${ }^{100}$ See infra text accompanying notes 680-83.

401 Chafee, Harvard, supra note 2, at 934.

182 Statement of Zechariah Chafee, Jr., about his work on freedom of speech (Chafee 
The true meaning of freedom of speech seems to be this. One of the most important purposes of society and government is the discovery and spread of truth on subjects of general concern. This is possible only through absolutely unlimited discussion, for ... once force is thrown into the argument, it becomes a matter of chance whether it is thrown on the false side or the true, and truth loses all its natural advantage in the contest. Nevertheless, there are other purposes of government, such as order, the training of the young, protection against external aggression. Unlimited discussion sometimes interferes with these purposes, which must then be balanced against freedom of speech, but freedom of speech ought to weigh very heavily in the scale. The First Amendment gives binding force to this principle of political wisdom. ${ }^{493}$

As Chafee insisted in private correspondence, "a policy of sifting out truth" justifies the inevitable risk that speech may interfere with proper objectives. Following the approach of Hand in Masses, he acknowledged that "all discussion opposed to the government is bound to have some effect in delaying the progress of the war, however slight." Chafee, like Hand before him, concluded that "the first amendment was designed to insure that that risk should be taken."484

Chafee also argued that the repression of speech during World War I provided excellent empirical support for his position. He asserted that "an opponent makes the best cross-examiner" in public affairs as well as in legal proceedings. Recent history proved that it was a "disastrous mistake to limit criticism to those who favor[ed] the war."495 Anyone who discussed secret treaties during the war, Chafee pointed out, ran the risk of a jail term, but "[o]pen discussion would have made it impossible for the President to be ignorant of them until he went to Paris." ${ }^{496}$ War objectives, he added,

\footnotetext{
Papers, supra note 189, Box 29, Folder 22).

${ }^{193}$ Chafee, Harvard, supra note 2, at 956-57 (footnote omitted). The importance of this "key" paragraph to Chafee is emphasized by its verbatim appearance in his earlier New Republic article, Chafee, New Republic, supra note 2, at 67, and in his subsequent book, $\mathrm{Z}$. ChafeE, supra note 2 , at 34 .

496 Letter from Zechariah Chafee, Jr., to Alfred Bettman (Oct. 16, 1919) (Chafee Papers, supra note 189, Box 14, Folder 3); see supra text accompanying notes 158-62 (Hand's similar reasoning in Masses).

${ }^{285}$ Chafee, Harvard, supra note 2, at 958.

${ }^{488}$ Letter from Chafee to Bettman, supra note 494; see Chafee, Harvard, supra note 2, at 958-59.
} 
often change completely, as the fluctuating government positions during World War I amply illustrated. Chafee considered such reevaluations and reformulations of national policy healthy, and he maintained that they should be influenced by the freest possible expression of all divergent views. Chafee criticized the prevalent judicial construction of the Espionage Act for ignoring this social interest in the search for truth, and for regarding free speech "as merely an individual interest, which must readily give way like other personal desires the moment it interferes with the social interest in national safety." 497

\section{B. Chafee's Rejection of the "Bad Tendency" Test}

Chafee concluded that "the most essential element of free speech is the rejection of bad tendency as the test of a criminal utterance." ${ }^{488} \mathrm{He}$ observed that the application of this test by a jury rather than a judge protects popular attacks on government but has relatively little value for dissidents "in times of war or threatened disorder when the herd instinct runs strong." ${ }^{\mathbf{4 9 9}}$ For Chafee, the test of criminality was more important than the locus of decision. Rather than allocating the determination of "bad tendency" to the jury, he preferred the substitution of a more protective standard. "The real issue in every free-speech controversy," Chafee stressed, is "whether the state can punish all words which have some tendency, however remote, to bring about acts in violation of law, or only words which directly incite to acts in violation of law."

Chafee attempted throughout Freedom of Speech in War Time to demonstrate that the first amendment precluded the "bad tendency" test. He claimed, referring to the American colonial experience, that the men who wrote the first amendment "intended to wipe out the common law of sedition, and make further prosecu-

${ }^{407}$ Chafee, Harvard, supra note 2, at 959. He also alluded to "the national value of the opposition in former wars." Id.

198 Id. at 953. Chafee did not discuss the "bad tendency" test in his New Republic article, Chafee, New Republic, supra note 2, perhaps because he considered this topic too technical for a magazine with a general readership. But see supra text accompanying note 467 (Freund article in The New Republic criticizes "bad tendency" test).

${ }^{409}$ Chafee, Harvard, supra note 2, at 949. "Sedition prosecutions," Chafee pointed out, "went on with shameful severity in England after Fox's Libel Act had given the jury power to determine criminality." The discredited Sedition Act of 1798, he added, also "entrusted criminality to the jury." Id. at 948 (footnote omitted). Chafee cited the jury verdict in Debs as an illustration of this point, noting that the personal and economic backgrounds of the jurors made them particularly unsympathetic to Debs. Id. at 949 n.60.

${ }^{300}$ Id. at 948. 
tions for criticism of the government, without any incitement to law-breaking, forever impossible in the United States of America." that the free speech clause eradicated punishment of words "for a supposed bad tendency long before there is any probability that they will break out into unlawful acts" and abolished the doctrine of constructive intent, which infers "intent from the bad tendency of the words on the ground that a man is presumed to intend the consequences of his acts." of 1798 revived these doctrines, again reducing intent to an inference from the supposed "bad tendency" of words. ${ }^{503}$ Yet the law "proved so disastrous"s04 that this discredited approach was never again applied until 1917. ${ }^{.05}$ According to Chafee, "we can with certitude declare that the First Amendment forbids the punishment of words merely for their injurious tendencies."

Chafee maintained that the Espionage Act was constitutional on its face. ${ }^{507}$ Following Hand's lead in Masses, Chafee found "not a word in the 1917 Espionage Act to show that Congress did change the ordinary tests or make any speech criminal except false statements and incitement to overt acts." Masses applied the "normal"s09 and "ordinary" ing speech, whereas the reversal by the Second Circuit, perhaps unwittingly, ${ }^{511}$ established the "old-time doctrine of indirect causation in the minds of district judges throughout the country." The Second Circuit thereby rejected the "common-law test of incitement" and "deprived us of the only standard of criminal speech there was, since there had been no well-considered discussion of the meaning of free speech in the First Amendment." 113 most subsequent Espionage Act decisions, Chafee unhappily reported, "bad tendency has been the test of criminality."

\footnotetext{
so1 Id. at 947.

${ }^{602}$ Id. at 949 ; see id. at 951.

sos Id. at 952-53.

sot Id. at 953.

sos $I d$. at 952 .

${ }^{506}$ Id. at 960 .

${ }^{807} \mathrm{Id}$.

${ }^{508} \mathrm{Id}$. at 963.

${ }^{500} \mathrm{Id}$. at 961 .

${ }^{610} \mathrm{Id}$. at 963 .

B11 Id. at 964 n.108.

${ }^{512}$ Id. at 964 .

s13 Id.

${ }^{614} I d$. at 968 .
} 
judges "stemmed the tide," "large number of cases which ignore the clear meaning of the statute" as interpreted by Hand. ${ }^{\text {s16 }}$ Judicial misconstruction of the Espionage Act, Chafee complained, made its application worse than the Sedition Act of 1798 , which at least allowed truth as a defense. ${ }^{517}$

Chafee found hope, however, in Holmes's opinion in Schenck, particularly in its formulation of "clear and present danger." According to Chafee, this standard "substantially agrees" with Hand's opinion in Masses and with Chafee's own "investigation of the history and political purpose of the First Amendment." "1518 Holmes retreated in Debs by affirming the verdict based on the "natural tendency and reasonably probable effect" of speech, ${ }^{519}$ but Chafee remained confident that the "clear and present danger" standard would be "a good test for future free speech cases."

\section{Chafee's Misinterpretation of Legal History}

Chafee was correct in identifying the "bad tendency" test as the chief threat to his interpretation of the purpose and meaning of the first amendment. Yet his reconstruction of first amendment history to preclude the "bad tendency" test was inaccurate and misleading, often in ways that Chafee himself must have recognized. Chafee was on the safest ground in his discussion of the original meaning and early history of the first amendment; notwithstanding a subsequent major study maintaining that the framers did not intend the first amendment to abolish seditious libel or to require a direct incitement standard, ${ }^{\text {221 }}$ Chafee could rely for his

s1s $I d$. at 965 .

s16 Id. at 961 n.93.

517 Id. at 965 .

s18 Id. at 967 .

s19 Id. at 968 (emphasis in original).

${ }^{820}$ Id. at 969; cf. infra text accompanying notes 551-66 (discussing Chafee's interpretation of "clear and present danger").

321 L. LevY, Legacy of SUPpression (1960). Levy maintains that in interpreting the original meaning of the first amendment Chafee and others attempted to "recreate" the past "so that its image may be seen in a manner consistent with our rhetorical tradition of freedom, thereby yielding a message which will instruct the present." Id. at 2-3. Though directed toward Chafee's discussion of the framers' intent, Levy's observation applies equally well to Chafee's treatment of more recent first amendment history, including the Espionage Act decisions.

Some scholars have questioned Levy's conclusions about the framers' original understanding of the first amendment. A recent comprehensive article challenges Levy's interpretation of the press clause and helps resuscitate Chafee's earlier views. Anderson, The Origins of the Press Clause, 30 U.C.L.A. L. REv. 455 (1983); see also Kalven, The New York 
contrary interpretation on several important scholars who wrote just prior to World War I. ${ }^{\mathbf{5 2}}$

Chafee's interpretation of later developments and the Espionage Act cases, however, could not be supported. Chafee was clearly aware of the prewar tradition of judicial hostility to free speech that often relied on the "bad tendency" test he claimed had disappeared after the demise of the Sedition Act of 1798. The prewar scholars, cited by Chafee to support his analysis of the purpose and history of the first amendment, ${ }^{, 23}$ themselves criticized the reliance of contemporary judicial decisions on the "bad tendency" test to reject free speech claims. ${ }^{624}$ Moreover, Chafee himself had read these decisions. ${ }^{525}$ His general neglect of them while asserting that they were not sufficiently rigorous or plentiful "to develop any definite boundary between lawful and unlawful speech"126 promoted the historical fiction that the "failure" of prior courts left the federal judges who decided the Espionage Act cases without any standards of first amendment interpretation. This fiction allowed Chafee to make the false claim that these judges were able "to impose standards of their own"s2z and promote a "revival of the doctrines of indirect causation and constructive intent."

\section{The Meaning of the Common Law}

Having read the restrictive prewar decisions, Chafee was also inaccurate in asserting that Hand's direct incitement test was the "ordinary" standard at common law. Hand himself, while discussing in Masses the "normal" role of free speech in a democracy, did not claim the support of the common law. ${ }^{629}$ Hand's test originated in the values he derived from his readings in philosophy and political theory. His discussion of history in Masses "was essentially im-

Times Case: A Note On "The Central Meaning Of The First Amendment", 1964 Sup. CT. REv. 191, 221 n.124; Anastaplo, Book Review, 39 N.Y.U. L. REv. 735 (1964).

${ }^{822}$ See Rabban, supra note 4 , at $586-87$ (observing Chafee's reliance on prewar scholars).

${ }^{823}$ See id. at 586-89.

524 See id. at 559-79 (discussing views of prewar scholars).

${ }^{525}$ Chafee, supra note 39 , at 2.

${ }^{828}$ Chafee, Harvard, supra note 2, at 944.

${ }^{827}$ Id. at 959.

${ }^{823}$ Id. at 965 .

${ }^{829}$ See 244 F. at 539-40. In United States v. Nearing, 252 F. 223, 227-28 (S.D.N.Y. 1918), however, Hand did claim that the common law supported his Masses standard and that the reversal of Masses by the Second Circuit required "an added measure of criminal liability." Id. 
pressionistic." ${ }^{330}$ Indeed, when faced with writing the Masses decision Hand was concerned that he "didn't know anything about the history of the subject" and had to "fire off" his "own funny ideas about what ought or oughtn't to be."331 After reading Chafee's book, Hand realized "it was well that I knew no more than I did. Like the heathen I was saved by my invincible ignorance."532 Moreover, Ernst Freund, whose prewar treatise foreshadowed Hand's decision in Masses in its advocacy of the direct incitement standard, ${ }^{\text {,33 }}$ claimed that the Espionage Act itself "revives and perpetuates the defects of the common law."'s34 Freund objected to any application of "the notoriously loose common law doctrines of conspiracy and incitement to offenses of a political character."

Nonetheless, Chafee adhered to his claim that Hand in Masses and Holmes in Schenck were simply restating traditional commonlaw doctrine. Chafee's views are best revealed in his important exchange of correspondence with Alfred Bettman, the lawyer who had written the government's briefs in Schenck, Sugarman, Frohwerk, and Debs. ${ }^{538}$ Bettman wrote Chafee in September 1919 to congratulate him on the publication of Freedom of Speech in War Time and "to state that I agree most heartily with all that you say, subject to a few points." Bettman identified as a "doubtful point" a conclusion which he considered implicit in Chafee's article and which he had already rebutted in his reply to Roe in Debs. ${ }^{537}$ Bettman understood Chafee to maintain that the likelihood of jury verdicts of guilty in Espionage Act prosecutions ren-

${ }^{8 s 0}$ Gunther, supra note 14 , at 727 ; see id. at 740 .

ss1 Letter from Learned Hand to Zechariah Chafee, Jr. (Dec. 3, 1920) (Chafee Papers, supra note 189, Box 4, Folder 20), reprinted in Gunther, supra note 14, at 768.

${ }^{s 32}$ Letter from Learned Hand to Zechariah Chafee, Jr. (Jan. 2, 1921) (Chafee Papers, supra note 189, Box 4, Folder 20), reprinted in Gunther, supra note 14, at 769.

ss3 See supra text accompanying notes 464-65.

ss4 Freund, supra note 14, at 14, reprinted in 40 U. CHI. L. Rev. at 241.

${ }^{33 s}$ Id. at 6, reprinted in $40 \mathrm{U}$. CHI. L. Rev. at 240 . In The Police Power, see supra note 464, Freund identified his direct incitement standard with "the principles of the common law." He cited only one case for support. Id. at 510 (citing Spies v. People, 122 Ill. 1, 12 N.E. 865 , aff'd on other grounds, 123 U.S. 131 (1887)). Freund apparently changed his mind about the meaning of the common law between the publications of his treatise and his article on the Debs case, perhaps because so many decisions in the intervening years had applied the "bad tendency" test. See Rabban, supra note 4, at 533-36, 543-48 (discussing judicial reliance on "bad tendency" test).

sss Bettman reported that during the war he had been "in immediate charge" of the prosecutions under the Espionage Act and had written many of the briefs "(subject, of course, to some touching up by my immediate chief, Mr. O'Brian)." Letter from Alfred Bettman to Zechariah Chafee, Jr. (Sept. 20, 1919) (Chafee Papers, supra note 189, Box 14, Folder 3).

s37 See supra text accompanying notes 286-89 (discussing Bettman's reply to Roe). 
dered unconstitutional an otherwise constitutional law. "The principle of indirect causation or presumptive intent," Bettman stressed in rejecting this view, "are [sic] a part of the criminal law, and I do not see how the First Amendment can be construed as eliminating, without express legislative decree, those accepted general principles of the criminal law in cases based upon verbal or written utterances." Whether an exception to this rule should be granted "to a particular class of cases," based on the probability of erroneous jury verdicts or other considerations, is "a question of legislative policy and not constitutional law." $" 538$

In a subsequent letter, Bettman even acknowledged that a constitutional provision restraining jury discretion might be needed, but he denied that the first amendment could be interpreted to serve this function. "That the individual needed protection against the jury," he added, "was a thought which could hardly have occurred to the framers of the amendment." Bettman believed that the constitutional guarantee of free speech should "unquestionably" prevent any legislative attempt "to suppress the absolutely free discussion of past, present and future governmental policies" and officials, and admitted that many Espionage Act convictions violated this conception of the first amendment. ${ }^{539} \mathrm{He}$ criticized federal judges in some of these cases for having "lost their heads," for giving "unfair charges," and for not exercising sufficient "control over the juries." " $\mathrm{He}$ hoped that in at least one of the Espionage Act cases still pending the Supreme Court would hand down a decision that "will assist the Department of Justice during the next war in counteracting the pressure of public intolerance." ${ }^{611}$ But Bettman maintained that neither criminal nor constitutional law mandated restrictions on jury determinations of presumptive intent.

Chafee remained unconvinced. In his response to Bettman, he elaborated the interpretation he had set forth in his article. ${ }^{\mathbf{5 4 2}}$

${ }^{53 s}$ Letter from Bettman to Chafee, supra note 536.

${ }^{839}$ Letter from Alfred Bettman to Zechariah Chafee, Jr. (Oct. 27, 1919) (Chafee Papers, supra note 189, Box 14, Folder 3).

$540 \mathrm{Id}$.

${ }_{541}$ Id. Bettman cited Ex parte Milligan, 71 U.S. (4 Wall.) 2 (1866) (prohibiting suspension of writ of habeas corpus), as the case that served this purpose after the Civil War. Letter from Bettman to Chafee, supra note 539. Judge Amidon made a similar point. "We were in need of something which should have been as corrective in the case of the present war," he wrote Chafee, "as Ex Parte Milligan was in the case of the Civil War." Letter from Judge Charles F. Amidon to Zechariah Chafee, Jr. (June 5, 1920) (Chafee Papers, supra note 189 , Box 4, Folder 1).

${ }^{342}$ Letter from Chafee to Bettman, supra note 494. 
Chafee acknowledged that the first amendment did not "eliminate the ordinary principles of the common law with regard to utterances." Yet in a confused discussion of doctrine, Chafee disagreed with Bettman's view that "the principle of indirect causation is part of the criminal common law relating to utterance." Chafee recognized that "there is always a chain of possible events between an utterance and actual interference with the activities of government," and added that the test of criminality is "just a question of degree how short that chain must be." Chafee concluded that the "common law has fixed that point with reasonable certainty at the place where the utterance furnishes a clear and present danger of a criminal act, to use the language of Justice Holmes in the Schenck case." He even conceded that the common law allowed presumptions of intent from the character of acts. But Chafee rejected, as a deviation from the common law, any test of causation based on "the natural and reasonably probable effect of the utterances."543 $\mathrm{He}$ seemed to equate direct incitement with direct causation. Chafee, like Holmes, ${ }^{544}$ failed to recognize that Hand's direct incitement test, by focusing on words rather than on probable effects, differed significantly from the test of "clear and present danger." "545

Whatever the confusion caused by his erroneous conflation of the very different views of Hand and Holmes, Chafee persisted in his misinterpretation of the common law. Even after a Harvard Law Review note, ${ }^{548}$ which Chafee himself considered "able and thoughtful," "s47 pointed out that the test of "natural tendency and reasonably probable effect" was neither unusual nor "inherently vicious," ${ }^{448}$ and after Holmes remarked in his dissent in Abrams that the word intent was "vaguely used in ordinary legal discussion," ${ }^{499}$ Chafee still insisted that "the ordinary language of criminal solicitation and attempt" precludes reliance on "remote bad

\footnotetext{
s43 Id.

s44 See supra text accompanying note 471 (Holmes's difficulty in understanding Hand's alternative views on free speech).

${ }^{\text {st5 }}$ But see infra note 594 and text accompanying notes 594-601 (Chafee's eventual recognition of difference between views of Hand and Holmes).

36 Note, The Espionage Act and the Limits of Legal Toleration, 33 HaRv. L. Rev. 442 (1920).

s17 Chafee, Contemporary State Trial, supra note 2, at 771.

s4s Note, supra note 546, at 443 . This note criticized the conception of the first amendment expressed by Chafee in Freedom of Speech in War Time, and concluded that the final determination of any test of the criminality of speech might "safely be left" with the jury. Id. at 446-48.
}

so Abrams v. United States, 250 U.S. 616, 626 (1920) (Holmes, J., dissenting). 
tendency and possible incidental consequences."

E. Chafee and the Creation of the Libertarian Myth About "Clear and Present Danger"

After freeing himself from the burdens of history and precedent, Chafee, with even more ingenuity and disingenuousness, developed his clever and erroneous interpretation of "clear and present danger." Chafee opened his analysis of the four Espionage Act cases decided by the Supreme Court in March 1919 with the shockingly inaccurate statement that Sugarman, Schenck, and Frohwerk "were clear cases of incitement to resist the draft, so that no real question of free speech arose." the facts of any of these cases; to have done so would have undermined this crucial conclusion. Chafee then focused on Schenck, which on its facts presented the weakest free speech claim, ${ }^{562}$ because it contained Holmes's "fullest discussion"s53 of the first amendment.

Chafee quoted much of the crucial final paragraph of Schenck. He maintained that this quotation, especially the sentence containing the phrase "clear and present danger," "substantially agrees" with the libertarian interpretation of free speech he had already set forth earlier in his article. Chafee admitted:

It is unfortunate that 'the substantive evils' are not more specifically defined, but if they mean overt acts of interference with the war, then Justice Holmes draws the boundary line very close to the test of incitement at common law and clearly makes the punishment of words for their bad tendency impossible. .54

Chafee did not explain why the definition of substantive evils as overt acts of interference with the war entails the substitution of an incitement test for the "bad tendency" approach. For the remainder of his analysis, moreover, Chafee neglected this provisional "if" and assumed that Holmes did conceive of "clear and present danger" as a libertarian replacement for "bad tendency." Chafee provided no support for his assumption that Holmes actu-

${ }^{8 s 0}$ Chafee, Contemporary State Trial, supra note 2, at 770; cf. id. at 773 (objecting to "bad tendency" as "test of criminality").

${ }^{s 51}$ Chafee, Harvard, supra note 2, at 967 (footnote omitted).

${ }^{852}$ See supra text accompanying note 319 .

sss Chafee, Harvard, supra note 2, at 967.

${ }^{\circ s} I d$. (emphasis added). 
ally meant what Chafee said he might have meant, except to cite Peaslee. ${ }^{\mathrm{ss}}$ Chafee maintained that in using the words "proximity and degree" in Schenck as well as in Peaslee, Holmes recognized "the close relation between free speech and criminal attempts." In Chafee's view, Peaslee held that attempts "must come dangerously near success" to be punished. ${ }^{.57}$ But the Peaslee opinion itself stated only that the issue is whether they "come near enough to the accomplishment of the substantive offense," a determination which "may vary with circumstances." throughout all his discussions of criminal attempts that the seriousness of the threatened crime, whether a fire, a murder, or an obstruction of the war effort, is a crucial circumstance. ${ }^{569}$ In any event, attention to the probable effects of speech, however direct the relationship between speech and crime, is essentially a variant of the "bad tendency" test.

After reading an unjustifiable libertarian meaning into "clear and present danger" and identifying it as the "Supreme Court test," Chafee characterized Debs as a deviation from this proper standard. If Holmes had applied the "clear and present danger" test in Debs, Chafee maintained, "it is hard to see how he could have been held guilty." "562 Chafee also recognized that Holmes, by accepting "the verdict as proof that actual interference with the war was intended and was the proximate effect of the words used," had allowed Debs to be convicted "merely because the jury thought his speech had a tendency to bring about resistance to the draft." "I8s "If the Supreme Court test is to mean anything more than a passing observation," Chafee concluded, "it must be used to upset convictions for words when the trial judge did not insist that they must create 'a clear and present danger' of overt acts." 564

Chafee did not analyze Frohwerk at all, perhaps to avoid having to explain away another embarrassing "deviation" from the "clear and present danger" standard. It is ironic as well as fitting that a comment by Bettman underlines Chafee's devious treatment

\footnotetext{
sss Id. (citing Commonwealth v. Peaslee, 177 Mass. 267, 59 N.E. 55 (1901)).

sse Chafee, Harvard, supra note 2 at 967.

857 Id. at 963.

sss 177 Mass. at 271-72, 59 N.E. at 56.

ss8 See supra text accompanying notes $406,420,438-39$.

${ }^{860}$ See Gunther, supra note 14, at 720-21, 724.

s61 Chafee, Harvard, supra note 2, at 968.

sex Id. at 967-68.

ses Id. at 968.

sos Id.
} 
of Frohwerk. Bettman, even while defending the legal standards Holmes applied in Debs, maintained that "Frohwerk is one of the clearest examples of the political prisoner." Frohwerk's articles, Bettman wrote Chafee, were clearly "an advocacy of a change in governmental policy as distinguished from advocacy of obstruction of existing governmental policy, and seemed to me therefore to fall within the protection of the constitutional guaranty of free speech and press." Bettman was puzzled that Chafee cited Frohwerk as a case in which the first amendment was not involved, "in other words, as one of the justified convictions." to Frohwerk would have made it even harder for Chafee to maintain that "clear and present danger" was "anything more than a passing observation" in elaboration of the "bad tendency" test that he claimed Holmes had rejected by using this phrase. ${ }^{566}$

\section{F. Chafee as Advocate}

Chafee's libertarian understanding of the first amendment made much of his writing more hortatory and argumentative than objective and analytical. Freedom of Speech in War Time often reads more like a legal brief, or even a sermon, than a law review article. In the last paragraph of his article, the appearance of scholarly restraint that Chafee had tried, with varying degrees of success, to maintain gave way to a moving statement of his strong libertarian values:

Those who gave their lives for freedom would be the last to thank us for throwing aside so lightly the great traditions of our race. Not satisfied to have justice and almost all the people with our cause, we insisted on an artificial unanimity of opinion behind the war. Keen intellectual grasp of the President's aims by the nation at large was very difficult when the opponents of his idealism ranged unchecked while the men who urged greater idealism went to prison. In our efforts to silence those who advocated peace without victory we prevented at the very start that vigorous threshing out of fundamentals which might to-day have saved us from a victory without peace. ${ }^{567}$

Perhaps because he found himself writing less as a scholar

${ }^{885}$ Letter from Bettman to Chafee, supra note 539.

${ }^{688}$ Perhaps chastened by Bettman's comment, Chafee did discuss Frohwerk in his book. See Z. Chafee, supra note 2, at 15-16, 88, 90.

${ }^{867}$ Chafee, Harvard, supra note 2, at 973. 
than as an advocate of civil liberty, Chafee emphasized throughout his article his reliance on policy as well as on law. Probably for the same reason, he often left ambiguous the extent to which any particular argument was based on either. At times, Chafee seemed to equate the two. In his "key" paragraph, Chafee claimed that the first amendment gives "binding force" to "political wisdom." "se8 Later, in declaring that the first amendment precludes the "bad tendency" test, Chafee confidently maintained that the "history of the Amendment and the political function of free speech corroborate each other and make this conclusion plain." quently, Chafee resorted to independent arguments from policy to reinforce his legal analysis. Near the beginning of his article, he stated his intention to look beyond purely constitutional issues. The first amendment, he suggested, not only establishes the constitutional boundaries of free speech, but also serves as "an exhortation and a guide for the action of Congress inside that boundary." The fundamental policies embodied in the first amendment "should make Congress reluctant and careful in the enactment of all restrictions upon utterance, even though the courts will not refuse to enforce them as unconstitutional."

As part of an effort "to cover his bet on the intention of the framers," "b71 Chafee maintained that "the meaning of the First Amendment did not crystallize in 1791," but had developed over time. ${ }^{572}$ "The framers," Chafee acknowledged, "would probably have been horrified at the thought of protecting books by Darwin or Bernard Shaw, but 'liberty of speech' is no more confined to the speech they thought permissible than 'commerce' in another clause is limited to the sailing vessels and horse-drawn vehicles of 1787." 573 "Whether or not the Sedition Act was unconstitutional,"

s68 Id. at 957; see supra notes $492-93$ and accompanying text (quoting "key" paragraph).

ses Chafee, Harvard, supra note 2, at 960.

s70 Id. at 934.

571 Auerbach, The Patrician as Libertarian: Zechariah Chafee, Jr. and Freedom of Speech, 42 New Eng. Q. 511, 522 (1969). "For Chafee," Auerbach adds, "the contemporary social interest in freedom of expression was a more compelling justification than the historical evidence which he took to substantiate the validity of his position." Id. at 523 .

${ }^{372}$ Chafee, Harvard, supra note 2, at 954.

s73 Id. at 954-55. Chafee cited Holmes to support his statement about the growth of the law. Id. at $955 \&$ n.73 (citing Gompers v. United States, 233 U.S. 604, 610 (1914)). Chafee even admitted that "people in general at the time these guarantees were framed had no very definite idea of what they meant, and so were frequently swayed by the passion of the moment or by English precedents, which should have had no application to American conditions." Letter from Zechariah Chafee, Jr., to Edward S. Corwin (Jan. 3, 1921) (Chafee Papers, supra note 189, Box 14, Folder 7); cf. Chafee, Book Review, 62 HaRv. L. Rev. 891, 898 
Chafee also asserted (after making clear his own view that it was), "it surely defeated the fundamental policy of the First Amendment, the open discussion of public affairs." "574 Similarly, after minimizing the importance of prewar free speech cases, Chafee warned that many of them "seem to ignore so seriously the economic and political facts of our time, that they are precedents of very dubious value." 575 And, while maintaining that the language of the Espionage Act was constitutional, he reiterated that "freedom of speech is not only a limit on Congressional power, but a policy to be observed by the courts in applying constitutional statutes to utterance." $"$ "576

Neither did Chafee think that current understandings should limit the meaning of the first amendment. In response to Edward S. Corwin's defense of jury determinations of "bad tendency," he argued that "to give the Constitution a real meaning, it is necessary to look at the functional value of freedom of speech and not merely at contemporary practice." Learned Hand that even the "best test we can find . . . will sometimes break down," making "channels outside the law" the ultimate safeguard for free speech. Chafee's goal, he informed Hand, was "to produce greater tolerance in Judges and jurors and the public at large, so that when the next emergency arises we shall be better prepared . . . " ter understood as an effort toward that goal than as a work of conventional scholarship. ${ }^{\text {s79 }}$

Chafee's advocacy of his erroneous interpretation of "clear and

(1949) (reviewing A. Metklejohn, supra note 14) ("framers had no very clear idea as to what they meant by 'the freedom of speech or of the press" ") [hereinafter cited as Chafee, Book Review].

574 Chafee, Harvard, supra note 2, at 953.

B7s Id. at 944-45.

${ }^{328} I d$. at 960.

s77 Letter from Chafee to Corwin, supra note 573.

${ }^{878}$ Letter from Zechariah Chafee, Jr., to Learned Hand (March 28, 1921) (Hand Papers, supra note 357, Box 15, Folder 26), reprinted in Gunther, supra note 14, at 773.

s78 "In endeavoring to oppose suppressive measures," Chafee wrote in 1949, "I have found it best to keep on the level of wisdom and policy as much as possible. . . . The First Amendment comes into the discussion chiefly as a powerful means of persuasion. If persuasion fails, then the First Amendment will be invoked in the courts, but that is a last resort." Chafee, Book Review, supra note 573, at 894. Chafee criticized Meiklejohn for placing all his opposition to suppression "on a constitutional position which is extremely dubious." Id. This characterization certainly applies to Chafee's own construction of "clear and present danger," although, as the discussion in the text indicates, Chafee did not place his entire argument on constitutional ground. But neither did Meiklejohn rely exclusively on the Constitution. 
present danger" is the most important and dramatic evidence of his campaign for a more libertarian conception of the first amendment. Chafee apparently made a conscious and pragmatic decision to become a propagandist for the most libertarian construction he could derive from Justice Holmes's Espionage Act decisions even though he personally favored the approach used by Learned Hand in Masses, the opinion that helped start him on his free speech work. $^{.80}$ In Freedom of Speech in War Time, Chafee gave Hand lavish praise for his decision in Masses, calling him "the judge who has given the fullest attention to the meaning of free speech during the war." "s81 After analyzing Masses at length, Chafee concluded that " $[t]$ here is no finer judicial statement of the right of free speech." ${ }^{582} \mathrm{He}$ later dedicated Freedom of Speech to Learned Hand. ${ }^{583}$

Chafee's praise of Holmes was much more restrained. He found it "regrettable that Justice Holmes did nothing to emphasize the social interest behind free speech, and show the need of balancing even in war time." may render illegal otherwise permissible speech, Chafee observed, was a vestige of Holmes's belief that force defined truth. Chafee disagreed: "It is not by giving way to force and the majority that truth has been won." Holmes's "liberalism," he wrote, "seems held in abeyance by his belief in the relativity of values."

Despite these reservations, Chafee never wavered from his adherence to "clear and present danger." the generally "inconclusive"s8z nature of the Supreme Court's Espionage Act decisions, he confidently asserted that if this standard

6so Letter from Zechariah Chafee, Jr., to Learned Hand (Oct. 25, 1920) (Hand Papers, supra note 357, Box 15, Folder 26), reprinted in Gunther, supra note 14, at 766-77.

"s: Chafee, Harvard, supra note 2, at 960.

ss2 Id. at 962.

sss Z. Charge, supra note 2, at iii; cf. letter from Chafee to Hand, supra note 580 (asking Hand for permission to dedicate book to him).

sot Chafee, Harvard, supra note 2, at 968. To the argument that "freedom of speech cannot be invoked to break down the war power," Chafee responded:

[T] he First Amendment is just as much a part of the Constitution as the war clauses, and ... it is equally accurate to say that the war clauses cannot be invoked to break down freedom of speech. The truth is that all provisions of the Constitution must be construed together so as to limit each other.

Id. at 955.

sss Id. at 969. Chafee cited a current article by Holmes, Natural Law, supra note 446, which repeats without citation some basic themes from The Common Law.

sss See, e.g., Chafee, Harvard, supra note 2, at 969 ("clear and present danger" a "good test for future free speech cases").

ssr Id. 
had been announced in the summer of 1917, rather than in the spring of 1919, "there would have been many more acquittals" after Espionage Act prosecutions in the lower federal courts. ${ }^{588}$

Chafee tried to bolster his misconstruction of "clear and present danger" by assimilating it to Hand's incitement standard. ${ }^{589}$ At one point in his article, Chafee accurately concluded that Hand's test in Masses "places outside the limits of free speech one who counsels or advises others to violate existing laws." Chafee incorrectly stated at another point that this test would punish speech where there is "strong danger that it will cause injurious acts." ${ }^{591}$ In his article, as in his letter to Bettman, ${ }^{592}$ Chafee distorted Hand's objective standard "based on the nature of the utterance itself"sos into a requirement that the relationship between words and actions be immediate and direct. As a result, Chafee was able to equate Schenck and Masses and to cite both in support of his own fundamental opposition to the "bad tendency" test of indirect causation.

Despite this forced assimilation of Schenck to Masses, Chafee acknowledged throughout his career both that Holmes's "clear and present danger" language could not be entirely reconciled with Hand's incitement standard and that Hand's approach was better as well as different. Hand wrote Chafee just after he finished reading Freedom of Speech ${ }^{594}$ to clarify the difference Hand had always recognized between himself and Holmes:

I am not wholly in love with Holmesy's test and the reason is this. Once you admit that the matter is one of degree, while you may put it where it genuinely belongs, you so obviously make it a matter of administration, i.e., you give to Tomdick-

sss Id. at 968.

s89 See supra text accompanying note 518 .

${ }^{800}$ Chafee, Harvard, supra note 2, at 962.

s91 Id. at 961 .

s82 See supra text accompanying notes 544-45.

s93 Letter from Learned Hand to Zechariah Chafee, Jr. (Jan. 8, 1920) (Chafee Papers, supra note 189, Box 4, Folder 20), reprinted in Gunther, supra note 14, at 764-66.

s94 Freedom of Speech itself was more frank than Freedom of Speech in War Time in acknowledging the differences between Hand and Holmes. In language inserted into his earlier discussion of the Espionage Act cases, perhaps responding to correspondence from Hand himself, see supra note 593, Chafee pointed out, "Justice Holmes interprets the Espionage Act more widely than Judge Hand, in making the nature of the words only one element of danger, and in not requiring that utterances shall in themselves satisfy an objective standard. Thus he loses the great administrative advantages of Judge Hand's test." Z. Charee, supra note 2, at 89. Chafee did not retreat, however, from his defense of "clear and present danger." Compare id. with Chafee, Harvard, supra note 2, at 967. 
andharry, D.J., so much latitude [Hand here wrote and struck out "as his own fears may require"] that the jig is at once up. Besides their Ineffabilities, the Nine Elder Statesmen, have not shown themselves wholly immune from the "herd instinct" and what seems "immediate and direct" to-day may seem very remote next year even though the circumstances surrounding the utterance be unchanged. I own I should prefer a qualitative formula, hard, conventional, difficult to evade. ${ }^{585}$

"I agree with you," Chafee wrote in response, "that Holmes' distinction would prove unworkable in many cases. The Jury would go over it rough shod." Hand's test, Chafee added, "is surely easier to apply." der Meiklejohn, Chafee acknowledged the importance and distinctiveness of Hand's approach in Masses, and indicated his continuing preference for the incitement standard over Holmes's "clear and present danger" test. ${ }^{597}$ Chafee was even more direct in his Thirty-Five Years with Freedom of Speech, where he wrote: "I still like better Judge Learned Hand's phrase . . . 'direct incitement to violent resistance.' "'688

Chafee may not have fully appreciated all the contrasts in the positions of Holmes and Hand, ${ }^{609}$ but he did recognize that they had significantly different views on free speech, and he retained a lifelong preference for Hand's. Chafee must have decided that the best chance of obtaining judicial support for this view was to argue from language already accepted by a unanimous Supreme Court rather than to promote a better standard, which, as its author himself realized, had "met with almost unanimous disapproval by other Federal judges," Court. ${ }^{601}$

Hand indicated his own approval of Chafee's approach after reading Freedom of Speech: "You have, I dare say, done well to

sos Letter from Hand to Chafee, supra note 532.

${ }^{\text {Bos }}$ Letter from Chafee to Hand, supra note 578; see supra note 594 and accompanying text.

${ }^{307}$ Letter from Zechariah Chafee, Jr., to Alexander Meiklejohn (Nov. 23, 1948) (Chafee Papers, supra note 189, Box 2, Folder 16), quoted in part in Gunther, supra note 14, at 747 n.153.

${ }^{308}$ Chafee, supra note 39 , at 8-9.

sor See supra text accompanying notes 542-45, 592-93.

${ }^{000}$ Letter from Hand to Chafee, supra note 593.

so1 See supra notes 309-63 and accompanying text (discussing Schenck, Frohwerk, and Debs). 
take what has fallen from Heaven and insist that it is manna rather than to set up any independent solution." ${ }^{102}$ Chafee acknowledged his pragmatic motivation in less explicit terms by replying that "we ought to take the best test we can find even though it will sometimes break down." ${ }^{103}$ A generation later Chafee seemed to suggest that Holmes himself had made a similar pragmatic compromise in writing Schenck, Frohwerk, and Debs. He wrote Meiklejohn in 1948 that "Holmes could not possibly have convinced his colleagues that all speech which tended to produce evasion of the draft was immune." In any event, Chafee remained certain that these decisions, whether an expression of Holmes's personal views or the best he could get his colleagues to accept, had "saved" the United States from the excesses of most Espionage Act prosecutions and opinions and had "kept down suppression during World War II." public support for a standard whose weaknesses he acknowledged in private is the most striking manifestation of the pragmatism that lay behind his entire approach to the first amendment. ${ }^{605}$

Chafee's transformation of "clear and present danger" was adopted almost immediately by Justices Holmes and Brandeis. By the time Holmes wrote his Abrams dissent in November 1919, just

${ }^{602}$ Letter from Hand to Chafee, supra note 532.

${ }^{30}$ Letter from Chafee to Hand, supra note 578.

${ }^{804}$ Letter from Chafee to Meiklejohn, supra note 597. Chafee repeated this point in his review of Meiklejohn's book, Chafee, Book Review, supra note 573. Chafee, the lawyer, condescended to Meiklejohn, the philosopher:

Even if Holmes had agreed with Mr. Meiklejohn's view of the First Amendment, his insistence on such absolutism would not have persuaded a single colleague, and scores of men would have gone to prison who have been speaking freely for three decades. After all, a judge who is trying to establish a doctrine which the Supreme Court will promulgate as law cannot write like a solitary philosopher. He has to convince at least four men in a specific group and convince them very soon. The true alternative to Holmes's view of the First Amendment was not at all the perfect immunity for public discussion which Mr. Meiklejohn desires. It was no immunity at all in the face of legislation.

Id. at 900-01. Chafee complained that Meiklejohn showed "no realization of the long uphill fight which Holmes had to wage in order to give free speech its present protection." Id. at 901. In these comments, Chafee was defending himself as well as Holmes.

${ }^{\circ 05}$ Prude observes that "clear and present danger," despite Chafee's reservations about its value, had the "crucial advantage" of acceptance by a unanimous Supreme Court in Schenck. "For this reason, if for no other, Chafee was content to make the test the core of his legal position on free speech . . . ." Prude, supra note 483, at 641. Gunther accepts the plausibility of this "pragmatic ground," but he also suggests that Chafee "may not have fully appreciated the differences" between Hand and Holmes, and may have also become "an unwitting captive of the Holmes mythology he had created." Gunther did not explore these possibilities further because he focused on "Hand's thinking" rather than on Chafee's "perceptions and motivations." Gunther, supra note 14, at 747-48. 
eight months after Schenck, Frohwerk, and Debs and five months after Chafee's article in the Harvard Law Review, Holmes had accepted as his own the "manna" into which Chafee had converted this phrase. Brandeis relied even more explicitly on Chafee's interpretation of "clear and present danger" in the first amendment opinions he began to write in 1920.

\section{Justice Holmes and the Early Development of the Modern First Amendment Tradition}

Soon after writing the opinions for a unanimous Supreme Court in the first group of Espionage Act decisions, Holmes and Brandeis, relying heavily on Chafee, parted company with the Court majority in first amendment cases. Holmes's dissent in Abrams v. United States, ${ }^{608}$ which was joined by Brandeis, marks the turning point in the Supreme Court's treatment of the first amendment. This dissent, for the first time in the history of Supreme Court adjudication of free speech issues, added meaningful technical and theoretical content to first amendment guarantees. By November 1919, the date of the Abrams decision, Holmes and Brandeis had joined the ranks of the postwar civil libertarians and had begun to express their new values in constitutional terms. Holmes continued to support these values throughout the 1920's, but he often seemed ambivalent about them and occasionally exhibited vestiges of his earlier, less sympathetic attitudes. Brandeis, on the other hand, enthusiastically promoted and expanded the libertarian innovations introduced by Holmes in Abrams. In his opinions from Schaefer v. United States ${ }^{607}$ in 1920 through Whitney v. California ${ }^{608}$ in 1927, Brandeis developed a first amendment jurisprudence that laid the groundwork for the current Supreme Court position, announced in Brandenburg v. Ohio ${ }^{609}$ in 1969.

\section{A. The Majority Decisions from Abrams through Whitney}

The majority of the Supreme Court remained true to the restrictive tradition that spanned World War I. While Holmes and Brandeis broke dramatically with precedent, including their own decisions in Schenck, Sugarman, Frohwerk, and Debs, the major- 
ity applied the restrictive prewar analysis in every major first amendment case during the next decade: Abrams $v$. United States, ${ }^{\mathbf{6 1 0}}$ Schaefer $v$. United States, ${ }^{\mathbf{6 1 1}}$ Pierce v. United States, ${ }^{\mathbf{6 1 2}}$ Gilbert $v$. Minnesota, ${ }^{\mathbf{6 1 3}}$ United States ex rel. Milwaukee Social Democratic Publishing Co. v. Burleson, ${ }^{614}$ Gitlow v. New York, ${ }^{615}$ and Whitney $v$. California. ${ }^{618}$ These cases were generally prosecuted under the Espionage Act or an analogous state statute. Gitlow and Whitney punished radicals for violating state statutes that prohibited criminal advocacy or criminal syndicalism. The seven majority opinions, although citing prewar precedents with some frequency, ${ }^{617}$ relied particularly on Schenck, Frohwerk, and Debs, the most recent, and certainly in the Espionage Act prosecutions, the most relevant precedents. None of the later decisions referred explicitly to "clear and present danger."618

The majority opinion in Abrams was entirely consistent with Holmes's decisions in Schenck, Frohwerk, and Debs earlier that year. ${ }^{619}$ Holmes in Debs concluded that Schenck had "disposed of" all first amendment issues, ${ }^{620}$ and Justice Clarke, writing for the majority in Abrams, held that objections to the constitutionality of the Espionage Act were "definitely negatived" by Schenck and Frohwerk. ${ }^{621}$ Consistent with Goldman ${ }^{622}$ and with Holmes's prior decisions, Clarke treated Abrams as presenting only evidentiary questions; he found that there was "some evidence, competent and substantial, before the jury, fairly tending to sustain the verdict."'623

The defendants in Abrams were Russian immigrants who had published and distributed leaflets in English and Yiddish. These leaflets castigated President Wilson for sending American troops

${ }^{810} 250$ U.S. 616 (1919).

${ }^{812} 251$ U.S. 466 (1920).

612252 U.S. 239 (1920).

${ }^{613} 254$ U.S. 325 (1920).

614255 U.S. 407 (1921).

${ }^{610} 268$ U.S. 652 (1925).

616274 U.S. 357 (1927) (overruled in Brandenburg v. Ohio, 395 U.S. 444 (1969)).

117 See Rabban, supra note 4, at 591 n.430.

e18 Indeed, some of these later majority decisions seem consciously to paraphrase Holmes's language in Schenck to avoid using the words "clear and present danger." See Pierce, 252 U.S. at 250; Gitlow, 268 U.S. at 669.

${ }^{618}$ Others have pointed out this consistency. See Gunther, supra note 14, at 742; Ragan, supra note 14 , at $43-44$.

¿20 United States v. Debs, 249 U.S. 211, 215 (1919).

${ }^{622} 250$ U.S. at 619.

${ }^{623}$ Goldman v. United States, 245 U.S. 474 (1918).

613250 U.S. at 619 ; see also id. at 624 . 
into Russia after the Bolshevik Revolution and urged a general strike in protest. The defendants had been charged and convicted under the 1918 amendments to the Espionage Act for conspiring and attempting to harm the prosecution of the war. Justice Clarke conceded that the "primary purpose and intent" fendant alien anarchists" the Russian Revolution," ${ }^{626}$ an activity not proscribed by any law. Yet just as Holmes held that Debs's "general program" could not protect his speech if even an "incidental" and "indirect" part tended to encourage the obstruction of recruitment, ${ }^{627}$ Clarke determined that Abrams could be punished for the "obvious effect" of his language-"defeat of the war program of the United States." to obstruct the recruiting service [is evidence that the defendant] meant that they should have that effect." ${ }^{628}$ According to Clarke, "[m]en must be held to have intended, and to be accountable for, the effects which their acts were likely to produce."

The other majority opinions in the 1920's reiterated these familiar themes. Interlacing legal analysis with emotional outbursts, the opinions used the "bad tendency" doctrine as the means to punish radicals who had made a "travesty" ment by invoking its provisions "to justify the activities of anarchy or of the enemies of the United States."

\section{B. Holmes's Dissent in Abrams: The Constitutional Divide}

Holmes's dissent in Abrams broke from this continuing restrictive tradition. His landmark opinion relied on statutory and constitutional construction as well as discussions of policy at the highest levels of generality. Yet Holmes stressed, "I never have seen any reason to doubt that the questions of law that alone were before this Court in the cases of Schenck, Frohwerk, and Debs . . . were rightly decided," $"$ ass a position he reiterated in his private correspondence. Abrams, he wrote several friends, provided the occa-

\footnotetext{
624 Id. at 621.

${ }^{625}$ Id. at 623 .

${ }^{628}$ Id. at 621 .

${ }^{627} 249$ U.S. at 214-15.

628250 U.S. at 621.

620 249 U.S. at 216.

sso 250 U.S. at 621.

ss1 254 U.S. at 333.

6s2 251 U.S. at 477.

css 250 U.S. at 627 (Holmes, J., dissenting).
} 
sion for him to state the limits of the doctrine he had already set forth in his first Espionage Act decisions. ${ }^{634}$

Holmes's actual language in Abrams belies these claims. In fact, his dissent in Abrams met many of the criticisms of his earlier decisions by Hand, Freund, and especially Chafee. ${ }^{635}$ After concluding that the government had failed to prove that the defendants in Abrams had the requisite intent to hinder the prosecution of the war, Holmes acknowledged "that the word intent as vaguely used in ordinary legal discussion means no more than knowledge at the time of the act that the consequences said to be intended will ensue." ${ }^{\text {Bs8 }}$ An even weaker definition of intent, he added, forms the basis for civil and criminal liability at common law. A man could be punished "if at the time of his act he knew facts from which common experience showed that the consequences would follow, whether he individually could foresee them or not." ${ }^{337}$ Holmes himself had used these ordinary and vague conceptions of intent, which he had already analyzed in The Common Law and applied in his earlier decisions on the general law of attempts, to justify his deference to the jury determinations of guilt in Schenck, Frohwerk, and Debs. ${ }^{638}$ Yet in Abrams, Holmes maintained that the word "intent" in the amended statute must be construed "in a strict and accurate sense." Any other interpretation, he insisted, would be "absurd." "a deed is not done with intent to produce a consequence unless that consequence is the aim of the deed." Even when the probable result is obvious, intent can be ascribed to a specific act, including speech, only when the attempt to achieve a potential consequence is the "proximate motive" for the performance of that act. ${ }^{\text {g40 }}$

This new definition signaled Holmes's rejection of indirect intent, the doctrine which had formed the basis for his decisions in Schenck, Frohwerk, and Debs as well as for the majority's opinion in Abrams. Holmes now called "absurd" the analysis he himself had used previously. "To say that two phrases taken literally

osc Letter from Oliver Wendell Holmes, Jr., to Sir Frederick Pollock (Dec. 14, 1919), reprinted in 2 Holmes-PoLlock LeTTERs, supra note 449, at 32; letter from Oliver Wendell Holmes, Jr., to Mrs. John Chipman Gray (Dec. 10, 1919) (Holmes Papers, supra note 442, Box 36, Folder 5); letter from Oliver Wendell Holmes, Jr., to Albert J. Beveridge (Dec. 8, 1919) (Holmes Papers, supra note 442, Box 36, Folder 5).

${ }^{63 s}$ See supra sections V.E and VI.

${ }_{336} 250$ U.S. at 626.

${ }^{637}$ Id. at 626-27.

${ }^{638}$ See supra section IV.B (discussing Schenck, Frohwerk, and Debs).

ss9 250 U.S. at 627.

${ }^{\circ}$ Id. 
might import a suggestion of conduct that would have interference with the war as an indirect and probably undesired effect," Holmes concluded in Abrams, "seems to me by no means enough to show an attempt to produce that effect."641 Application of this reasoning might have precluded the convictions of Frohwerk and Debs.

Holmes also used his dissent in Abrams to restate the "clear and present danger" standard in language that conformed to Chafee's misconstruction of its original meaning in Schenck and that paralleled Holmes's own redefinition of intent:

I do not doubt . . . that by the same reasoning that would justify punishing persuasion to murder, the United States constitutionally may punish speech that produces or is intended to produce a clear and imminent danger that it will bring about forthwith certain substantive evils that the United States constitutionally may seek to prevent. The power undoubtedly is greater in time of war than in time of peace because war opens dangers that do not exist at other times.

But as against dangers peculiar to war, as against others, the principle of the right to free speech is always the same. It is only the present danger of immediate evil or an intent to bring it about that warrants Congress in setting a limit to the expression of opinion where private rights are not concerned. Congress certainly cannot forbid all effort to change the mind of the country. ${ }^{642}$

And Holmes added in the concluding paragraph of his opinion:

I think that we should be eternally vigilant against attempts to check the expression of opinions that we loathe and believe to be fraught with death, unless they so imminently threaten immediate interference with the lawful and pressing purposes of the law that an immediate check is required to save the country ... . Only the emergency that makes it immediately dangerous to leave the correction of evil counsels to time warrants making any exception to the sweeping command, "Congress shall make no law ... abridging the freedom of speech."643

In Abrams, as in Schenck, Holmes still viewed speech as a cat- 
egory of attempt and continued to rely on his thinking about the general law of criminal attempts. The circumstances in which speech is uttered, including the proximity and seriousness of the threatened danger as well as the intent of the speaker, remained important. But in Abrams, Holmes infused into his restatement of "clear and present danger" new elements that afforded greater protection for speech. Most strikingly, he now maintained that the proximity of the danger from speech must be "clear and imminent," not just "clear and present." He used variations of "immediate" and "imminent" with remarkable frequency throughout his dissent, and even appended "forthwith" and "pressing" for additional emphasis. ${ }^{644}$

Subtle variations in language in Abrams also indicated that Holmes was less willing than in Schenck to defer to legislative judgments of what constitutes the "substantive evils" that justify the punishment of speech threatening their occurrence. In Schenck, Holmes referred to "the substantive evils that Congress has a right to prevent" ${ }^{\text {"645 }}$ without anywhere indicating the limits of this congressional power. In Abrams, by contrast, Holmes rephrased this passage in words which significantly modify its meaning: "certain substantive evils that the United States constitutionally may seek to prevent." "646 By adding the word "certain," Holmes allowed that even some admittedly substantive evils cannot be invoked to restrict freedom of expression. And Holmes may have included "constitutionally," modifying "seek," in order to stress that the Constitution limits the government's right to prevent evil. By substituting "the United States" for "Congress," moreover, Holmes suggested that these constitutional limitations apply to all branches of government, thereby insinuating a justification for judicial review of congressional legislation without announcing a new standard that would have seemed inconsistent with the great deference manifested by his prewar and Espionage Act decisions. He now stressed that "Congress certainly cannot for-

644 Staughton Lynd has persuaded me that the word "imminent" is not inherently more protective than the word "present." If Holmes had used the phrase "clear and imminent danger" in Schenck and had substituted "clear and present danger" in Abrams, Abrams would still strike readers as the more protective decision and the word "present" would seem to convey more immediacy than the word "imminent." But the development of Holmes's views on free speech between Schenck and Abrams convinces me that Holmes intended his new formulation of "clear and imminent danger" in Abrams to be more protective than the "clear and present danger" language in Schenck. The fact that Holmes appended additional words of immediacy in Abrams reinforces my interpretation.

645 249 U.S. at 52.

368 250 U.S. at 627 (emphasis added). 
bid all effort to change the mind of the country," "and, for the first time, referred to the first amendment as a "sweeping command." jority could legitimately exercise whatever power it deemed efficient to obtain desired results.

In addition to incorporating immediacy as part of the "clear and present danger" test and to providing more support for judicial review of the constitutional limitations on legislative action, Holmes appeared to identify in Abrams the distinction between "public" and "private" speech stressed by prewar scholarly commentary on the first amendment. ${ }^{.49}$ In restating this test, Holmes implied that "where private rights are not concerned," Congress has less power to punish speech, a point he neglected to make in Schenck, Frohwerk, or Debs. Holmes seems finally to have accepted that speech on matters of public affairs deserves added protection and cannot be viewed in the same manner as a simple solicitation to do a private wrong. And he now rejected as historically inaccurate the government's claim that the first amendment did not abolish the common-law crime of seditious libel, ${ }^{851}$ a claim he had ignored the previous March. ${ }^{652}$

Holmes's concluding paragraph in his Abrams dissent, which contains the most eloquent and best remembered passages in this famous opinion, suggests that he himself recognized the vast change in his views on free speech during the eight months since he wrote Schenck, Frohwerk, and Debs:

Persecution for the expression of opinions seems to me perfectly logical. If you have no doubt of your premises or your power and want a certain result with all your heart you naturally express your wishes in law and sweep away all opposition. To allow opposition by speech seems to indicate that you think the speech impotent, as when a man says that he has squared the circle, or that you do not care whole-heartedly for the result, or that you doubt either your power or your premises. But when men have realized that time has upset many fighting faiths, they may come to believe even more than they

css See Rabban, supra note 4, at 564-66.

cso 250 U.S. at 628.

osi Id. at 630 .

${ }^{63}$ See supra notes 259-60 and 293-97 and accompanying text (briefs in Debs arguing whether first amendment prohibits punishing common-law seditious libel). 
believe the very foundations of their own conduct that the ultimate good desired is better reached by free trade in ideas-that the best test of truth is the power of the thought to get itself accepted in the competition of the market, and that truth is the only ground upon which their wishes safely can be carried out. That at any rate is the theory of our Constitution. It is an experiment, as all life is an experiment. Every year if not every day we have to wager our salvation upon some prophecy based upon imperfect knowledge. ${ }^{653}$

It is remarkable that this paragraph, which includes a stirring defense of free speech, opens with a sentence that declares, "Persecution for the expression of opinions seems to me perfectly logical." The "but" which introduces Holmes's libertarian language comes only in the fourth sentence. The second and third sentences, moreover, bear a remarkable similarity to the contents of Holmes's letters to Hand and Laski defending his decisions in Schenck, Frohwerk, and Debs, and to The Common Law. ${ }^{654}$ The text beginning with the word "but," the most general and least technical portion of the entire dissent, seems as much a confession of personal conversion as a statement of constitutional law. Holmes, perhaps unselfconsciously, appears to be commenting on himself and those of his contemporaries who came to a belated appreciation of the value of free speech. More specifically, "fighting faith" may well refer to the American support of World War I, a faith which was "upset" in the aftermath of the war when many, including Holmes's good friends at The New Republic, ${ }^{805}$ began to doubt "the very foundations of their own conduct." Only with the disillusionment that followed the war did these men begin to believe, above all, "that the ultimate good desired is better reached by free trade in ideas." Holmes here acknowledged that "the best test of truth" is not "the majority vote of that nation that can lick all others," the competition of the market."

Holmes's redefinition in Abrams of the central terms of his prior first amendment jurisprudence reflected a corresponding readjustment in his personal ideology. Yet Holmes, despite these important libertarian innovations, retained significant vestiges of his lifelong beliefs. He reapplied rather than abandoned his Social

${ }^{633} 250$ U.S. at 630.

${ }^{654}$ See supra section V.

${ }^{655}$ See supra note 38 and text accompanying notes 38-40.

${ }^{658}$ Letter from Holmes to Hand, supra note 443. 
Darwinism. He tested truth by the "power" of thought to prevail in the "competition of the market" of ideas, and did not specify the value of free speech to the individual or to society. Nor did he conceive of the first amendment as the legal expression of democratic political theory. ${ }^{657} \mathrm{He}$ still believed in the survival of the fittest, but he was now willing to let ideas battle each other rather than brute force. Holmes's dissent in Abrams did not constitute a complete transformation of his prior thought. ${ }^{658}$ But in contrast to his admittedly summary treatment of the first amendment in the first Espionage Act cases, ${ }^{659}$ Holmes strove in Abrams to develop meaningful protection for free speech. He even concluded his dissent, in an uncharacteristic display of modesty, by stating, "I regret that I cannot put into more impressive words my belief that in their conviction upon this indictment the defendants were deprived of their rights under the Constitution of the United States."

\section{Explanations for Holmes's Transformation in Abrams}

What led Justice Holmes to change his views on free speech so dramatically between his opinions for a unanimous Supreme Court in Schenck, Frohwerk, and Debs and his dissent in Abrams just eight months later? This question is difficult to answer with precision, largely because there were so many factors that might have influenced him. Certain factual differences between Abrams and the first Espionage Act cases might have prompted Holmes to write his dissent. Current events during those eight months might have alerted Holmes, as they alerted many others, to the importance of freedom of expression. And the criticisms of his earlier

es7 See A. MaIKLEJOHN, supra note 14, at 70-77.

68 Holmes had, in fact, always recognized that for the fittest to survive all competitors must be given a reasonable chance of success. In his earliest writing, he maintained that the exercise of power should be tempered by sensitivity to the shifting equilibrium among social forces. See M. Howe, supra note 370, at 46-47. This view led him to dissent from an 1896 Massachusetts decision granting an injunction against picketing. Holmes did not base his opinion on the abstract value of free expression, but on the determination that picketing was essential "if the battle" between capital and labor "is to be carried on in a fair and equal way." Vegelahn v. Guntner, 167 Mass. 92, 108, 44 N.E. 1077, 1081 (1896) (Holmes, J., dissenting). Holmes also seemed to acknowledge, in The Common Law and in private correspondence, that judges must sometimes determine the majority will by evaluating longrange rather than immediate desires. $M$. Howe, supra, at 174-75. And in The Common Law he briefly identified the public interest in the dissemination of information. $0 . W$. HoLmEs, supra note 16 , at $137,139$.

oss See supra text accompanying note 457.

250 U.S. at 631. 
Espionage Act decisions, particularly from men as prominent and respected as Chafee, Freund, and Hand, could have affected his thinking in Abrams, even in ways which Holmes himself might not have recognized.

As Holmes pointed out in his dissent in Abrams, the indictment under which the defendants were convicted alleged that they intended their publications to encourage resistance to American participation in World War I. Holmes maintained, after reviewing the texts of the defendants' leaflets, that their only object was "to help Russia and stop American intervention there against the popular government-not to impede the United States in the war that it was carrying on." "661 "An intent to prevent interference with the revolution in Russia," Holmes remarked, "might have been satisfied without any hindrance to carrying on the war in which we were engaged." soning to oppose the prosecution in Abrams, even while justifying the government's position in Schenck and Debs, ${ }^{863}$ provides further evidence that the absence of a state of war with Russia was an actual basis, and not just a rationalization, for Holmes's dissent in Abrams.

More generally, the opposition to the war expressed by the defendants in Schenck, Frohwerk, and Debs might have seemed much more threatening to Holmes than the objections by the defendants in Abrams to American interference in the Russian Revolution. Holmes characterized the facts of Abrams as involving "the surreptitious publishing of a silly leaflet by an unknown man"684 and later described the pamphlets as "poor and puny anonymities." can suppose" that this publication "would present any immediate danger that its opinions would hinder the success of the government arms or have any appreciable tendency to do so." ${ }^{\text {"668 }}$ Schenck, by contrast, was an important official of the Socialist Party, and

ser Id. at 629.

662 Id. at 628. Holmes elaborated on this reasoning for Pollock several weeks later:

[E]ven if there were evidence of a conspiracy to obstruct, etc., the overt act laid must be an act done to effect the object of the conspiracy and it seems to me plain that the only object of the leaflets was to hinder our interference with Russia. I ought to have developed this in the opinion. But that is ancient history now.

Letter from Oliver Wendell Holmes, Jr., to Sir Frederick Pollock (Dec. 14, 1919), reprinted in 2 Holmes-Pollock LeTters, supra note 449, at 32.

sos Letter from Bettman to Chafee, supra note 539.

Bes 250 U.S. at 628.

ces Id. at 629 .

Id. at 628. 
Debs was the most famous socialist in the United States. Though Frohwerk, like Abrams, was an unknown, Holmes, like much of the legal community, viewed Schenck, Frohwerk, and Debs as an interconnected trilogy, which probably made it difficult for him to consider Frohwerk on its own facts. Abrams, the only Espionage Act case decided the following fall, provided a better context than Frohwerk for Holmes to recognize and point out that less risk existed than in Schenck or Debs. It is also possible that Holmes, writing in dissent, felt able to express his personal opinions on freedom of expression more freely than when he wrote on behalf of all the Justices, many of whom had more restrictive views on the subject. ${ }^{67}$

Contemporary developments, many of which collectively formed part of the "Red Scare" of 1919-1920, might also have made Holmes more sensitive to the value of free speech by November 1919 than he had been the previous March. The national debate over the Versailles Peace Treaty, which reached its peak in the summer and early fall of 1919, convinced many, perhaps including Holmes, that their enthusiasm for the war had been misplaced. ${ }^{688}$ Retrospective doubts about the wisdom of the war might have made the opposition voiced earlier by defendants in Espionage Act cases seem less threatening to the national interest. At the same time, the popular mood of repression that contributed to the convictions of the Espionage Act defendants had culminated in the hysteria of the "Red Scare" in the months between Schenck and Abrams. The creation of the Communist Third International in March 1919, designed to encourage worldwide proletarian revolutions, intensified the preexisting domestic fear of radicals and greatly assisted the efforts of American business interests and patriotic societies to identify postwar labor conflicts with communist activity. ${ }^{669}$ Widespread industrial unrest, which began in January 1919 with a general strike in Seattle, culminated in the Boston Police Strike in September, the nationwide steel strike, also in September, and the nationwide coal strike in November. The violence that accompanied these strikes was exaggerated and sensationally reported by the national news media. The strikes and the publicity

${ }^{667}$ Chafee wrote Meiklejohn that Holmes's dissent in Abrams "is plainly an expression of personal faith such as he could not make when he was speaking for other men as well as for himself in the Schenck case." See letter from Chafee to Meiklejohn, supra note 597.

ses See W. LEUChTENBURG, supra note 32, at 50-65.

ses See id. at 67; R. MurRAY, supra note 34, at 15-18, 92-94, 121-22. 
they generated further identified labor with radicalism. ${ }^{670} \mathrm{~A}$ series of unsuccessful attempted bombings around May Day, 1919, an apparently coordinated effort directed at a variety of prominent Americans, including Justice Holmes, and explosions within an hour of each other in eight different cities about a month later, also encouraged popular alarm about radicals. ${ }^{671}$ By the fall of 1919 , virtually anyone who did not succumb to the prevailing hysteria ran the risk of being labeled a radical. ${ }^{672}$ It was during this period, for example, that Frankfurter and Chafee were under pressure to resign from the Harvard Law School. ${ }^{673}$

The excesses of the postwar hysteria produced a libertarian counterreaction. Many who had been unconcerned with civil liberties now recognized their importance. For example, as the "Red Scare" grew in 1919, The New Republic increasingly emphasized the value of free speech. ${ }^{674}$ By the end of the year, Roger Baldwin, after more than two years of failure, finally was able to convince significant numbers of nonpacifist liberals to join the civil liberties movement and form the ACLU. ${ }^{675}$ Even Alfred Bettman, while he defended his briefs for the government in Schenck and Debs, concluded his letter to Chafee in September 1919 by complimenting him on his defense of free speech during the postwar repression. ${ }^{678}$

It seems likely that the events which made many of his friends and contemporaries more sensitive to the value of free speech affected Justice Holmes as well. ${ }^{677}$ His letters rarely referred to the hysteria, perhaps because he considered it unworthy of his interest. But when Holmes heard that Frankfurter's position at Harvard might be in jeopardy because influential people considered him too radical, he promptly wrote President Lowell praising Frankfurter

670 See R. MURRAY, supra note 34, at 122; see also W. LEUChTENBURg, supra note 32, at 73-76; P. MURPHY, supra note 31, at 69-76. See generally R. MuRRAY, supra note 34, at 12265.

e71 See W. LeUchtendurg, supra note 32, at 71-72; P. MURPHY, supra note 31, at 65; R. MurRaY, supra note 34, at 68-81.

${ }^{672}$ See R. Murray, supra note 34, at 166-67.

${ }^{673}$ See A. Sutrerland, supra note 486, at 250-58; Irons, supra note 486, at 1206; Lash, supra note 39, in F. FrankFurTer, supra note 39, at 29.

674 See supra note 38 and accompanying text and sources cited therein.

675 See supra text accompanying note 40.

${ }^{676}$ Letter from Bettman to Chafee, supra note 536.

677 Edmund Wilson surmises that Holmes, long lonely for intellectual companionship, found it through his friendship with the postwar liberals. These liberals "stimulated and entertained him as well as gave him the admiration he craved." E. Wuson, supra note 370, at 775. Wilson believes that their influence may have "counted for something with Holmes in his opinions after the first World War in cases in which the issue of free speech was involved." Id. at 772. 
for contributing to "the ferment which is more valuable than an endowment." later maintained that this "period of hysteria undoubtedly focused the attention of Mr. Justice Holmes on the practical consequences of a relaxed attitude toward" free speech. ${ }^{679}$

It also seems probable that the reactions to his earlier Espionage Act decisions by Chafee, Freund, and Hand contributed to the more libertarian approach Holmes took in Abrams. The impact of Chafee on Holmes is easiest to trace. Harold Laski, who was well acquainted with both Chafee and Holmes, invited both men to tea in late July 1919, midway between Schenck and Abrams. Laski, who had given Holmes a copy of Freedom of Speech in War Time before this meeting, wrote Chafee that "we must fight on it." Unfortunately, no record of this meeting appears to exist. But Chafee, in a letter to Judge Amidon the following September, commented on his summer conversation with Holmes. Chafee came away from this encounter with the impression that he did not convince Holmes about several key points in his article. Although Chafee was certain that Holmes, as a juror, would have voted to acquit Debs, Chafee reported that Holmes "is inclined to allow a very wide latitude to Congressional discretion in the carrying on of the war" and "further thinks that he could not have gone behind the jury verdict in the Debs case." Chafee applied to Holmes the criticism he had expressed in his article against federal district and circuit court judges. He called Holmes a "failure" for his "omission to state the principles" by which to judge free speech claims. ${ }^{681}$

Holmes, though apparently not converted by his initial reading of Freedom of Speech in War Time or by his summer meeting with Chafee, soon began to agree with him. ${ }^{682}$ Holmes's dissent in

623 Letter from Oliver Wendell Holmes, Jr., to A. Lawrence Lowell (June 2, 1919), reprinted in 1 HoLmes-LASKI LETTERS, supra note 442, at 211 n.2. A letter from Holmes to Frankfurter took a different tack. Holmes, after assuring Frankfurter that "I believe in academic freedom," quickly added that "a professor's conduct may affect the good will of the institution to which he belongs." A professor would not be doing "his whole duty if he merely indulged his spontaneity-even in a case where he had opinions that required courage to state and that he thought it desirable to make known. He must weigh this harm that he may do to his employer while he takes his employer's pay." Letter from Oliver Wendell Holmes, Jr., to Felix Frankfurter (Dec. 4, 1919) (Holmes Papers, supra note 442, Box 36, Folder 5).

679 F. Frankpurter, Mr. Justice Holmes and the Supreme Court 79 (2d ed. 1961).

4 so Letter from Harold Laski to Zechariah Chafee, Jr. (July 23, 1919) (Chafee Papers, supra note 189, Box 14, Folder 15).

os1 Letter from Chafee to Amidon, supra note 459.

682 Evidently, Holmes did not correspond about his meeting with Chafee and Laski until 1920. After receiving a copy of Chafee's book, Freedom of Speech, Holmes wrote Laski 
Abrams, written less than four months after this talk, provides the best evidence of Chafee's influence. Most strikingly, after omitting any reference to "clear and present danger" in Frohwerk and Debs, Holmes reformulated this phrase in Abrams in a way which indicated that he now interpreted these words more as Chafee had misconstrued and glorified them than as he himself had originally used them in Schenck.

The Abrams dissent incorporated other views of the first amendment advocated by Chafee, Hand, and Freund, but missing from Holmes's own prior decisions. Holmes emphasized in Abrams the relationship between free speech and the search for truth, recognized its importance even during a war, and conceded that the first amendment is inconsistent with the common law of seditious libel. Although Holmes required "specific intent" in Debs as well as Abrams, his stress in Abrams on a "strict" construction of intent responded to the concerns of Chafee, Hand and Freund about employing vague standards to evaluate the legality of speech. Perhaps most importantly, Holmes accepted in Abrams the independent judicial role they all had advocated. For the first time, Holmes indicated that he had abandoned his reflexive deference to legislative or jury determinations affecting the exercise of free speech. No longer treating the Espionage Act cases as "routine criminal appeals," ${ }^{883}$ he now seemed to appreciate their constitutional dimension.

It is impossible to determine which of these plausible influences actually account for the libertarian innovations Holmes introduced in his Abrams dissent. Holmes himself did not help solve this puzzle. He never directly acknowledged that he had altered his interpretation of the first amendment between his initial Espionage Act decisions and Abrams. In fact, many of his statements indicate that he considered his dissent in Abrams a logical extension of Schenck, Frohwerk, and Debs. The language of the dissent, however, contradicts Holmes's claims to consistency. All or some of these factors, consciously or unconsciously, might have helped change his views. Though the reasons remain uncertain, the signifi-

that "the preliminary extracts in [the] Harvard Law Review" were "first rate." Letter from Oliver Wendell Holmes, Jr., to Harold Laski (Dec. 17, 1920), reprinted in 1 HoLMES-LASkr LETTERS, supra note 442, at 297. In a letter earlier that yesr to Sir Frederick Pollock, Holmes mentioned that Chafee "is said to be a very good man" and, referring to his talk with Chafee the previous summer, described him as "unusually pleasant and intelligent." Letter from Oliver Wendell Holmes, Jr., to Sir Frederick Pollock (June 21, 1920), reprinted in 2 Holmes-Pollock LETTERS, supra note 449, at 45.

${ }^{683}$ Kalven, supra note 14, at 238. 
cant transformation in Holmes's approach to freedom of expression is evident.

\section{Holmes After Abrams}

Holmes's dissent in Abrams, written against an unacknowledged tradition of judicial hostility to the value of free speech, constituted the first significant libertarian construction of the first amendment in the history of the United States Supreme Court. For the next decade, Holmes and Brandeis dissented in almost every first amendment case. After Abrams, the leadership passed to Brandeis, who wrote most of the dissenting opinions and made the major doctrinal advances. Holmes did not retreat from the views he expressed in Abrams and generally went along with Brandeis, but Holmes's limited writing on the first amendment after Abrams demonstrates that he never entirely escaped from the attitudes revealed in his prior restrictive decisions. Nor did he ever again attain the eloquence that accompanied his conversion in Abrams.

In his dissent in Gitlow v. New York, ${ }^{684}$ Holmes repeated the immediacy requirement he imported into the "clear and present danger" test in Abrams. The publications at issue in Gitlow, Holmes reasoned, referred to "some indefinite time in the future" and did not constitute "an attempt to induce an uprising against government at once." He warned against punishing speech at a point "too remote from possible consequences," and he concluded that "no present danger" existed. ${ }^{685}$ After quoting his statement of "clear and present danger" in Schenck as "the criterion sanctioned by the full Court," ${ }^{\circ 86}$ he maintained, consistently with the argument of Chafee's scholarly writings, that the majority in Abrams had "departed from" Abrams and Schaefer as having "settled the law" because the "convictions" he expressed in his Abrams dissent "are too deep." He closed his dissent in Gitlow by protesting that "the indictment alleges ... publication and nothing more," raised by Stedman and ignored by the entire Court in Sugarman

268 U.S. at 652 (1925).

as Id. at 673 (Holmes, J., dissenting).

ss Id. at 672 .

687 Id. at 673.

688 Id.

689 Id. 
and Debs. ${ }^{690}$

In other cases after Abrams, Holmes dissented on first amendment grounds. Despite decades of precedent to the contrary, ${ }^{601}$ including many cases in which he had concurred, Holmes maintained in Leach v. Carlile ${ }^{692}$ that the Postmaster General had violated the first amendment by prohibiting the delivery of mail to a company advertising its "Organo Tablets" as a general cure. "If the execution of this law does not abridge freedom of speech," Holmes concluded, "I do not quite see what could be said to do so." United States $v$. Schwimmer, ${ }^{684}$ Holmes dissented from the majority's decision to deny a pacifist's petition for naturalization. Although the petitioner "found the United States nearest her ideals of a democratic republic" and "expressed steadfast opposition to any undemocratic form of government," that her pacifism made her ineligible for citizenship. "The fact that she is an uncompromising pacifist with no sense of nationalism but only a cosmic sense of belonging to the human family," Justice Butler wrote for the majority, "justifies belief that she may be opposed to the use of military forces as contemplated by our Constitution and laws." ${ }^{698}$ Because a person holding such views would be "disposed" to encourage the harmful and sometimes unlawful activites engaged in during World War I by "those who described themselves as pacifists and conscientious objectors," 697 the majority determined that it "was bound by the law to deny her application." ${ }^{888}$ Holmes disagreed. He acknowledged that the petitioner's views "might excite popular prejudice, but if there is any principle of the Constitution that more imperatively calls for attachment than any other it is the principle of free thought-not free thought for those who agree with us but freedom for the thought that we hate." 698

Despite his adherence to the libertarian views he first set forth in Abrams, Holmes lagged behind Brandeis throughout the 1920's. In Gilbert v. Minnesota, ${ }^{700}$ Brandeis, in a forceful dissent, main-

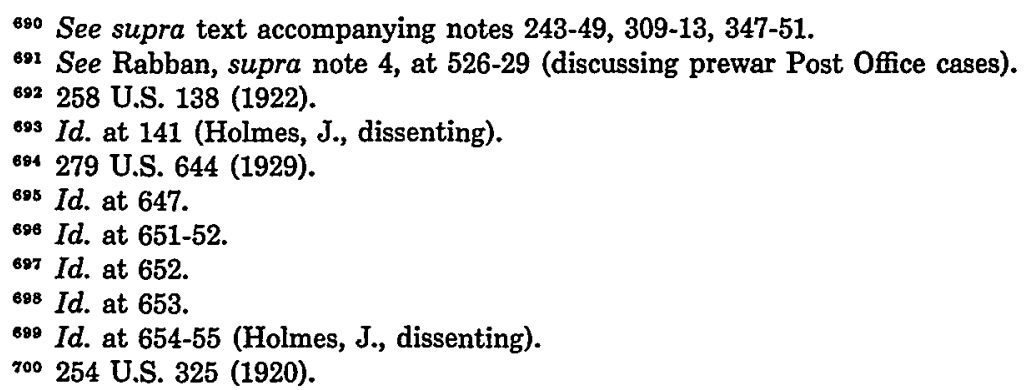


tained that federal constitutional law invalidated a state sedition statute. $^{701}$ When Brandeis sent Holmes the draft of his dissent, Holmes replied on its cover: "I think you go too far." Holmes wrote Brandeis that he would instead "concur in result on the record."

Holmes also did not go as far as Brandeis in United States ex rel. Milwaukee Social Democratic Publishing Co. v. Burleson.703 Both Holmes and Brandeis dissented from the majority's affirmance of Postmaster General Burleson's decision to revoke, under the authority of the Espionage Act, the second-class mailing privileges of the Milwaukee Leader, a socialist newspaper. Holmes began his separate, shorter, and less forceful dissent by indicating that he had initially intended to vote with the majority and had changed his mind only after reading Brandeis's dissent. ${ }^{704} \mathrm{He}$ wrote a friend two days before the publication of this decision that Brandeis's "printed argument convinced me contrary to my first impressions." "קos

Holmes's dissent in Gitlow, although it reaffirmed immediacy as a component of the "clear and present danger" test, similarly failed to express a principled commitment to libertarian values. Holmes revealed in Gitlow the extent to which Social Darwinism still dominated his views. "If in the long run the beliefs expressed in proletarian dictatorship are destined to be accepted by the dominant forces of the community," Holmes stated, "the only meaning of free speech is that they should be given their chance and have their way." relative powerlessness and his "redundant discourse." In a subsequent letter to Laski, Holmes referred to his dissent in Gitlow as "a page of slack on the right of an ass to drool about proletarian dictatorship." "708 These comments do not reflect real appreciation of the social and individual benefits of free speech.

${ }^{01}$ Id. at 334 (Brandeis, J., dissenting).

${ }^{702}$ Note from Oliver Wendell Holmes, Jr., to Louis D. Brandeis (Louis D. Brandeis Papers, Box 5, Folder 13, Harvard Law School Library) [hereinafter cited as Brandeis Papers, Harvard].

${ }^{203} 255$ U.S. 407 (1921).

${ }^{704}$ Id. at 436-37 (Holmes, J., dissenting).

${ }^{70 s}$ Letter from Oliver Wendell Holmes, Jr., to Mrs. Gray (Mar. 5, 1921) (Holmes Papers, supra note 442, Box 36, Folder 7).

${ }_{708} 268$ U.S. at 673 (Holmes, J., dissenting); see Cover, The Left, the Right, and the First Amendment, 40 MD. L. Rev. 349, 383 n.118 (1981) (Social Darwinism a source for the "notion that in minorities may reside the seed for future growth of society").

${ }^{707} 268$ U.S. at 673.

${ }^{708}$ Letter from Oliver Wendell Holmes, Jr., to Harold Laski (June 14, 1925), reprinted in 1 Holmes-Laski LeTtrers, supra note 442, at 752 (M. Howe ed. 1953). 
Holmes's short dissent in Gitlow also left unanswered a major challenge to the "clear and present danger" test raised by the majority opinion. According to the majority, this test governed only cases, such as those brought under the Espionage Act, "where the statute merely prohibits certain acts involving the danger of substantive evil, without any reference to language itself, and it is sought to apply its provisions to language used by the defendant for the purpose of bringing about the prohibited results." "709 If the legislature itself, as in Gitlow, makes the determination that "utterances of a certain kind involve such danger of substantive evil that they may be punished, the question whether any specific utterances coming within the prohibited class is likely, in and of itself, to bring about the substantive evil, is not open to consideration." T110 The test announced by Holmes in Schenck, the majority concluded, "has no application"711 to Gitlow. Brandeis's concurrence in Whitney two years later explicitly rejected this deference to legislative judgments about the danger of speech as a substantive evil, ${ }^{712}$ but Holmes's own dissent in Gitlow, while revealing his disagreement with the majority's reasoning, simply ignored this important limitation on his opinion in Schenck..$^{713}$

Finally, in Schwimmer, Holmes made a special point of calling "unfounded" any anxieties that the petitioner might follow the bad example of Schenck in a future war. "Her position and motives," Holmes asserted, "are wholly different from those of Schenck." He maintained that "Quakers have done their share to make the country what it is," and accused the majority of wanting "to expel them because they believe more than some of us do in the teachings of the Sermon on the Mount."115 Holmes's insistence that Schenck was appropriately punished suggests that his admirable defense of Quakers was not a libertarian statement of the general importance of free expression.

\section{The Contribution of Brandeis}

Justice Brandeis, much more than Justice Holmes, developed the theoretical justifications for a libertarian judicial construction

\footnotetext{
708268 U.S. at $670-71$.

730 Id. at 670.

721 Id. at 671 .

712 See infra text accompanying notes 850-52.

713 See Rogat, supra note 370 , at 217.

714279 U.S. at 654 (Holmes, J., dissenting).

${ }^{215} \mathrm{Id}$. at 655.
} 
of the free speech clause of the first amendment. In a remarkable series of opinions from 1920 through 1927, Brandeis, relying extensively on Chafee's scholarship, elaborated and expanded the libertarian innovations of Holmes's dissent in Abrams without adopting Holmes's lingering Social Darwinism. Unlike the aloof Holmes, detached from and often contemptuous of human efforts to change society, Brandeis became an activist who combined a genuine humanitarianism with a firm belief in individual dignity and autonomy. As often as Holmes was impressed by the acquisition and exercise of power in the struggle for existence, Brandeis was outraged by its abuse. Even when Holmes recognized that power exceeded its legitimate limits, he found it difficult to identify with its victims. As one of Holmes's law clerks summed up the difference between the two Justices, "Brandeis feels sympathy for the oppressed, Holmes contempt for the oppressor." 16

Brandeis wrote five major first amendment opinions in the 1920's: four dissents and one concurrence that was essentially a dissent. ${ }^{717}$ In all of these opinions, he analyzed the ideological foundations of the first amendment in significantly greater detail than did Holmes during the same period. Instead of adopting Holmes's focus in Abrams on the "free trade in ideas" and the "competition of the market" in the search for truth, Brandeis emphasized the intrinsic importance of free speech. ${ }^{718} \mathrm{He}$ stressed its value to the individual as well as to society. Above all, Brandeis considered free speech an essential prerequisite of a democracy. ${ }^{719}$

716 Lockwood, Justice Holmes-Year 1928-29, at 9 (Felix Frankfurter Papers, Box 146, Library of Congress). Lockwood did not know the source of this quotation, but had heard it attributed to a foreigner. Id. at 8 . "Whoever stated it," he added, "sensed something very deep in Holmes's character." Id. at 9.

${ }_{717}$ Whitney v. California, 274 U.S. 357, 372 (1927) (concurring); United States ex rel. Milwaukee Social Democratic Publishing Co. v. Burleson, 255 U.S. 407, 417 (1921) (dissenting); Gilbert v. Minnesota, 254 U.S. 325, 334 (1920) (dissenting); Pierce v. United States, 252 U.S. 239, 253 (1920) (dissenting); Schaefer v. United States, 251 U.S. 466, 482 (1920) (dissenting).

${ }^{718}$ See Cover, supra note 706, at 373 (listing implications of Holmes's language and suggesting contrasts with Brandeis's approach); cf. id. at 377 (comparing Holmes's view that "truth will prevail in some market place of ideas" with Brandeis's emphasis on the importance of speech to "deliberative politics"). Cover adds that Holmes "had failed to specify, save metaphorically, how the struggle of ideas was related to the production of truth or decision in the polity. The market metaphor was anti-political." Id. at 381.

710 For Cover, id. at 377, Brandeis's "chief free speech refrain" is the theme that "free input is necessary to deliberative politics." See also id. at 363 ("ultimate objective" of Holmes and Brandeis was "the order necessary to achieve the deliberative politics of popular government"); cf. id. at $380,383,385-86$. The centrality of this theme should not overshadow other important elements of Brandeis's first amendment jurisprudence. Brandeis also stressed that freedom of expression is a fundamental right of individuals, a position 
Brandeis followed Holmes in accepting "clear and present danger" as the constitutional standard for his libertarian values, but he expanded its meaning beyond even Chafee's construction and combined it with Hand's incitement test. Brandeis supported his theoretical positions with concrete examples rooted in the events that led to the Espionage Act prosecutions. In marked contrast to his decision in Sugarman, ${ }^{720}$ his opinions in the 1920's addressed and agreed with the arguments made by the defendants in the initial Espionage Act cases, particularly in the briefs by Stedman and Roe in Debs. ${ }^{721}$ Brandeis was the first Justice after the war ${ }^{722}$ to assert that the first amendment applies to the states through the fourteenth amendment. Responding, as Holmes did not, to the majority's reasoning in Gitlow, ${ }^{723}$ he also supported judicial review of legislative determinations that certain categories of speech are themselves substantive evils.

\section{A. Brandeis Before the War}

Brandeis, like most postwar civil libertarians, was essentially uninvolved with free speech issues during the prewar period. Brandeis had achieved widespread prominence as a reformer before the war, but, consistent with the thrust of the progressive movement, he focused on the economic issues which seemed so pressing in the early twentieth century rather than on civil liberties. He was a leader of the older school of progressive thought that resisted the concentration of power advocated by later progressives such as Herbert Croly and his followers at The New Republic, and translated into a political program by Theodore Roosevelt's "New Nationalism."724 The pithy titles of Brandeis's collections of essays,

that helped connect his views on politics and economics. See infra sections VIII.A (discussing Brandeis's belief that capitalism fosters the individuality necessary for economic selfsufficiency and political liberty) and VIII.D.4 (discussing "theoretical foundations" of Brandeis's views on free speech); cf. L. TRIBE, American Constitumonal Law $\$ 12-1$, at 579 (1978) (Brandeis "did not make the mistake of reducing freedom of speech to its instrumental role in the political process").

${ }^{220} 249$ U.S. 182 (1919); see supra text accompanying notes 309-13 (discussing Sugarman).

721249 U.S. 211 (1919); see supra text accompanying notes 243-69 (discussing briefs).

${ }^{222}$ Dissenting in Patterson v. Colorado ex rel. Attorney Gen., 205 U.S. 454, 463-65 (1907), Harlan maintained that the free speech and free press clauses of the first amendment apply to the states through the privileges and immunities and due process clauses of the fourteenth amendment. See infra note 853 (discussing Harlan's dissent in Patterson).

${ }^{233}$ See supra text accompanying note 709 (discussing distinction by the majority in Gitlow between legislation directed at language itself and legislation directed at acts).

724 See generally C. ForcEY, supra note 32. The phrase "New Nationalism" was borrowed from Croly's book, The Promise of American Life (1909). Learned Hand mailed this 
The Curse of Bigness ${ }^{28}$ and Other People's Money, ${ }^{726}$ convey the gist of his concerns. His activities against banks and oil trusts, his opposition to railroad mergers, and his investigations into the corruption of government officials by big business involved him in many of the major issues on the progressive agenda and brought him a national reputation as "the people's lawyer." Brandeis was also instrumental in the creation of the United States Commission on Industrial Relations, and he became an important ally and a close friend of Senator Robert M. La Follette, a visible and, for a time, powerful progressive politician. ${ }^{727}$

The same values that generated Brandeis's commitment to economic reform account for his later contributions to first amendment doctrine. Brandeis had a fundamental belief in capitalism that transcended purely economic considerations. ${ }^{728} \mathrm{He}$ believed that the free enterprise system has moral worth; that the struggle to make a living develops character by fostering individuality, self-

book to Theodore Roosevelt in the spring in 1910. C. Forcey, supra note 32, at 123. "I do not know when," Roosevelt wrote Croly the following July, "I have read a book which I felt profited me as much as your book on American life." Quoted in id. at-124-25. Although Forcey believes that most historians have overemphasized the relationship between Croly and Roosevelt, he does not dispute Croly's influence, and he acknowledges the substantial similarities between Croly's ideas and Roosevelt's political program. Id. at 127-39. M. PEterson, The Jefrerson Image in the American Mind 340-42 (1960), contains an excellent short analysis of Croly's thought.

Because Brandeis rejected the "New Nationalism," he refused to be associated with the New Republic circle. C. Forcey, supra note 32, at 207-08. Indeed, Brandeis actively supported Woodrow Wilson against Roosevelt in 1912 because he considered the "New Nationalism" a program that perpetuated the evils of monopolies by merely transferring them from private to public control. See D. AAron, MEn OR GoOd Hope 250-51, 281-82 (1951); A. Mason, Brandeis, A Free Man's Life 375-84 (1946); M. Urofsky, Louis D. Brandeis and THE Progressive Tradition 73 (1981). One eminent scholar of the progressive period, however, concludes that a shared belief "in an outer ring of rules and an inner core of administrative management" overshadowed the relatively minor differences between the WilsonBrandeis "New Freedom" and the Croly-Roosevelt "New Nationalism." R. WIBBE, supra note 31 , at 218 .

${ }^{325}$ L. Brandeis, The Curse of Bigness (1934).

726 L. Brandeis, Other People's Money (1914).

${ }^{727}$ A. Mason, supra note 724, contains a thorough discussion of Brandeis's progressive activities. J. Weinstein, The Corporate Ideal in The Liberal State: 1900-1918, at 181, 185 (1968), describes Brandeis's role in creating the United States Commission on Industrial Relations. B. LA Follette \& F. LA Follette, 1 Robert M. LA FolletTe 289-91, 586-87 (1953), reveals the close relationship between the La Follette and Brandeis families. See also 2 LeTtrRs of Louis D. Brandeis 329 n.2 (M. Urofsky \& D. Levy eds. 1972) (editors' note) [hereinafter cited as 2 BRANDEIs LETTERs].

728 Abrams, Brandeis and the Ascendancy of Corporate Capitalism, Introduction to L. Brandeis, Other People's Money (Harper Torchbook edition 1967), includes an exceptionally penetrating analysis of the moral roots of Brandeis's political and economic thought. See id. at xx, xxvi, xxxvi; see also R. Abrams, Consbrvatism in a Progressive Era 55-59 (1964). 
reliance, personal responsibility, and an appreciation of freedom essential to a democracy. ${ }^{729}$ According to Brandeis, economic and political liberty are inextricably connected; jeopardizing one threatens the other. He argued that economic self-sufficiency is a prerequisite to political freedom. Brandeis did not attack capitalism itself, only the centralization that, in the name of capitalism, endangered its soul and the democratic virtues it produced. $\mathrm{He}$ complained that the representatives of corporate capitalism were "playing the industrial game with loaded dice." ${ }^{330} \mathrm{He}$ did not want to change the game, but only to make sure that people played by the traditional fair rules. The dominance of monopolies and trusts loaded the dice against the common man and destroyed the character of both the powerful and the dependent.

Brandeis fought the "curse of bigness" produced by corporate conglomerations and glorified the individual struggles of entrepreneurs. He criticized bankers for relying on "other people's money" instead of their own efforts, not for wanting to get rich. Although Brandeis was confident that the dissolution of economic concentration would create "industrial efficiency," he placed greater emphasis on the anticipated personal and social benefits. Even more important than efficiency, he argued, are industrial and political liberty. ${ }^{731}$ These views help resolve the apparent contradiction between his successful striving for personal wealth and his later activities as an opponent of big business. Brandeis was a classic capitalist who was deeply disturbed that corporate power threatened the system of free enterprise that, in his opinion, made the United States a great nation.

Despite his essentially traditional ideology, Brandeis's almost religious commitment to individual dignity and his certainty about the connection between economic and political liberty made him much more sensitive than most of his contemporaries to the range of problems faced by people subject to the pressures of corporate capitalism. Brandeis, like most progressives, viewed the economic organization of society as the primary problem facing the country. At the same time, he was concerned about the repression of civil

729 See, e.g., letter from Louis D. Brandeis to Winthrop Talbot (April 16, 1912), reprinted in 2 BRANDEIS LETTERS, supra note 727, at 586-89; letter from Louis D. Brandeis to Charles Richard Crane (Nov. 11, 1911), reprinted in 2 BrandeIs LETTERS, supra note 727, at 510-11.

${ }^{730}$ Letter from Louis D. Brandeis to Norman Hapgood (Feb. 27, 1911), reprinted in 2 BrandeIs LeTTERS, supra note 727, at 412.

7321 Final Report and Testimony of Commission on Industrial Relations, S. Doc. No. 415, 64th Cong., 1st Sess. 1003 (1917) (testimony of Mr. Brandeis). 
liberties, including free speech, in the industrial world. Brandeis protested the treatment of I.W.W. members during a strike in Lawrence, Massachusetts. He maintained that "citizens and aliens have, under the guise of administering or enforcement of the law, been denied civil rights." "7s2 The use of police as strikebreakers, he added, created disrespect for law and encouraged violence. ${ }^{733} \mathrm{Bran}$ deis argued that the indiscriminate use of injunctions would produce unacceptable restrictions on free speech, ${ }^{734}$ and he criticized the Massachusetts courts for often straining the facts to interpret peaceful picketing as including illegal threats or intimidation. ${ }^{735}$

Though concerned about these abuses, Brandeis explicitly rejected the goals of the I.W.W. and other radical groups. He used the I.W.W. strikes as an argument in favor of establishing the United States Commission on Industrial Relations. ${ }^{736}$ He hoped that the Commission would discover the underlying causes of industrial unrest and suggest social reforms to prevent its recurrence. ${ }^{737}$ Unlike Schroeder and Roe, who concentrated on free speech issues, Brandeis emphasized the solution of industrial problems in his testimony before the Commission. ${ }^{738}$ Brandeis wanted to stop the growth of the I.W.W. by bringing its members into the mainstream of society. He was scared of the I.W.W. and cited its successes to demonstrate that "conservative trade unionism is essential to the maintenance of law and order." helped organize a National Civic Federation, which he hoped would create "some conservative substitute for radical measures," ${ }^{\prime \prime 40}$ and opposed violations of the law by the rich and the

\footnotetext{
${ }^{732}$ Letter from Louis D. Brandeis to Jocelyn Paul Yoder (Feb. 26, 1912), reprinted in 2 BRANDEIS LETTERS, supra note 727, at 563.

${ }^{233}$ Letter from Louis D. Brandeis to Charles Warren Clifford (July 11, 1912), reprinted in 2 BRANDRIS LETTERS, supra note 727, at 646-47.

${ }^{234}$ Letter from Louis D. Brandeis to Norman Hapgood (Oct. 14, 1908), reprinted in 2 BRANDEIS LetTERS, supra note 727, at 210-11.

${ }^{235}$ Letter from Louis D. Brandeis to E.R. Thayer (May 20, 1912) (Brandeis Papers, Harvard, supra note 702, Box 14, Folder 11).

${ }^{736}$ Letter from Brandeis to Yoder, supra note 732.

${ }^{237}$ Letter from Louis D. Brandeis to William Howard Taft (Dec. 30, 1911), reprinted in 2 BrANDEIS LETTERS, supra note 727, at 531-35. This letter was signed by many other prominent people. See 2 BrandeIs LeTTERS, supra note 727, at 535 n.2.

738 Compare testimony of Louis D. Brandeis (Vol. I at 991-1011; Vol. VIII at 7657-81) with testimony of Theodore Schroeder (Vol. XI at 10,840-52, 10,866-96) and testimony of Gilbert E. Roe (Vol. XI at 10,468-93), Final Report and Testimony of Commission on Industrual Relations, S. Doc. No. 415, 64th Cong., 1st Sess. (1917).

739 Letter from Brandeis to Talbot, supra note 729.

710 Letter from Louis D. Brandeis to Ralph Montgomery Easley (July 16, 1907), reprinted in 2 BRANDEIS LeTters, supra note 727, at 13. See also J. WeINSTBIN, supra note 727 , at 17.
} 
powerful because he feared that they would breed "anarchical and socialistic sentiment."741 Brandeis emphasized his opposition to socialism. The concentration of authority in the state, in his opinion, posed the same threats to the individual as private economic power. ${ }^{742}$

Like most people who later became prominent civil libertarians, Brandeis never held radical views or participated in any extensive way in defending freedom of speech before World War I. Brandeis also shared the background and status of those later converts: he had finished first in his class at Harvard Law School and had become a rich and respected corporate lawyer in Boston. By the first years of the twentieth century, however, Brandeis had turned most of his prodigious energy from his lucrative law practice, which had already made him a millionaire, to his fight against the concentration and abuse of economic power. ${ }^{743}$ Through these activities he came to understand contemporary social conditions that escaped the attention of most postwar civil libertarians until some time during or after the war.

\section{B. Brandeis and Freedom of Expression: 1918-1920}

Brandeis's background and beliefs suggested to many that he would take the lead in protecting freedom of expression as soon as he joined the Supreme Court in 1916. Letters to Brandeis throughout 1918 from a variety of people concerned with the suppression of free speech after the American entry into World War I testify to the widespread assumption that he would be sympathetic: Felix Frankfurter wrote Brandeis from Bisbee, Arizona to describe the efforts of mine owners to "monopolize patriotism" while violating the civil rights of miners during an I.W.W. strike; ${ }^{74}$ Amos Pinchot, a prominent civil libertarian, asked him to write to President Wilson or Attorney General Gregory to protest the continuing prose-

${ }^{741}$ Letter from Louis D. Brandeis to William Lawrence (May 14, 1908), reprinted in 2 BrandeIS LETTERS, supra note 727, at 152.

${ }^{742}$ For example, Brandeis disapproved of the German system of compulsory insurance as not being "in harmony with the American ideas of individual liberty." Instead, Brandeis argued, a worker should be able to earn sufficient wages to afford insurance "through his own efforts" and thereby develop "strength of character and self-control." Letter from Louis D. Brandeis to John Edward Pember (Feb. 4, 1908), reprinted in 2 Brandeis LeTters, supra note 727 , at 74 .

${ }^{743}$ A. Mason, supra note 724, at 77-106.

744 Letter from Felix Frankfurter to Louis D. Brandeis (Oct. 20, 1917) (Louis D. Brandeis Papers, Box WW 1-1, University of Louisville Archives) [hereinafter cited as Brandeis Papers, Louisville]. 
cution of the editors of The Masses and enclosed his own letter of protest to Wilson; ${ }^{745}$ the Liberty Defense Union solicited Brandeis to contribute to a defense fund to pay the legal costs of defendants charged with violating the Espionage Act and sent him literature describing the repression of free speech and free press under the authority of that law; $;^{74}$ a personal friend of the Brandeis family, stymied by "the ban on free speech," sought advice on how "radical and liberal and not necessarily pacifist groups" could organize to support a democratic settlement of the war along the lines outlined by President Wilson; ${ }^{747}$ Senator La Follette's son, Phil, wrote to "Uncle Louis" protesting accusations of disloyalty against him and fellow officers while he was serving in the Army in Oklahoma and trying to find a way to fight in France; ${ }^{78}$ Samuel Eliot Morison, a former neighbor and a lecturer in history at Harvard, asked Brandeis to request an investigation of similar charges made against him; ${ }^{79}$ and a man imprisoned for making allegedly proGerman remarks, despite having frequently attempted to register for the draft, wrote Brandeis from prison "in behalf of hundreds of more or less innocent victims of war furor and hysteria."750 Two of the few federal district court judges who tried to protect civil liberties during the war wrote to Brandeis in 1918 about the Espionage Act prosecutions: Judge Amidon sent Brandeis a copy of oral observations he had made during sentencing in an Espionage Act case, ${ }^{751}$ and Judge Anderson mailed Brandeis a copy of a letter he had written to Attorney General Gregory because he wanted to share the same thoughts with Brandeis. ${ }^{752}$ Brandeis also kept ex-

${ }^{765}$ Letter from Amos Pinchot to Louis D. Brandeis (May 24, 1918) (Brandeis Papers, Louisville, supra note 744, Box WW 3-1).

${ }^{76}$ Letter from Liberty Defense Union to "Dear Friend" (July 1, 1918) (Brandeis Papers, Louisville, supra note 744, Box WW 3-1).

${ }^{747}$ Letter from Gertrude L. Winslow to Louis D. Brandeis (Oct. 3, 1918) (Brandeis Papers, Louisville, supra note 744, Box WW 3-1).

${ }^{78}$ Letter from Phil La Follette to Louis D. Brandeis (Nov. 6, 1918) (Brandeis Papers, Louisville, supra note 744, Box WW 3-1).

749 Letter from Samuel Eliot Morison to Louis D. Brandeis (Sept. 1, 1918) (Brandeis Papers, Louisville, supra note 744, Box WW 3-1).

${ }^{730}$ Letter from William K. De Blocq to Louis D. Brandeis (Nov. 19, 1918) (Brandeis Papers, Louisville, supra note 744, Box WW 3-1h).

${ }^{781}$ Letter from Charles F. Amidon to Louis D. Brandeis (Aug. 5, 1918) (Brandeis Papers, Louisville, supra note 744, Box WW 2-1).

${ }^{732}$ Letter from George W. Anderson to Louis D. Brandeis (Dec. 7, 1918) (Brandeis Papers, Louisville, supra note 744, Box WW 5-6). "The country and a good many of the Federal Courts," Anderson observed, "have gone as crazy as the Federalistic party and the Federal Courts did after the Alien and Sedition Laws of 1798." He pleaded with Gregory "not [to] suppress free speech any more." Letter from George W. Anderson to T.W. Gregory (Dec. 7, 1918) (Brandeis Papers, Louisville, supra note 744, Box WW 5-6). Responding to 
tensive files of clippings from the trade, labor, and general press, in which he highlighted reports of free speech violations as well as the statement in defense of conscientious objection made in open court by Roger Baldwin after being sentenced to jail. ${ }^{763}$

It is unclear whether Brandeis responded to most of these letters. He did write a short letter of support to Senator La Follette in November 1918, the day after a Senate investigating committee dropped its charges against him for delivering an antiwar speech soon after the United States had entered World War I. ${ }^{754}$ Brandeis did not comment, however, on the merits of either the investigation or La Follette's defense. ${ }^{755}$ In early 1919 Brandeis rejected a request that he meet with people associated with the National Civil Liberties Bureau, the direct predecessor of the ACLU, to discuss the Espionage Act prosecutions and censorship of the press. ${ }^{758}$ But by the end of 1919 he compared contemporary events in the United States to the Spanish Inquisition and added: "The intensity of the frenzy is the most hopeful feature of this disgraceful exhibition;- - of hysterical, unintelligent fear-which is quite foreign to the generous American nature. It will pass like the Knownothing days, but the sense of shame and of sin should endure."767 In a letter to Learned Hand in January 1920, Brandeis expressed his view that "we are over the worst of the reaction, or rather, we have a counter current moving." The expulsion of elected Socialists by the New York State Assembly, he observed, "was fortunate

Gregory's fears about communism, Anderson asserted that its dangers "cannot be successfully met by adopting Junker tactics and morals," which would be more likely to produce communism than "the unaided efforts of a lot of soap-box orators." "The American citizen," Anderson added, "has a constitutional right to be a blank fool, at any rate in time of peace,- and that includes the right to show himself to be a blank fool by and through winged words." Id.

${ }^{783}$ See Brandeis Papers, Louisville, supra note 744, Box WW 7-1. While in private practice, Brandeis represented Baldwin's father, who owned a shoe business. When Roger Baldwin was searching for a career after college, Brandeis advised him to become a social worker, advice Baldwin followed. Baldwin, supra note 33, at 39, 40.

${ }^{734}$ Letter from Louis D. Brandeis to Robert M. La Follette (Nov. 24, 1918), reprinted in 4 LETTERS OF Louis D. BRANDEIS 364 (M. Urofsky \& D. Levy eds. 1975) [hereinafter cited as 4 BRANDEIS LETTERs]. These charges might have led to La Follette's expulsion from the Senate.

${ }^{705}$ Brandeis expressed happiness that "the burdens which long weighed so heavily" on La Follette were lifting and that he would be free to take his place of leadership "in the struggle for democracy in America." Id.

${ }_{736}$ Note by Louis D. Brandeis (Feb. 27, 1919) on letter from Elizabeth Walton to Louis D. Brandeis (Feb. 25, 1919) (Brandeis Papers, Louisville, supra note 744, Box WW 8-3b).

${ }^{757}$ Letter from Louis D. Brandeis to Susan Goldmark (Dec. 7, 1919), reprinted in 4 Branders LETTERS, supra note 754 , at 441 . 
in its disgraceful excess."758

C. Brandeis and the Unanimous Supreme Court Decisions in the Initial Wartime Cases

Despite his general concern for individual rights and the evidence he received that prosecutions under the Espionage Act, among other examples of widespread intolerance, threatened freedom of expression throughout the country, Brandeis joined the unanimous Supreme Court in the Selective Draft Law decisions and in the initial Espionage Act cases. Indeed, Brandeis wrote for the Court in Sugarman, ${ }^{758}$ the case which, together with Schenck, Frohwerk, and Debs, constituted the first group of Espionage Act opinions.

In a fascinating series of uninhibited conversations with Felix Frankfurter between 1921 and 1924, ${ }^{700}$ Brandeis commented on many aspects of his work as a Supreme Court Justice. Some of these conversations suggest reasons why he did not dissent in the first cases brought under the Selective Draft Law and the Espionage Act. In August 1921, Brandeis told Frankfurter:

I have never been quite happy about my concurrence in [the] Debs and Schenck cases. I had not then thought the issues of freedom of speech out-I thought at the subject, not through it. Not until I came to write the Pierce and Schaefer dissents did I understand it. ${ }^{761}$

This revealing admission, however satisfying to Brandeis as a subsequent justification, seems unconvincing as a full explanation. Brandeis may not have "thought through" free speech issues until he wrote his own dissents, but neither had he been as unsophisticated about them as his later comment to Frankfurter suggests. Brandeis had to decide to dissent before actually writing the opinions that forced him to analyze the meaning of freedom of expression in greater detail. Why then did he make this initial decision for the first time in Abrams rather than in Goldman, Kramer, Sugarman, or Debs?

7s8 Letter from Louis D. Brandeis to Learned Hand (Jan. 20, 1920), reprinted in 4 Brandeis LeTters, supra note 754, at 445.

76) Sugarman v. United States, 249 U.S. 182 (1919).

${ }^{260}$ Transcript of conversations between Louis D. Brandeis and Felix Frankfurter (Manuscript in Brandeis Papers, Harvard, supra note 702, Box 114, Folder 14) [hereinafter cited as Brandeis-Frankfurter Conversations]. Frankfurter took notes on these conversations. See F. Frankfurter, A Rbgistzr of His Papers in the Library of Congress 7 (1971).

${ }^{761}$ Brandeis-Frankfurter Conversations, supra note 760, at 23. 
As in determining the reasons for the shift in Holmes's approach between his first Espionage Act decisions and Abrams, it is impossible to answer this question with certainty. Some clues emerge from other portions of Brandeis's conversations with Frankfurter. Brandeis shared the consensus of the Justices that dissents should be suppressed whenever possible. In most cases, he told Frankfurter, "there is a good deal to be said for not having dissents-you want certainty and definiteness and it doesn't matter terribly how you decide as long as it is settled." Brandeis did not apply this general rule strictly in constitutional cases, where dissent has a "special function" because "nothing is ever settled." "762 Yet even in constitutional cases, there may be reasons to reject an inclination to dissent. Writing too many dissents can exasperate the other Justices, and "you may have a very important case of your own as to which you do not want to antagonize [others by dissenting] on a less important case." ${ }^{\text {"73 }}$ Brandeis took this consideration very seriously. In his first years on the Court, he kept elaborate statistics on total opinions, total dissents, how many Justices dissented, and how often each Justice was the sole dissenter. ${ }^{764}$ Brandeis also indicated to Frankfurter that the threat of a dissent could provoke the majority to meet the potential dissenter's major objections by modifying an initial draft. The result, even if less than ideal, could be worth the compromise. ${ }^{765}$ The pressure of other work could also deter a Justice from dissenting, even one as conscientious and efficient as Brandeis. ${ }^{766}$ Majority opinions assigned to Holmes presented additional problems because "Holmes shoots down so quickly and is disturbed if you hold him up." "As a result, "often there is not time to think out and . . . talk things over with him." "788 Brandeis emphasized to Frankfurter that "silence does not mean actual concurrence. . . . I sometimes endorse an opinion with which I do not agree, ' $I$ acquiesce." "769

Despite these general reservations about the wisdom of dissents, Brandeis's own statistics clearly demonstrate that he dis-

762 Id. at 16.

763 Id. at 18.

784 See statistics in Brandeis Papers, Harvard, supra note 702, Box 114, Folder 4 [hereinafter cited as Brandeis Statistics].

${ }_{763}$ See Brandeis-Frankfurter Conversations, supra note 760, at 9-10.

766 Id. at 26.

767 Id. at 18.

7*8 Id.; see id. at 26.

789 Id. at 8-9. 
sented during this period as much as any Justice on the Court. ${ }^{\text {770 }}$ Nonetheless, Brandeis joined a unanimous majority in the initial wartime cases, and he even wrote the Court's decision in Sugarman. He did not dissent in a first amendment case until he joined Holmes in Abrams.

Other explanations seem more plausible. Brandeis's support of the war might have impaired his ability to review with detachment the free speech claims of its opponents. Brandeis was an active proponent of Woodrow Wilson's war policies. Even while sitting on the Supreme Court he advised senior government officials, including Wilson himself, on the conduct of the war. ${ }^{771}$ Though Brandeis may have become concerned about the evidence of suppression that came to his attention during 1918 , much of it from people he respected, the hostility to the war expressed by the defendants in the Supreme Court cases may have seemed to Brandeis to be qualitatively different-and more threatening-from the examples provided by his friends and correspondents.

Even after the war, when Brandeis admitted to Frankfurter his regrets about his concurrences in Holmes's first Espionage Act decisions, he indicated that he still approved the convictions. His second thoughts were limited to the legal theory Holmes employed:

I would have placed the Debs case on the war power-instead of taking Holmes' line about "clear and present danger." Put it frankly on the war power-like [the] Hamilton case (251 U.S.) - and then the scope of espionage legislation would be confined to war. But in peace the protection against restriction of freedom of speech would be unabated. You might as well recognize that during a war-[here Frankfurter interrupted with the words “all bets are off']. Yes, all bets are off. But we would have a clear line to go on. I didn't know enough in the early cases to put it on that ground..$^{772}$

770 See Brandeis Statistics, supra note 764.

771 See A. MAson, supra note 724, at 518-27.

${ }^{772}$ Brandeis-Frankfurter Conversations, supra note 760, at 23. In Hamilton v. Kentucky Distilleries \& Warehouse Co., 251 U.S. 146 (1919), Brandeis, writing for a unanimous Court, upheld the War-Time Prohibition Act as a valid exercise of the war power. Although the statute was enacted after the Armistice with Germany, a peace treaty had not yet been signed and it could not be said "that the man power of the nation ha[d] been restored to a peace footing." Id. at 163. Asserting that "to Congress in the exercise of its powers, not least the war power upon which the very life of the nation depends, a wide latitude of discretion must be accorded," Brandeis concluded that the Act had not ceased to be valid because of "changed circumstances." Id; see also Gilbert v. Minnesota, 254 U.S. 325, 341-42 (1920) (Brandeis, J., dissenting) (state statute prohibiting interference with military enlistment void because interferes with Congress's exclusive war power); cf. Cover, supra note 706, at 
Brandeis probably never "thought through" the earlier cases when he wrote his later dissents. If he had, he probably would have come to the conclusion that none of the Espionage Act cases could be meaningfully distinguished on their facts. Abrams, Schaefer, ${ }^{773}$ Pierce, ${ }^{774}$ and Milwaukee Publishing Company, ${ }^{775}$ like Schenck, Sugarman, Frohwerk, and Debs, all involved similar language used by radicals before the end of the war. Brandeis's continued acceptance of the first convictions, even after his dissents in analogous cases, points to his prowar views as the determining influence when the Selective Draft Law and the initial Espionage Act cases were before the Court. Brandeis's subsequent suggestion of the war power as the doctrinal basis for affirming the convictions in Schenck and Debs underlines the importance of the war in his thinking about these cases.

\section{Brandeis and the Elaboration of Libertarian Doctrine}

Even if Brandeis had been less affected by his active support of the war, his conversations with Frankfurter reveal how difficult it would have been for him to dissent alone in cases of such importance and visibility, especially from decisions written by Holmes, his most likely ally. Whether Brandeis "acquiesced" in or actually agreed with Holmes's earlier opinions, by the date of the Abrams decision many of the factors that led Holmes to dissent could have had a similar impact on Brandeis, who always had been more sympathetic to the value of free speech. And when Brandeis first wrote his own dissents in 1920, he began to "think through," with substantial assistance from Chafee's scholarly writings, the legal issues associated with his libertarian attitudes. Beginning with Schaefer, Brandeis expanded the protection for speech introduced by Holmes in Abrams. Brandeis's first amendment opinions culminated with his concurrence in Whitney ${ }^{778}$ in 1927, when he combined a revitalized "clear and present danger" standard with the incitement approach advocated by Hand in Masses. The result was a level of protection for freedom of expression that was not exceeded by a majority of the Supreme Court until Brandenburg $v$.

375 n.95 (noting that Act's prohibition "bore only an indirect relation to the war effort"). 773 Schaefer v. United States, 251 U.S. 466 (1920).

774 Pierce v. United States, 252 U.S. 239 (1920).

776 United States ex rel. Milwaukee Social Democratic Publishing Co. v. Burlson, 255 U.S. 407 (1921).

${ }^{736}$ Whitney v. California, 274 U.S. 357, 372 (1927) (Brandeis, J., concurring). 
Ohio $^{777}$ in 1969.

1. Factual and Statutory Analysis. In his first amendment opinions, as in most of his writings and in marked contrast to Holmes, Brandeis grounded his conclusions on meticulous attention to factual detail. ${ }^{778}$ Brandeis particularly revealed this trait in Schaefer and Pierce, his initial dissents in Espionage Act cases. The year after he wrote these dissents Brandeis told Frankfurter that in the "Schaefer and Pierce cases I made up my mind I would put it all out, let the future know what we weren't allowed to say in the days of the war and following." "779 $\mathrm{He}$ accomplished this goal by thoroughly examining the antiwar publications in both cases and by relating them to the explicit language of the Espionage Act. $\mathrm{He}$ warned against analyzing portions of a document out of context ${ }^{780}$ and quoted at length from the publications which formed the basis for the defendants' convictions. ${ }^{781}$

The defendants in Schaefer were officers of small newspapers published in German in Philadelphia. ${ }^{782}$ They often reprinted and rewrote articles that had already appeared elsewhere. ${ }^{783}$ In his dissent, Brandeis analyzed four of the articles for which the defendants were convicted. ${ }^{784}$ An article reprinted from a Berlin newspaper, Brandeis observed, was similar to other reprints from the press of Germany circulated by patriotic societies in the United States "to arouse the American fighting spirit." He thought it inconceivable that the "coarse and heavy humor" of this article "could rationally be held to tend even remotely or indirectly to obstruct recruiting." ${ }^{385}$ Brandeis also claimed that the defendants were incorrectly convicted under the falsity provision of the Espionage Act. He pointed out that the government, instead of attempt-

777395 U.S. 444 (1969) (per curiam).

${ }^{778}$ Brandeis reported to Frankfurter that Holmes "highly approves the inquiry into and reference to facts as the basis of my opinions." Brandeis-Frankfurter Conversations, supra note 760 , at 14 . Brandeis apparently criticized Holmes for not paying enough attention to facts. Holmes wrote Laski that Brandeis "drove a harpoon into my midriff by saying it would be for the good of my soul to devote my next leisure to the study of some domain of fact." Letter from Oliver Wendell Holmes, Jr., to Harold Laski (May 18, 1919), reprinted in 1 Holmes-LASKI LETTERS, supra note 442, at 204.

279 Frankfurter-Brandeis Conversations, supra note 760, at 23.

780 Pierce, 252 U.S. at 256 (Brandeis, J., dissenting); Schaefer, 251 U.S. at 483-84 (Brandeis, J., dissenting).

${ }^{781}$ Pierce, 252 U.S. at 256-64; Schaefer, 251 U.S. at 484-85, 487, 488-92.

782251 U.S. at 468.

7 sos Id. at 486 (Brandeis, J., dissenting).

7o4 Brandeis limited his analysis to 4 of the 15 publications set forth in the indictment so that he would not "unduly prolong" his opinion. Id. at 484 .

jas Id. at 486. 
ing to prove the actual falsity of any article, generally demonstrated only that certain reprinted articles differed in some respect from their original form. According to the government, this variation itself constituted falsity ${ }^{788}$ Resorting to his legendary thoroughness, Brandeis discovered that one charge of falsification resulted from an error by the government translator or draftsman in reproducing the German original in the English indictment. ${ }^{787}$ Other claims of falsification consisted of the omission in a reprint of a single sentence from the original ${ }^{788}$ and a mistranslation of "breadlines" as "breadriots." "789

Brandeis emphasized that the Espionage Act punishes only those false statements made " "with intent to interfere with the operation or success of the military or naval forces of the United States or to promote the success of its enemies." "790 Such false statements could include misinformation about government finances, war preparations, or military operations. ${ }^{291}$ But most of the defendants' publications, Brandeis stressed, were not false, and the mistranslation of one word in a lengthy passage, even if considered a false report, could not possibly have interfered with the war effort. The other publications contained in the indictment, he added, "were likewise impotent to produce the evil against which the statute aimed." publications as false reports would "subject[] to new perils the constitutional liberty of the press."793

In Pierce, Brandeis maintained more explicitly than he had in Schaefer that the defendants' antiwar statements, alleged by the government to be false under the Espionage Act, were expressions of opinion whose accuracy could not be determined. He stressed that a statement or report could be punished as false only if it is "capable of being proved false in fact," is actually "proved to be false," and is "known by the defendant to be false when made or conveyed." Brandeis acknowledged that expressions of opinion could justify convictions under other clauses of the Espionage Act, but he insisted that "an opinion is not capable of being proved

${ }^{788}$ Id. at $486-87$.

787 Id. at 488.

78 Id. at 489 .

789 Id. at 492 .

700 Id. at 492 (quoting language of Espionage Act).

791 Id. at 492-93.

792 Id. at 493.

793 Id. at 494 . 
false in fact," "704 however "grossly unfair as an interpretation of facts or even wholly unfounded in fact."”gs

Brandeis, cleverly and with typical industry, found and quoted from the one prewar decision that supported his distinction between false facts and opinions. ${ }^{796}$ He pointed out that even historians, with the advantages of training and perspective, are unable to agree on the identity and relative importance of causes of a war. According to Brandeis, "the contributing causes cannot be subjected, like a chemical combination in a test tube, to qualitative and quantitative analysis so as to weigh and value the various elements . . . ."797 Laymen discussing contemporary wars, he implied, could not be expected to do better than professional historians. ${ }^{788}$ Indeed, Brandeis claimed that senators and congressmen debating the war resolution disagreed with President Wilson's justification for American participation and expressed many of the same views for which the defendants in Espionage Act cases were convicted. ${ }^{799}$ Statements alleging that the power and interests of capitalists produced the American intervention in World War I, Brandeis maintained, "were an interpretation and discussion of public facts of public interest." He added that "even the President's address, which set forth high moral grounds justifying our entry into the war, may not be accepted as establishing beyond a reasonable doubt that a statement ascribing a base motive was criminally false." ${ }^{\$ 800}$ Brandeis observed that Wilson had himself written before he became President that " $[t]$ he masters of the Government of the United States are the combined capitalists and manufacturers of the United States." "B01 He also pointed out that the defendants, as "mere distributors of the leaflet," could not be charged with actual knowledge of its contents and were therefore immune from punishment even if the contents could conceivably be deemed false. ${ }^{802}$

According to Brandeis, the intent of the leaflet that consti-

794252 U.S. at 255-56 (Brandeis, J., dissenting).

$700 \mathrm{Id}$. at 266.

${ }^{796}$ Id. at 267 (quoting American School of Magnetic Healing v. McAnnulty, 187 U.S. 94, 104 (1902) (claims by Christian Scientists are "mere matters of opinion upon subjects which are not capable of proof as to their falsity" and therefore cannot be deemed statutory frauds)); see Rabban, supra note 4, at 542 (discussing Magnetic Healing).

${ }^{707}$ Pierce, 252 U.S. at 267 (Brandeis, J., dissenting).

7os Id.

799 Id. at 267-69.

800 Id. at 269.

${ }^{802}$ Id. at 270-71 (quoting W. Wilson, The New Freedom 57 (1913)).

${ }^{302}$ Pierce, 252 U.S. at 270. 
tuted the evidence in Pierce was simply to promote socialism. ${ }^{803}$ He conceded that it contained "lurid and perhaps exaggerated" descriptions of the horrors of war and that its arguments might be "shallow and grossly unfair." should not be "construed as criminal incitement to disobey the existing law" merely "because the argument presented seems to those exercising judicial power to be unfair in its portrayal of existing evils, mistaken in its assumptions, unsound in reasoning or intemperate in language." would have precluded most Espionage Act convictions.

2. Extending the "Clear and Present Danger" Standard. Throughout his first amendment opinions, particularly in Schaefer and Whitney, Brandeis extended the protection of the "clear and present danger" test. In his dissent in Schaefer, he characterized this standard, announced by a "unanimous court" in Schenck, as a "rule of reason" whose correct application demanded "good judgment" and "calmness." Abrams, included the requirement of immediacy in his definition of "clear and present danger," a requirement that was missing from Holmes's opinion for a unanimous Court in Schenck. Brandeis stressed that the "clear and present danger" test precluded judging speech by its "remote or possible effect." actual origins of this approach, Brandeis cited Chafee's Freedom of Speech in War Time rather than any of Holmes's prior opinions. ${ }^{808}$

In Whitney, Brandeis completed the retrospective assimilation of Abrams into Schenck that Holmes had begun. While adopting almost the exact language Holmes used in restating "clear and present danger" in Abrams, Brandeis cited Schenck, Holmes's original and significantly different formulation. ${ }^{809}$ And after pointing out that the Supreme Court "has not yet fixed the standard by which to determine"810 the meaning of "clear and present danger," Brandeis tried to go beyond the "rule of reason" he announced in Schaefer. He developed the immediacy criterion, declaring that there could be no "clear and present danger" "unless the incidence

sos Id. at 271 .

804 Id. at 272.

sos Id. at 273.

${ }^{808}$ Schaefer, 251 U.S. at 482-83 (Brandeis, J., dissenting).

807 Id. at 486.

${ }^{803}$ Id. (citing Chafee, Harvard, supra note 2, at 963 and claiming that "this court has declared" what "Professor Chafee has shown").

${ }^{809}$ Whitney, 274 U.S. at 373 (Brandeis, J., concurring).

s10 Id. at 374. 
of the evil apprehended is so imminent that it may befall before there is opportunity for full discussion." More significantly, Brandeis added a new requirement of gravity. "Prohibition of free speech and assembly is a measure so stringent," he maintained, "that it would be inappropriate as the means of averting a relatively trivial harm to society."811 For example, he found it inconceivable that a statute could constitutionally punish advocacy of trespassing as a felony even if a case presented an imminent danger of an actual trespass. For Brandeis, the likelihood that speech will cause some violence or destruction of property does not make it unlawful unless there is "probability of serious injury to the State." 1212 In effect, Brandeis transformed "clear and present danger" into an exception to a general rule forbidding restrictions on free speech. ${ }^{813}$

3. Combining "Clear and Present Danger" with Incitement. As he strengthened the "clear and present danger" test, Brandeis combined it with Hand's direct incitement standard. In Schaefer, Brandeis focused attention on the "nature and possible effect of a writing." 114 Though he acknowledged that external evidence may sometimes be necessary to demonstrate circumstances giving a document "a particular significance or effect," he stressed that the government had not introduced any such evidence. Unlike Holmes in Frohwerk, who upheld the conviction on an admittedly weak record because he would not reexamine the strength of the government's evidence, Brandeis urged reversal in Schaefer because the "writings here in question must speak for themselves." Pierce, Brandeis again looked to "the nature of the words used and the circumstances under which they were used."816 Indeed, Brandeis concluded that the language of the leaflet, "far from counselling disobedience to the law, points to the hopelessness of protest."817 With respect to the surrounding circumstances, Brandeis stressed that the defendants did not begin distribution until a judge in another case involving the same leaflet had directed an

sil Id. at 377.

812 Id. at 378.

s13 In their conversations, Brandeis told Frankfurter that the "right to your education and to utter speech is fundamental except clear and present danger." Brandeis-Frankfurter Conversations, supra note 760, at 21; see Cover, supra note 706, at 381 (identifying "clear and present danger" test as "exception").

s14 251 U.S. at 483 (Brandeis, J., dissenting).

s1s Id. at 484 .

2182 U.S. at 271 (Brandeis, J., dissenting).

s12 Id. at 272. 
acquittal, ${ }^{818}$ and that they never circulated it to members of the armed forces..$^{\text {810 }}$

Brandeis cemented the combination of these two standards in Whitney. Citing Hand's decision in Masses, Chafee's book, and a decision by Amidon, ${ }^{\mathbf{8 2 0}}$ Brandeis conceded that "[e]very denunciation of existing law tends in some measure to increase the probability that there will be some violation of it." But Brandeis, developing the conclusions of these authorities, added that "even advocacy of violation, however reprehensible morally, is not a justification for denying free speech where the advocacy falls short of incitement and there is nothing to indicate that the advocacy would be immediately acted on." To prove the existence of a "clear and present danger," he required a showing "either that immediate serious violence was to be expected or was advocated, or that the past conduct furnished reason to believe that such advocacy was then contemplated." 821

Without the doctrinal confusion of Chafee's forced assimilation of Schenck and Masses, Brandeis's first amendment opinions in the 1920's, particularly his concurrence in Whitney, joined as alternative tests Hand's analysis of the content of language and a protective version of Holmes's focus on possible consequences. $\mathrm{He}$ thereby anticipated the current standard for free speech, announced by the Court in Brandenburg $v$. Ohio ${ }^{822}$ and subsequently reaffirmed. ${ }^{823}$

4. Theoretical Foundations. Like Chafee, Brandeis stressed the ideological underpinnings of the legal standards he espoused. He harnessed his meticulous attention to fact and his subtle reconstructions of the "clear and present danger" standard to a libertarian theory of the first amendment as a pillar of individual rights and democratic government. The result, the analytical and rhetorical brilliance of his first amendment opinions in the 1920's, has never been equalled, and Whitney, his most developed opinion, defies paraphrase.

Analysis of the first amendment provided a natural vehicle for

818 Id. at 271.

810 Id. at 273.

820274 U.S. at 376 n.3 (Brandeis, J., dissenting) (citing Masses, 244 F. at 540; United States v. Fontana 4-5 (D.N.D. 1918) (Interp. of War Stat. Bulletin 148); Z. ChareE, supra, note 2 , at 46-56, 174).

821 Whitney, 274 U.S. 376.

${ }^{822} 395$ U.S. 444 (1969) (per curiam). In Brandenburg, the two tests are concurrent and not alternative. See infra text accompanying notes 902-12 (discussing Brandenburg).

823 See, e.g., Hess v. Indiana, 414 U.S. 105, 108 (1973) (per curiam). 
Brandeis to express his fundamental values. Brandeis attributed to the leaders of the Revolutionary War and to the framers of the Constitution the personal qualities he most admired. He described them as "courageous, self-reliant men, with confidence in the power of free and fearless reasoning applied through the processes of popular government." ${ }^{824}$ Brandeis drew support for his defense of free speech from his confidence in rational thought. "It is the function of speech," he declared, "to free men from the bondage of irrational fears." Even "[f]ear of serious injury cannot alone justify suppression of free speech and assembly." As Brandeis pointed out, "[m]en feared witches and burnt women." makes "men free to develop their faculties," pose of government. "If there be time to expose through discussion the falsehood and fallacies, to avert the evil by the processes of education, the remedy to be applied is more speech, not enforced silence."

Brandeis believed that free speech provides personal "happiness," but, following Chafee and earlier scholars, he particularly stressed that "freedom to think as you will and to speak as you think are means indispensable to the discovery and spread of political truth" and thus to the proper functioning of democratic government. ${ }^{828}$ Repressing speech abridges the "fundamental right of free men to strive for better conditions through new legislation and new institutions." ${ }^{228}$ Indeed, Brandeis concluded that a citizen's exercise of free speech is a duty as well as a right because it is even "more important to the Nation than it is to himself." to Brandeis, the framers, expressing their faith "in the power of reason as applied through public discussion," ${ }^{\text {8s1 }}$ proposed the first amendment to "preserve the right of free speech both from suppression by tyrannous, well-meaning majorities and from abuse by irresponsible, fanatical minorities."

Just as Brandeis viewed the "frank expression of conflicting

ss Whitney, 274 U.S. at 377 (Brandeis, J., concurring).

${ }^{825} \mathrm{Id}$. at 376.

328 Id. at 375 .

$2 x 7$ Id. at 377 .

228 Id. at 375 .

828 Pierce, 252 U.S. at 273 (Brandeis, J., dissenting).

sso Gilbert, 254 U.S. at 338 (Brandeis, J., dissenting); see also Whitney, 274 U.S. at 375 (Brandeis, J., concurring) ("public discussion is a political duty").

ss1 Whitney, 274 U.S. at 375 (Brandeis, J., concurring).

ssz Schaefer, 251 U.S. at 482 (Brandeis, J., dissenting); see also Whitney, 274 U.S. at 376 (Brandeis, J., concurring) (first amendment protects against "the occasional tyrannies of governing majorities"). 
opinions" as providing "the greatest promise of wisdom in governmental action," so also he warned that "in suppression lies ordinarily the greatest peril."833 Claiming to speak for the framers, Brandeis asserted

that it is hazardous to discourage thought, hope and imagination; that fear breeds repression; that repression breeds hate; that hate menaces stable government; that the path of safety lies in the opportunity to discuss freely supposed grievances and proposed remedies; and that the fitting remedy for evil counsels is good ones. ${ }^{834}$

Brandeis acknowledged that a real emergency can justify the repression of speech when there is not time to "permit reliance upon the slower conquest of error by truth." of the evil apprehended is so imminent that it may befall before there is opportunity for full discussion"836 and so dangerous that it threatens "serious injury to the State," "837 Brandeis maintained that the proper deterrents to crime "are education and punishment for violations of the law, not abridgement of the rights of free speech and assembly."

5. Identifying Threats to Free Speech. Throughout these opinions, Brandeis chastised agencies of official authority that had suppressed speech during and after the war. Brandeis remarked in Schaefer that "powers assumed to have been conferred upon the postal authorities" had allowed serious curtailment of free speech. ${ }^{839} \mathrm{He}$ focused on this issue in Milwaukee Social Democratic Publishing Co., ${ }^{840}$ where the postmaster, as in Masses, had invoked the Espionage Act to declare an antiwar journal nonmailable. Brandeis worried that the Postmaster General could "become the universal censor of publications"841 and concluded that if the Constitution permits administrators to deny second-class mailing privileges through an act of official discretion, "there is little of

ss3 Gilbert, 254 U.S. at 338 (Brandeis, J., dissenting).

ss4 Whitney, 274 U.S. at 375 (Brandeis, J., concurring).

sss Gilbert, 254 U.S. at 338 (Brandeis, J., dissenting); see also Whitney, 274 U.S. at 377

(Brandeis, J., concurring).

8ss Whitney, 274 U.S. at 377 (Brandeis, J., concurring).

837 Id. at 378; see also id. at 373 (free speech may be restricted "in order to protect the State from destruction or from serious injury, political, economic or moral").

sss Id. at 378.

${ }^{\text {8s9 }}$ Schaefer, 251 U.S. at 494 (Brandeis, J., dissenting).

840 United States ex rel. Milwaukee Social Democratic Publishing Co. v. Burleson, 255

U.S. 407 (1921).

s41 Id. at 423 (Brandeis, J., dissenting). 
substance in our Bill of Rights and in every extension of governmental functions lurks a new danger to civil liberty." "842

Brandeis also criticized jury convictions and judicial silence in Espionage Act prosecutions. According to Brandeis, the jury in Schaefer convicted the defendant "not merely for disloyal acts but for a disloyal heart; provided only that the disloyal heart was evidenced by some utterance." 843 He warned that "an intolerant majority, swayed by passion or by fear, may be prone in the future, as it has often been in the past, to stamp as disloyal opinions with which it disagrees." ${ }^{244}$ Similarly, Brandeis maintained that the jury conviction in Pierce, by construing antiwar opinions as false statements of fact, effectively denied "small political parties freedom of criticism and of discussion in times when feelings run high and the questions involved are deemed fundamental.".445 Brandeis conceded in Schaefer that the jury has a wide field in which to exercise its judgment, but he emphasized that the trial judge must withdraw a case from a jury if no calm person could reasonably conclude that the "clear and present danger" standard had been met. If the trial judge fails to exercise this responsibility, Brandeis added, the appellate court must correct the error. ${ }^{846}$ Ironically, Brandeis, who clearly thought the convictions in Schaefer and Pierce could not be supported by the evidence, was not so sure in Whitney, where he found sufficient testimony establishing a conspiracy "to commit present serious crimes." ${ }^{477}$ As a result, Brandeis's most stirring defense of free speech took the form of a concurring opinion supporting a conviction under the California Syndicalism Act. ${ }^{848}$

${ }^{812}$ Id. at 436. According to Brandeis, "Congress may not through its postal police power put limitations upon the freedom of the press which if directly attempted would be unconstitutional." Id. at 430-31.

ss Schaefer, 251 U.S. at 493 (Brandeis, J., dissenting).

s4 Id. at 495. Justice Clarke concluded his separate dissent in Schaefer by disagreeing with both the majority decision and the Brandeis-Holmes dissent. According to Clarke, the case did not involve threats to "law and order" or to "freedom of the press." Id. at 501 (Clarke, J., dissenting). But he did agree with Brandeis and Holmes that a "flagrant mistrial" had occurred, and he criticized the majority for failing to exercise its power "to correct, in this calmer time, errors of law which would not have been committed but for the stress and strain of feeling prevailing in the early months of the late deplorable war." Id.

as Pierce, 252 U.S. at 269 (Brandeis, J., dissenting).

s46 Schaefer, 251 U.S. at 483 (Brandeis, J., dissenting); see also Pierce, 252 U.S. at 271 (Brandeis, J., dissenting) (judges may not, in "absence of evidence," permit jury findings of guilt).

s17 Whitney, 274 U.S. at 379 (Brandeis, J., concurring).

ss Id. at 372. The opinion that became Brandeis's concurrence in Whitney was originally drafted, see Brandeis Papers, Harvard, supra note 702, Box 44, Folder 10 (Oct. 1, 
Perhaps most importantly, Brandeis did not automatically defer to legislation declaring speech illegal. Brandeis criticized the Minnesota statute at issue in Gilbert, which he characterized as "an act to prevent teaching that the abolition of war is possible," because it restricted such speech whatever the circumstances, rather than "in a particular emergency, in order to avert a clear and present danger." ${ }^{849}$ Brandeis elaborated this point in Whitney. Responding to the majority's opinion in Gitlow, ${ }^{850}$ he admitted that a legislature may directly prohibit speech it deems dangerous. But Brandeis insisted that "the enactment of the statute cannot alone establish the facts which are essential to its validity." Whenever a litigant claims a violation of free speech, Brandeis maintained, legislation, even if sustained by a lower court, "creates merely a rebuttable presumption" of legality. This presumption can be overcome if, under the circumstances of a particular case, a danger is not sufficiently imminent or serious. ${ }^{852}$

6. Expanding Federal Jurisdiction Over Speech. Probably prompted by Chafee, Brandeis also took the lead on the postwar ${ }^{853}$

1926), as a dissent in a similar case, Ruthenberg $v$. Michigan. His original concurrence in Whitney referred to Ruthenberg, "decided this day," for its reasoning. Id. Shortly before these two cases were to be announced, however, Ruthenberg died, and the Supreme Court dismissed his case. Ruthenberg v. Michigan, 273 U.S. 782 (1927).

Brandeis's law clerk, James Landis, had compared Ruthenberg and Whitney in a covering letter enclosing a revised draft of the Ruthenberg dissent. Landis pointed out that both cases involved "the right of assembly" and statutes that "are practically analogous." But Landis also observed differences between their facts. "The advocacy in the Whitney case was more direct. The meeting was not secret; there was evidence to show Miss Whitney's active participation in the framing of the doctrines; the intent immediately to propagate these doctrines; the advocacy of them to persons thitherto unfamiliar with them." Some or all of these considerations apparently influenced Brandeis to concur in Whitney despite his dissent in Ruthenberg, although Landis himself maintained that in both cases "there is no advocacy of immediate acts of violence." Landis assumed that "the principles enunciated in the Ruthenberg dissent are sufficient to resolve the Whitney case, and that you will be limited to showing their applicability to the facts of the case." Letter from J.M. Landis to Louis D. Brandeis (Aug. 21, 1926) (Brandeis Papers, Harvard, supra note 702, Box 44, Folder 7); cf. Cover, supra note 706, at 384-85 (describing factual differences between Ruthenberg and Whitney).

849 Gilbert, 254 U.S. at 334 (Brandeis, J., dissenting).

${ }^{8 s 0}$ Gitlow v. New York, 268 U.S. 652 (1925) (Brandeis, J., dissenting); see supra text accompanying notes 709-13 (discussing Gitlow).

${ }^{831}$ Whitney, 274 U.S. at 374 (Brandeis, J., concurring).

${ }^{882}$ Id. at 379. Landis made many of these points in a memorandum to Brandeis on Ruthenberg v. Michigan, 273 U.S. 782 (1927). Memorandum from J.W. Landis to Louis D. Brandeis (Oct. 10, 1926) (Brandeis Papers, Harvard, supra note 702, Box 44, Folder 10); see supra note 848 (discussing Ruthenberg).

${ }^{8 s s}$ Dissenting from Justice Holmes's majority opinion in Patterson v. Colorado ex rel. Attorney General, 205 U.S. 454 (1907), Justice Harlan had maintained that prior to the fourteenth amendment "the rights of free speech and a free press" were already guaranteed 
Supreme Court in advocating expanded federal jurisdiction over free speech issues. Brandeis, the lone dissenter in Gilbert in 1920, relied on the supremacy of federal law to support his conclusion that the Minnesota sedition statute violated the first amendment. In addition, he suggested in Gilbert, ${ }^{854}$ and later declared in Whitney, ${ }^{855}$ that freedom of speech constitutes part of the substantive "liberty" protected against state deprivation by the due process clause of the fourteenth amendment.

Brandeis's comments on these issues in Gilbert apparently reflected Chafee's influence. Dean Acheson, who served as law clerk to Brandeis during the term that the Supreme Court decided Gilbert, wrote Chafee, his former law professor, to inform him that the Court was considering this case. Chafee responded, in a letter written less than a month before the Court released its opinion, by sending Acheson the page proofs of chapter two of Freedom of Speech. ${ }^{886}$ Chafee complained to Acheson that, except for one dissent in a state court opinion, he had "as yet got no one to agree with my constitutional argument that the state powers over opposition to war are no stronger than state power over intrastate railroad rates, so that when Congress acts, the states must drop out." Chafee pointed out that Gilbert raised the additional issue of "whether the 14th Amendment guarantees freedom of speech from state action" and observed that Holmes had declined to consider this issue in Fox $v$. Washington. ${ }^{85 z}$ Chafee questioned the practical advantages of relying on the fourteenth amendment to protect speech, even assuming judicial acceptance of the state action rationale. In view of the Supreme Court's earlier Espionage Act decisions, he saw no basis for thinking that it would find free speech "violated [in] any way" by the Minnesota statute. Chafee was more optimistic that the "nationalistic" Supreme Court "would not favor the way state legislation would and to some extent did block the discussion of policy of the federal government," although he

by the first amendment as "attributes of national citizenship." Id. at 464. The privileges and immunities clause of the fourteenth amendment, he added, extended these guarantees against state action. Id. Harlan closed his dissent by further declaring that free speech and a free press are liberties protected by the due process clause of the fourteenth amendment. Id. at 465. Harlan's dissent, however, constituted the sole exception to the prewar decisions by the Supreme Court resisting the incorporation of first amendment guarantees into the fourteenth amendment. See Rabban, supra note 4, at 525-26.

ss4 254 U.S. at 343 (Brandeis, J., dissenting).

sss 274 U.S. at 373 (Brandeis, J., concurring).

s66 Letter from Zechariah Chafee, Jr., to Dean Acheson (Nov. 20, 1920) (Brandeis Papers, Harvard, supra note 702, Box 5, Folder 12).

ss7 236 U.S. 273 (1915); see Rabban, supra note 4, at 534-36 (discussing Fox). 
thought this the weaker of his two arguments theoretically. ${ }^{858}$

Despite Acheson's own "rather fundamental doubts"858 about both of these arguments, Brandeis's dissent in Gilbert closely paralleled Chafee's letter to Acheson, which is contained in Brandeis's files. Brandeis rejected the view that the first amendment applies only to federal action and therefore cannot justify Supreme Court interference with a state statute upheld as a police measure by the state's highest court. "The state law," Brandeis reasoned, "affects directly the functions of the Federal Government." tained that freedom of speech about these functions is a "privilege and immunity" of national citizenship which states could not curtail even before the fourteenth amendment became law. ${ }^{861}$ Because the federal government has the "superior responsibility" for preserving government, it also has the "superior right" to determine whether the national interest requires the suppression of free speech about governmental affairs. ${ }^{862}$ The "exclusiveness" of this federal power, Brandeis stressed, "springs from the very roots of political sovereignty." statute was inconsistent with federal law both before and after Congress passed the Espionage Act. Before the Espionage Act, "Congress still permitted free discussion" about the advisability of enlistment, and the Espionage Act itself, unlike the Minnesota statute, "did not prohibit the teaching of any doctrine."

Although Brandeis based his dissent in Gilbert on the exclusive federal power to regulate discussion of federal functions, ${ }^{865}$ he

${ }^{838}$ Letter from Chafee to Acheson, supra note 856.

sss Memorandum from Dean Acheson to Louis D. Brandeis (Nov. 19, 1920) (Brandeis Papers, Harvard, supra note 702, Box 5, Folder 12).

${ }_{880}$ Gilbert, 254 U.S. at 336 (Brandeis, J., dissenting).

${ }^{881}$ Id. at 337.

${ }^{802}$ Id. at 338. Brandeis underlined this point by citing cases involving regulation of interstate commerce. Id. at 339 (citing Monongahela Navigation Co. v. United States, 148 U.S. 312,329 (1893); Kurtz v. Moffitt, 115 U.S. 487 (1885)).

${ }^{863}$ Id. at 342. "The States may not punish treason against the United States," Brandeis added while citing two early state court decisions, "although indirectly acts of treason may affect them vitally. No more may they arrogate to themselves authority to punish the teaching of pacifism which the legislature of Minnesota appears to have put into that category." Id. at 342-43 (citations omitted).

ses Id. at 340 .

${ }^{868}$ Cover usefully labels Brandeis's argument in Gilbert as a "kind of structural preemption." Cover, supra note 706, at 379. Yet I think Cover exaggerates when he writes: "To Brandeis, it is not potential disruption of the war that grounds preemption but disruption of the national deliberative political process ...." Id. at 380 . Brandeis was certainly concerned about the impact that suppression of speech would have on political life, but he grounded his preemption argument on the exclusive power of Congress to declare war. See, e.g., 254 U.S. at 336 ("[a]s an incident of its power to declare war," Congress.may "prohibit 
concluded his opinion with an impassioned plea for extending the substantive due process right of the fourteenth amendment beyond the "liberty to acquire and to enjoy property." Brandeis had difficulty believing that the constitutional guarantee of liberty, which the Supreme Court had repeatedly invoked to protect businessmen against restrictive legislation, "does not include liberty to teach, either in the privacy of the home or publicly, the doctrine of pacifism; so long, at least, as Congress has not declared that the public safety demands its suppression." ${ }^{\mathbf{8 6 8}}$ In Gitlow, ${ }^{\mathbf{8 6 7}}$ decided five years later, the full Court agreed that free speech is one of the fundamental liberties protected by the due process clause, and Brandeis later reinforced this holding in Whitney. "The power of the courts to strike down an offending law," he concluded, "is no less when the interests involved are not property rights, but the fundamental personal rights of free speech and assembly." "888

\section{Conclusion}

In order to promote libertarian values without acknowledging their own prior role in the restrictive first amendment tradition, Holmes and Brandeis followed Chafee's misconstruction of "clear and present danger," a phrase Holmes first used in Schenck to elaborate the "bad tendency" theory. Chafee reciprocated by incorrectly attributing to all of their opinions a uniform libertarian interpretation of the first amendment. He eventually accounted for the undeniably restrictive elements of the first Espionage Act deci-

interference by persuasion"); cf. id. at 340 (The Espionage Act "did not prohibit the teaching of any doctrine; it prohibited only certain tangible obstructions to the conduct of the existing war."). At times, Cover himself seems to qualify somewhat the exaggeration quoted above. "Brandeis argued," Cover states elsewhere in his article, "that exclusive national jurisdiction over the national functions of conscription and war required constitutional immunity from state interference with the flow of public deliberation necessary to informed legislation." Cover, supra, at 379.

sos Gilbert, 254 U.S. at 343 (Brandeis, J., dissenting).

867268 U.S. at 666 (majority), 672 (dissent).

s6s 274 U.S. at 374 (Brandeis, J., concurring). I agree with Cover that Brandeis, who opposed extensions of substantive due process, held back in Gilbert so that he could continue to resist its application in other contexts. As Cover points out, Gilbert is a "tour de force" precisely because Brandeis's position did not depend on substantive due process. Cover, supra note 706, at 380; see Gilbert, 254 U.S. at 343 (Brandeis, J., dissenting) (because state statute invalidly "interferes with federal functions and with the right of a citizen of the United States to discuss them, I see no occasion to consider whether it violates also the Fourteenth Amendment."). Only in Whitney did Brandeis concede the relevance of substantive due process and invoke it explicitly to protect free speech. See Cover, supra note 706, at 379 \& n.102. See generally Warren, The New "Liberty" Under the Fourteenth Amendment, 39 HARv. L. Rzv. 431, 455-58 (1926) (tracing emergence of "free speech" as "liberty" protected by the fourteenth amendment). 
sions by claiming that "Justice Holmes was biding his time until the Court should have before it a conviction so clearly wrong as to let him speak out his deepest thoughts about the First Amendment." Pinning his hopes on "clear and present danger," Chafee submerged the incitement standard Hand developed in Masses, the approach that Chafee himself preferred.870

While never matching the rhetoric of Holmes in Abrams or Brandeis in Whitney, the Supreme Court majority, after a long and uneven history, has apparently accepted, and in some ways moved beyond, the libertarian views advanced by scholars before World War I and by Hand, Chafee, Holmes, and Brandeis in the decade following the Espionage Act of 1917. Despite the heroic attempts of Chafee, Holmes, and Brandeis to promote libertarian doctrine through the "clear and present danger" standard, however, protective Supreme Court decisions have followed it only fitfully.

Three important decisions by Chief Justice Hughes in the 1930's opened a new era in the history of Supreme Court adjudication of free speech claims. Though rarely referring directly to the first amendment, Hughes, writing for a majority or for a unanimous court, protected speech in a variety of factual settings. ${ }^{871}$ Given the often tortured efforts of Chafee, Holmes, and Brandeis to promote "clear and present danger" as the legal formula for their libertarian values, it is ironic that the first Supreme Court decisions in which the majority actually protected speech never mentioned this language. Indeed, Hughes's constant reiteration of the distinction between legal speech and unlawful incitements ${ }^{872}$ is strikingly similar to Hand's analysis in Masses. It therefore appears that the forced assimilation by Chafee and Brandeis of the very different approaches of Hand and Holmes was based on a misplaced pragmatism. As it turned out, the "clear and present danger" test was not needed when the Supreme Court first accepted free speech claims.

From the late 1930's through the early 1950's, many Supreme Court opinions revived and expanded the scope of the "clear and

869 Z. Chafee, Free Speech in the United States 86 (1941).

${ }^{870}$ See supra text accompanying notes 580-605.

871 DeJonge v. Oregon, 299 U.S. 353 (1937) (reversing conviction for criminal syndicalism); Near v. Minnesota ex rel. Olsen, 283 U.S. 697, 697 (1931) (overturning statute permitting injunctions against "malicious, scandalous, and defamatory" publications); Stromberg v. California, 283 U.S. 359 (1931) (invalidating statute prohibiting display of red flag).

872 See, e.g., DeJonge v. Oregon, 299 U.S. 353, 365 (1937); Near v. Minnesota ex rel. Olsen, 283 U.S. 697, 713-15 (1931); Stromberg v. California, 283 U.S. 359, 359 (1931). 
present danger" test. Herndon v. Lowry, ${ }^{873}$ a 1937 decision reversing the conviction of a Communist Party organizer who had been attempting to recruit Southern blacks, marked the reappearance of "clear and present danger." majority, after unconvincingly attempting to distinguish Gitlow, ${ }^{875}$ applied a rigorous definition of the "clear and present danger" test to reject, for the first time in the history of Supreme Court adjudication, the "bad tendency" theory that had provided the rationale for most restrictive free speech decisions both before and after World War I. The opinion observed that the state statute defining insurrection, "as construed and applied" during the trial, did not "furnish a sufficiently ascertainable standard of guilt" to enable the judge and jury to "appraise the circumstances and character of the defendant's utterances or activities as begetting a clear and present danger of forcible obstruction of a particular state function."876 As a result, a speaker, "however peaceful his own intent," may be punished because a jury concludes that speech attacking social conditions or advocating a change in government "might, in the distant future" lead to the use of force. ${ }^{877}$ The Court rejected this "vague and indeterminate" standard of "dangerous tendency" as an unconstitutional "dragnet" that violates freedom of speech. ${ }^{878}$ Without explicitly acknowledging its doctrinal innovation, the Supreme Court majority in Herndon accepted as a constitutional rule the libertarian interpretation of "clear and present danger" initially set forth by Chafee in Freedom of Speech in War Time and promoted only by Holmes and Brandeis from Abrams through Whitney. ${ }^{879}$

In the fifteen years following Herndon, the Supreme Court majority often invoked the "clear and present danger" phrase to sustain free speech claims, often in very different contexts from its original use in cases involving subversive advocacy. The Court used this phrase to protect speakers punished for breaching the peace, ${ }^{880}$ contempt of court, ${ }^{881}$ peaceful picketing, ${ }^{882}$ solicitation of

\footnotetext{
o73 301 U.S. 242 (1937).

s74 Id. at 255.

975 Id. at 256-58.

878 Id. at 261.

877 Id. at 262.

s78 Id. at 263-64.

879 Ironically, Chafee himself was so concerned about the potential for racial warfare in the South that he thought the Supreme Court should have denied this free speech claim. See Prude, supra note 483, at 645.

sso Terminiello v. City of Chicago, 337 U.S. 1, 4 (1949); Cantwell v. Connecticut, 310
} U.S. 296, 309-11 (1940). 
union members, ${ }^{883}$ and failure to salute the American flag. ${ }^{884}$ Ignoring the majority's distinction in Gitlow, ${ }^{885}$ the Court applied the "clear and present danger" test to statutes punishing advocacy as well as to statutes prohibiting acts. Most strikingly, the Court twice used this language to reverse convictions of opponents of World War II whose appeals could easily have been denied according to the standards employed by Justice Holmes in Schenck, Frohwerk, and Debs. ${ }^{888}$

Although Supreme Court opinions after Herndon frequently relied on the "clear and present danger" test to protect free speech, the test did not become the prevailing standard of libertarian interpretation that Chafee had intended. The test was never consistently endorsed by a clear majority of the Supreme Court. ${ }^{887}$ Many majority decisions throughout this period upheld free speech claims without even mentioning "clear and present danger." deed, Justice Frankfurter, a close friend and associate of Justice Holmes, went out of his way to minimize its significance. Frankfurter stressed that Holmes never intended "clear and present danger" "to express a technical legal doctrine or to convey a formula for adjudicating cases. It was a literary phrase not to be distorted by being taken from its context." ${ }^{889}$ On the other hand, none of the Supreme Court cases that rejected free speech claims in the 1930s and 1940s referred to "clear and present danger" except in an occasional dissent. ${ }^{800}$ The phrase had become a useful, but never a necessary, route to a libertarian result. Restrictive decisions used other language.

At the height of the Cold War, the Supreme Court reverted to the restrictive interpretation of "clear and present danger" that

881 Craig v. Harney, 331 U.S. 367,378 (1947); Pennekamp v. Florida, 328 U.S. 331, 336, 347-50 (1946); Bridges v. California, 314 U.S. 252, 262-63, 273 (1941).

${ }_{882}$ Thornhill v. Alabama, 310 U.S. 88, 104-05 (1940).

88s Thomas v. Collins, 323 U.S. 516, 530, 536 (1945).

sst West Virginia State Bd. of Educ. v. Barnette, 319 U.S. 624, 633, 639 (1943); Taylor v. Mississippi, 319 U.S. 583, 589-90 (1943).

s8s See supra notes 709-13 and accompanying text.

s8s Hartzel v. United States, 322 U.S. 680, 687 (1944); Taylor v. Mississippi, 319 U.S. 583, 589-90 (1943).

887 See M. Shapiro, Freedom of Speech: The Supreme Court and Judicial Review 58 (1966); McKay, The Preference for Freedom, 34 N.Y.U. L. REv. 1182, 1208 (1959); Mendelson, Clear and Present Danger-From Schenck to Dennis, 52 Colum. L. Rev. 313, 320 (1952).

${ }^{888}$ See M. SHAPIRo, supra note 887, at 59-60; McKay, supra note 887, at 1207-08; Mendelson, supra note 887, at 324-26.

s89 Pennekamp v. Florida, 328 U.S. 331, 353 (1946) (Frankfurter, J., concurring).

890 Mendelson, supra note 887 , at 324 . 
marked its original formulation by Holmes in Schenck. In its 1951 decision in Feiner $v$. New York, ${ }^{891}$ the Supreme Court employed this phrase to deny a free speech claim. Dennis $v$. United States, ${ }^{892}$ decided later the same year, dramatically highlighted this reversion. Dennis is particularly significant because Learned Hand, who in the years immediately following World War I viewed his own decision in Masses as a compelling doctrinal alternative to Holmes's "clear and present danger" test, wrote the Second Circuit opinion in Dennis which the Supreme Court affirmed.

Upholding the conviction of eleven leaders of the Communist Party, Hand, in language quoted verbatim by Chief Justice Vinson in his plurality opinion for the Supreme Court, rephrased the "clear and present danger" test. According to Hand, judges must "ask whether the gravity of the 'evil,' discounted by its improbability, justifies such invasion of free speech as is necessary to avoid the danger." ${ }^{898}$ Unlike Brandeis in Whitney, who maintained that the gravity of the evil should be considered only after its imminence had been demonstrated, ${ }^{894}$ Hand "purposely substituted 'improbability' for 'remoteness" "\$8s and used gravity, not as an independent test, but as a "mutually interdependent" factor to be balanced against improbability. ${ }^{896}$ Justices Frankfurter and Jackson wrote separate concurrences in Dennis upholding the convictions while criticizing the "clear and present danger" test. ${ }^{\mathbf{8 9 7}}$ Justices Black and Douglas each dissented, claiming that the plurality misconstrued the meaning of "clear and present danger."

The Dennis case marked both the apex and the turning point of the Supreme Court's reliance on the "clear and present danger"

801340 U.S. 315, 320-21 (1951); cf. American Communications Ass'n v. Douds, 339 U.S. 382, 393-98 (1950) (rejecting application of "clear and present danger" test while upholding requirement that union officers sign "non-Communist" affidavit).

892341 U.S. 494 (1951).

${ }^{823} 183$ F.2d 201, 212 (2d Cir. 1950), quoted in 341 U.S. at 510.

s94 See 274 U.S. at 377-78 (Brandeis, J., concurring); cf. supra text accompanying notes 811-12, 835-38. Hand himself conceded in Dennis that "it would be uncandid to say" that Holmes's dissent in Gitlow "did not make the immediacy of the 'substantive evil' a condition of the unlawfulness of even direct incitement to rebellion." 183 F.2d at 208. Hand noted, however, that this dissent "also dwelt upon the improbability that the paltry efforts of the accused could effect their purposes within any period which need[s] to be reckoned with." Id.

s93 183 F.2d at 212. "Given the same probability," Hand explained, "it would be wholly irrational to condone future evils which we should prevent if they were immediate." Id. For Hand, immediacy was an important, but not an exclusive, measure of probability.

396 Id. at 209.

${ }^{897} 341$ U.S. at 570 (Jackson, J., concurring), 519, 542, 551 (Frankfurter, J., concurring).

s98 Id. at 585-90 (Douglas, J., dissenting), 579-80 (Black, J., dissenting). 
test. The phrase could no longer bear the pressure of the inconsistent interpretations placed on it by different Justices. And the opinions by Hand and Vinson made painfully clear to libertarians that "clear and present danger" was no longer a "one-way ticket" Court opinions occasionally cited this test, it never again recaptured the prominence it had achieved in the fifteen years between Herndon and Dennis. The Warren Court often resolved free speech issues through doctrines which allowed it to uphold free expression without focusing directly on the dividing line between protected and unprotected speech. ${ }^{800}$ Indeed, the Warren Court's decision not to apply the "clear and present danger" test in an important first amendment case struck one astute commentator as a "conceptual revolution." At the very least, Dennis and its aftermath signalled the failure of the attempt by Chafee, Holmes, and Brandeis to make "clear and present danger" the constitutional standard for libertarian values.

Yet this failure did not terminate the influence of the early civil libertarians on the evolution of modern Supreme Court doctrine. Prosecutions under the Smith Act after Dennis brought a renewed focus on the content of speech, the factor stressed by Hand in Masses but largely submerged in Supreme Court analysis during the intervening years. And the Warren Court's "clearest and most protective standard under the first amendment," 1969 decision in Brandenburg $v$. Ohio, ${ }^{903}$ seemed to join the most protective elements of the incitement and the "clear and present danger" standards as independent tests that must both be met before speech can be punished. ${ }^{.04}$ The incitement standard, while protecting advocacy short of incitement, did not preclude punishing incitements to future actions. The "clear and present danger" standard, as long as it retained its immediacy requirement, protected remote incitements but allowed the punishment even of ab-

s99 Mendelson, supra note 887, at 324 .

${ }^{900}$ See Greenawalt, Speech and Crime, 1980 Am. B. Found. Research J. 645, 721-22. See generally Gunther, Reflections on Robel: It's Not What the Court Did But the Way That It Did It, 20 Stan. L. REv. 1140 (1968).

${ }^{802}$ Kalven, supra note 521, at 214.

902 Gunther, supra note 14, at 754.

sos 395 U.S. 444 (1969) (per curiam).

sot Gunther, supra note 14, at 754-55, was the first to stress this protective combination. See also Emerson, First Amendment Doctrine and the Burger Court, 68 Calir. L. REv. 422, 445-46 (1980); Comment, Brandenberg v. Ohio: A Speech Test for All Seasons?, 43 U.

CHi. L. REv. 151, 159-60 (1975). 
stract advocacy if it produced a sufficient probability of harm. ${ }^{905}$ In Whitney, Brandeis combined these two standards to require either the advocacy or the likelihood of "immediate serious violence." Brandenburg went further by requiring both the advocacy and the likelihood of "imminent lawless action." Accor According to the Court in Brandenburg,

the constitutional guarantees of free speech and free press do not permit a State to forbid or proscribe advocacy of the use of force or of law violation except where such advocacy is directed to inciting or producing imminent lawless action and is likely to incite or produce such action. ${ }^{908}$

Subsequent decisions by the Burger Court have reaffirmed the Brandenburg test. ${ }^{908}$

\section{POSTSCRIPT}

In many respects, the Brandenburg standard remains uncertain. No language in the per curiam opinion elaborated the single sentence in which the Court announced its striking new standard. Indeed, because this standard was neither accompanied by any serious analysis nor necessary to the resolution of the case, one thoughtful commentator has speculated that the Supreme Court in Brandenburg might not have intended the literal meaning of its own language. ${ }^{910}$ Nor has the Court, even while relying on Bran-

${ }^{905}$ See Comment, supra note 904, at 159-60; see also Gunther, supra note 14, at 755.

274 U.S. at 376 (Brandeis, J., concurring); see supra text accompanying notes 820 21.

${ }^{902} 395$ U.S. at 447. I am indebted to Jamie Kalven for helping me refine my thinking on the relationship between Whitney and Brandenburg.

908395 U.S. at 447.

${ }^{809}$ See, e.g., Carey v. Population Servs. Int'l, 431 U.S. 678, 701 (1977) (advertisements for contraceptives, "whatever might be the case if [they] directly incited illicit sexual activity among the young," do not violate Brandenburg standard); Communist Party v. Whitcomb, 414 U.S. 441, 448 (1974) (lengthy quotation from Brandenburg to invalidate statute excluding from ballot any political party refusing to take oath that it does not advocate the forceful overthrow of government); Hess v. Indiana, 414 U.S. 105, 108 (1973) (per curiam) (statement during campus antiwar demonstration "at worst . . . amounted to nothing more than advocacy of illegal action at some indefinite future time"); Healy v. James, 408 U.S. 169, 188 (1972) (applying Brandenburg to overturn denial by college president of official recognition of local chapter of SDS); cf. Ratchford v. Gay Lib, 434 U.S. 1080, 1085 (1978) (Rehnquist, J., dissenting from denial of certiorari) (Court should decide whether campus meetings of "Gay Lib" organization violate Brandenburg standard by leading directly to violations of state sodomy statute). See generally Emerson, supra note 904, at 446; Greenawalt, supra note 900, at 726; Gunther, supra note 14, at 754 \& n.192; Comment, supra note 904, at 160-63.

10 Greenawalt, supra note 900 , at 650 . 
denburg, ever elaborated its meaning. Commentators question whether it can be applied outside the context of advocacy of illegal activity. ${ }^{911}$ And even within this context, the Supreme Court has not addressed important distinctions between different kinds of advocacy. For example, there are compelling reasons rooted in first amendment theory for affording more constitutional protection to "public ideological solicitation" than to "private nonideological solicitation." Advocating robbery or murder for private gain surely stands on a different constitutional footing than advocating principled resistance to politically unpopular government policies. Yet Brandenburg and its progeny have not found it necessary to consider either this basic distinction or a myriad of more subtle but nevertheless significant ones..$^{912}$

More generally, substantial doubts can be raised as to whether any constitutional standard, however protective its language, can protect free speech in times of crisis. During the two greatest threats to free speech in the twentieth century, the Supreme Court failed to uphold first amendment values. Restrictive Supreme Court decisions construing the Espionage Act of 1917 during the "Red Scare" following World War I and the Smith Act during the early 1950's, at the height of the virulent anti-Communism personified by Senator Joseph McCarthy, promote understandable skepticism about the ability of the judiciary to withstand periods of national hysteria. Frohwerk, Debs, Dennis, and even Schenck are generally and appropriately considered blemishes on the first amendment tradition. This historical record makes it tempting to attribute the apparently more protective language of the Brandenburg standard and its subsequent reiterations to a time of greater popular acceptance of freedom of expresson, perhaps produced by substantial support for or toleration of the civil rights and antiwar movements of the 1960's. It is easy to doubt the efficacy of this standard during possible future outbreaks of widespread hostility to dissenters.

\footnotetext{
911 See, e.g., id. at 785. See generally Van Alstyne, A Graphic Review of the Free Speech Clause, 70 CaLIF. L. REv. 107, 110, 150 (1982). One commentator has extended the applications of the Brandenburg standard to various institutional settings, Comment, supra note 904 , at 165-91, but even this limited extension has been criticized. See, e.g., Emerson, supra note 904, at 438; Greenawalt, supra note 900, at 782-83.

912 The phrases in quotations are borrowed from Greenawalt, supra note 900, at 748-62. Greenawalt's comprehensive article contains numerous useful refinements of the Brandenburg test based on a close analysis of first amendment principles. His analysis indicates how many important issues remain unresolved. Pages $647-53$ and $783-85$ provide an overview of Greenawalt's major themes and conclusions. Van Alstyne provocatively reviews an even broader range of potential distinctions. See Van Alstyne, supra note 911, at 139-42.
} 
The Supreme Court's failure to protect free speech during prior periods of crisis, however, can be attributed to the weaknesses of inherited legal standards as well as to judicial capitulation to national hysteria. Holmes's opinions in the first Espionage Act cases, and the majority decisions in free speech cases throughout the 1920's, continued to rely on the restrictive "bad tendency" theory that had characterized Supreme Court decisions in the generation before World War I. The "clear and present danger" test, although it had been used to reach protective results, originated in Holmes's antilibertarian Social Darwinism. Its restrictive implications were noticed almost immediately by Hand and Chafee, and its weaknesses as a general analytic standard were emphasized before Dennis by Justice Frankfurter ${ }^{913}$ and by eminent scholars such as Paul Freund,, ${ }^{114}$ Alexander Meiklejohn,, ${ }^{115}$ and Herbert Wechsler ${ }^{916}$ It is intriguing to consider whether the prior development of a more protective and less manipulable standard-the Brandenburg test, for example-might have produced different results in 1919 or 1951. And it is unclear whether the Brandenburg test, generally considered the most protective standard for free speech adjudication ever developed by the Supreme Court, ${ }^{217}$ will actually shield freedom of expression against future intolerance.

The Brandenburg test, by requiring that the content of language constitute incitement and that the likelihood of illegal action be imminent, has enormous potential. Its application would arguably have overturned convictions in all of the cases in which the Supreme Court, using different standards, upheld convictions for subversive advocacy. The history of free speech adjudication, however, suggests further refinements that would strengthen and reinforce the Brandenburg test. Defining incitement as urging specific criminal action would clarify any lingering ambiguity regarding the Supreme Court's overly subtle distinction between general advocacy of illegal action and advocacy of abstract doctrine. ${ }^{918}$ And im-

91s See, e.g., Pennekamp v. Florida, 328 U.S. at 353 (Frankfurter, J., concurring).

014 P. Freund, ON Understanding the Supreme Court 27 (1949).

915 A. MEIKLEJOHN, supra note 14 , at 28-50.

936 Wechsler, supra note 14, at 887, reprinted in SkLEctBd Essays on Constitutional LAw, supra note 14 , at 628,634 .

917 See, e.g., Greenawalt, supra note 900, at 723-24; Gunther, supra note 14, at 754-55; Kalven, supra note 14, at 236 n.6; Comment, supra note 904, at 159-60; see also Emerson, supra note 904 , at 437.

918 This distinction emerged from Justice Harlan's opinions in Yates v. United States, 354 U.S. 298, 318-27 (1957), Scales v. United States, 367 U.S. 203, 230-55 (1961), and Noto v. United States, 367 U.S. 290, 291-300 (1961). Harlan himself acknowledged that this distinction is "subtle and difficult to grasp." Yates, 354 U.S. at 326; see Wechsler, Jones \& 
minence, as Brandeis suggested in Whitney, should be found only when circumstances preclude rational thought, including further speech. The seriousness of the crime advocated and threatened, a factor identified by Holmes, Brandeis, and Hand, should also be weighed in determining the appropriate penalty for speech that meets the incitement and imminence standards.919

A proper allocation of responsibilities between judge and jury, moreover, would help insure the just administration of the Brandenburg standard. As Hand pointed out in his correspondence with Holmes and as Brandeis stressed throughout his first amendment opinions, ${ }^{920}$ trial judges should withhold cases from juries when the evidence cannot support a conviction under the appropriate standard, and appellate judges should overturn jury convictions that do not meet this standard. ${ }^{921}$ On the other hand, when the evidence can support a conviction, judges should not, as in Dennis, remove the determination of guilt or innocence from juries. ${ }^{\mathbf{9 2 2}}$ Free speech is best protected if jury convictions are a necessary, but not a sufficient, condition for punishment. This division of roles preserves the benefits of trial by jury as a check against official abuse of power while restraining the excesses of hostile majorities.

The specter of the Supreme Court's historical failure to safeguard dissenting speech in times of national hysteria haunts even these libertarian refinements of Brandenburg. Their constraints still leave substantial room for discretion and subjectivity. The fact that the Brandenburg standard has never been tested during a period of widespread intolerance exacerbates uncertainties about its power, even if its logic is conceded. It may be that "public ideological speech" can be sheltered from the vagaries of interpretation only by a standard protecting advocacy of illegal action unless a criminal act, or at least a physical attempt, actually occurs. ${ }^{923}$ Such

Korn, supra note 401, at 626-27 (Model Penal Code requires criminal solicitation be "specific" to distinguish it from "legitimate agitation of an extreme or inflammatory nature"); $c$. Greenawalt, supra note 900, at 758 (supporting distinction between criminal "urging to specific crimes" and protecting "mere advocacy of illegal acts").

919 See supra text accompanying notes 836-38.

920 See supra text accompanying notes 463,846 .

921 See Greenawalt, supra note 900, at 750, 757 n.413.

922 See Boudin, "Seditious Doctrines" and the "Clear and Present Danger" Rule (pt. 2), 38 VA. L. REv. 315, 351, 355-56 (1952) (determination of "clear and present danger" in Dennis should have been made by jury); $c f$. A. Hiss, In the CourT of Public OpInion 286 (1957) ("The jury, a strong safeguard against unpopular officials, is little or no protection in times of public stress.").

223 Theodore Schroeder, the key figure in the Free Speech League in the generation 
a rule, however, is unlikely to be accepted by a Supreme Court majority. Some variant of Brandenburg will probably remain the constitutional standard for the foreseeable future. Only judicial construction during the next "Red Scare" or "McCarthy period" will reveal the extent to which this relatively protective test can induce judges to uphold free speech values in times of crisis.

before World War I and the author of an extensive libertarian analysis of the first amendment, proposed such a test. See Rabban, supra note 4, at 576-78 (discussing Schroeder's proposed test); $c f$. id. at 560-61 (more general discussion of Schroeder). Justice Black apparently took a more libertarian position. He maintained that all discussion of public affairs should be protected even if it does incite to action. Yates v. United States, 354 U.S. 298, 340 (1957) (Black, J., dissenting). Greenawalt rejects the proposition that liability for speech "should be permitted to attach only if the proposed crime is actually committed," although he concedes the possibility that "encouragements of open crimes that do not threaten persons or property . . . should receive absolute protection." Greenawalt, supra note 900 , at 759-62. 